\title{
The Chemical Composition and Health-Promoting Effects of the Grewia Species-A Systematic Review and Meta-Analysis
}

\author{
Muhammad Qamar ${ }^{1, *}\left(\mathbb{D}\right.$, Saeed Akhtar ${ }^{1}$, Tariq Ismail ${ }^{1,2}{ }^{\oplus}$, Muqeet Wahid ${ }^{3}{ }^{\oplus}$, Ross T. Barnard ${ }^{4}(\mathbb{D}$, \\ Tuba Esatbeyoglu $5, *(1)$ and Zyta M. Ziora ${ }^{6, *}$ \\ 1 Institute of Food Science and Nutrition, Bahauddin Zakariya University, Multan 60800, Pakistan; \\ saeedbzu@yahoo.com (S.A.); ammarbintariq@yahoo.com (T.I.) \\ 2 Department of Food Technology, Engineering and Nutrition, Lund University, \\ P.O. Box 188, SE-221 00 Lund, Sweden \\ 3 Department of Pharmacy, Bahauddin Zakariya University, Multan 60800, Pakistan; muqeetsoomro@msn.com \\ 4 School of Chemistry and Molecular Biosciences, University of Queensland, Brisbane, QLD 4072, Australia; \\ rossbarnard@uq.edu.au \\ 5 Institute of Food Science and Human Nutrition, Gottfried Wilhelm Leibniz University Hannover, \\ Am Kleinen Felde 30, 30167 Hannover, Germany \\ 6 Institute for Molecular Bioscience, University of Queensland, Brisbane, QLD 4072, Australia \\ * Correspondence: Muhammad.qamar44@gmail.com (M.Q.); esatbeyoglu@lw.uni-hannover.de (T.E.); \\ Z.ZIORA@imb.uq.edu.au (Z.M.Z.)
}

Citation: Qamar, M.; Akhtar, S.; Ismail, T.; Wahid, M.; Barnard, R.T.; Esatbeyoglu, T.; Ziora, Z.M. The Chemical Composition and Health-Promoting Effects of the Grewia Species-A Systematic Review and Meta-Analysis. Nutrients 2021, 13 4565. https://doi.org/10.3390/ nu13124565

Academic Editors: Jean Christopher Chamcheu and Francesca Giampieri

Received: 27 October 2021

Accepted: 13 December 2021

Published: 20 December 2021

Publisher's Note: MDPI stays neutral with regard to jurisdictional claims in published maps and institutional affiliations.

Copyright: (c) 2021 by the authors Licensee MDPI, Basel, Switzerland. This article is an open access article distributed under the terms and conditions of the Creative Commons Attribution (CC BY) license (https:// creativecommons.org/licenses/by/ $4.0 /)$

\begin{abstract}
Globally grown and organoleptically appreciated Grewia species are known as sources of bioactive compounds that avert the risk of communicable and non-communicable diseases. Therefore, in recent years, the genus Grewia has attracted increasing scientific attention. This is the first systematic review which focusses primarily on the nutritional composition, phytochemical profile, pharmacological properties, and disease preventative role of Grewia species. The literature published from 1975 to 2021 was searched to retrieve relevant articles from databases such as Google Scholar, Scopus, PubMed, and Web of Science. Two independent reviewers carried out the screening, selection of articles, and data extraction. Of 815 references, 56 met our inclusion criteria. G. asiatica and G. optiva were the most frequently studied species. We found 167 chemical compounds from 12 Grewia species, allocated to 21 categories. Flavonoids represented $41.31 \%$ of the reported bioactive compounds, followed by protein and amino acids (10.7\%), fats and fatty acids $(9.58 \%)$, ash and minerals $(6.58 \%)$, and non-flavonoid polyphenols (5.96\%). Crude extracts, enriched with bioactive compounds, and isolated compounds from the Grewia species show antioxidant, anticancer, anti-inflammatory, antidiabetic, hepatoprotective/radioprotective, immunomodulatory, and sedative hypnotic potential. Moreover, antimicrobial properties, improvement in learning and memory deficits, and effectiveness against neurodegenerative ailments are also described within the reviewed article. Nowadays, the side effects of some synthetic drugs and therapies, and bottlenecks in the drug development pathway have directed the attention of researchers and pharmaceutical industries towards the development of new products that are safe, cost-effective, and readily available. However, the application of the Grewia species in pharmaceutical industries is still limited.
\end{abstract}

Keywords: phytochemicals; antioxidant; inflammation; cancer; diabetes; antimicrobial

\section{Introduction}

The increasing number of deaths associated with cardiovascular disease, diabetes, cancer, inflammation, and other physiological disorders has gained the attention of health experts, researchers, and policymakers, with a view to promote healthy eating practices. Fruits and vegetables possess phytochemicals and metabolites that exhibit anticancer and anti-inflammatory effects, owing to their ability to scavenge free radicals in living systems [1-3]. Among these, the Grewia species are rich in phytochemicals and are regarded as a promising niche in averting or ameliorating the aforementioned chronic ailments. There 
are about 159 species of Grewia that are grown in tropical and sub-tropical areas of Pakistan, India, China, Malaysia, South Africa, Australia, northern Thailand, and Nigeria. Fruits of some of the Grewia species are edible e.g., G. asiatica, G. optiva, G. mollis, G. occidentalis, and G. tenax [4].

Numerous species of this genus have been shown to possess a variety of ethnopharmacological applications, e.g., G. asiatica leaves have been reported to cure skin problems such as eczema, eruptions, inflammation, as well as asthma, bronchitis, colds, coughs, and sore throat. G. optiva is used as "folk" medicine in the treatment of dysentery, typhoid, diarrhea, fever, cough, and smallpox [4]. G. tiliaefolia has been widely used to cure jaundice, biliousness, dysentery, and the diseases of the blood [5]. The ethnomedicinal formulations of G. mollis include infusion, decoction, maceration, or mucilage from the leaves, roots, or stem bark [6]. G. hirsute has been conventionally used to treat several disease conditions, such as rheumatism, joint pain, cholera, diarrhea, and ulcers [7]. G. tenax has been reported to cure distress of the stomach and skin, intestinal infections, fever, diarrhea, dysentery, hepatic disorders, jaundice, and rheumatism and has been reported to have antibiotic properties [8]. The boiled leaves of G. microcos are traditionally used to improve digestion and are also used for colds, hepatitis, diarrhea, heat stroke, dyspepsia, typhoid fever, and syphilitic ulceration of the mouth [9].

The traditional uses are increasingly supported by recent scientific research wherein some species of this genus have now been confirmed to possess anticancer, anti-inflammatory, antinociceptive, antioxidant, hepatoprotective, antidiabetic, antimicrobial, antimalarial, and sedative-hypnotic properties. They are also reported to hold immunomodulatory potential, to ameliorate learning and memory deficits, and to be effective against neurodegenerative ailments [10-12]. Such effects are predominantly attributed to the synergistic effects of phenolics such as flavonoids (i.e., flavones, flavanones, isoflavonoids, flavanols, dihydroflavonols, tannins, anthocyanidins), triterpenes, alkaloids, and phytosterols that are abundantly available in these species [2,13-15].

The Grewia species are also considered to be one of the most nutritious foods, since they are high in fiber, vitamins, carbohydrates, protein, and minerals, all of which are essential for a healthy lifestyle. G. asiatica fruits are enjoyed by people of all ages and communities in Pakistan because of their exquisite taste and affordable cost. Fresh fruits are consumed raw, and soft drinks are also produced from them. Jams, pies, squashes, and chutneys are all made using the fruit [1]. In Sudan, rural peasants utilize G. tenax fruits as an iron supplement for anemic children. Nesha is a thin porridge made from millet flour and the pulp of the G. tenax fruits, which is then thickened with custard. This porridge is provided to pregnant and breastfeeding women to help them stay healthy and produce milk for their babies [8]. In Pakistan and India, G. optiva fruits are edible and have a pleasant acid taste. The leaves are rated as good fodder and the trees are heavily lopped for this purpose in the winter months when no other green fodder is usually available [4].

In view of the preceding observations, a thorough and systematic analysis of the nutrients and phytochemical composition of the Grewia species could assist in a better understanding of the role of this genus in human nutrition and health. This review intends to provide a broad view of this species, beyond the currently available reviews, and highlights future potential biological and pharmacological research on the wide range of phytochemicals found in this genus. Herein, we systematically evaluate the nutrient and bioactive composition of the Grewia species, including the reported concentrations of its bioactive components and related biological activities. Additionally, a bibliometric analysis was performed for the first time, all to encourage experts from underrepresented localities of the globe to initiate new studies.

\section{Materials and Methods}

\subsection{Literature Search and Methodology}

The present review on the genus Grewia was planned and conveyed following the statement of PRISMA 10 (Supplementary S1) and based on the systematic review approach 
adopted by Muka et al. [16]. Different bibliographic databases (PubMed, Scopus, Web of Science, Google Scholar) were explored (Supplementary S2) to screen fifty-six relevant scientific articles published between 1975 and 31 March 2021 (date of last search) (Figure 1). The search terms were related to the nutritional aspects, and the phytochemical and pharmacological profiling of the genus Grewia (e.g., "nutritional composition", "traditional medicinal uses of Grewia", "biological activities of genus Grewia", "phytochemical composition of Grewia", "antioxidant potential of Grewia", "anticancer analysis of Grewia", "in vitro and in vivo anti-inflammatory activities of Grewia", "anti-diabetic properties of Grewia").

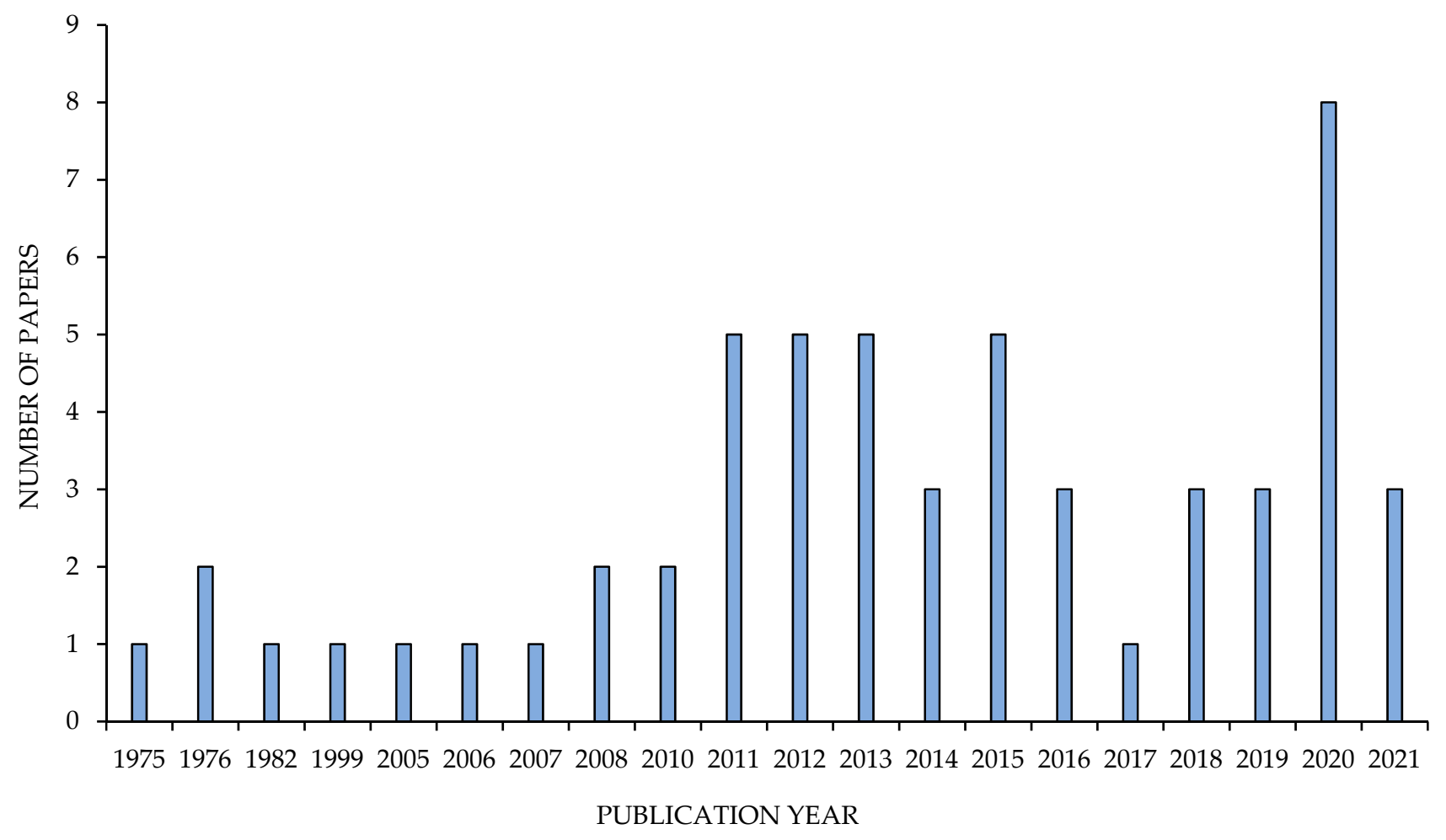

Figure 1. Fifty-Six articles (since 1975) retrieved with the search term "Grewia". Source: PubMed, Scopus, Web of Science, Google Scholar (last accessed 31 March 2021).

\subsection{Study Selection Criteria}

Articles were selected according to the criteria listed below:

i. Any parts of Grewia species, such as the pulp, skin, seeds, roots, bark or leaves were described;

ii. Evaluation of nutritional profiling, phytochemical composition/characterization, and pharmacological activities were provided.

Conference abstracts, letters to the editors, proceedings of conferences, literature reviews, meta-analyses, morphological studies, and product development experiments were excluded. To discover additional relevant articles, the reference lists of the included articles were checked (backward reference searching).

\subsection{Data Extraction}

The articles were sorted or screened by two reviewers including the first and fourth authors with respect to the provided information (Figure 2). 


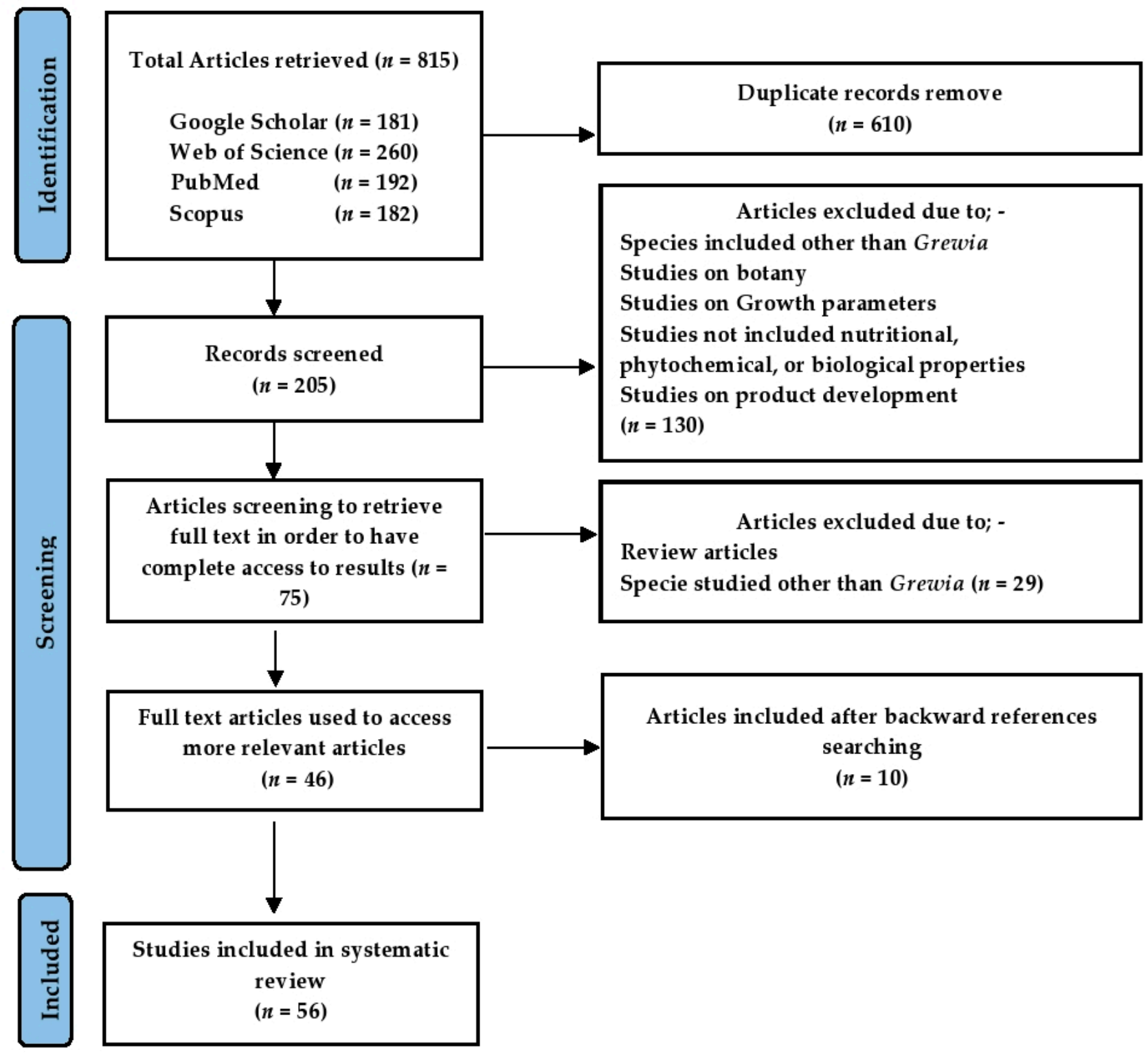

Figure 2. Flow diagram describing the study inclusion or exclusion criteria.

Articles focusing on the nutritional and phytochemical composition/identification/ characterization/quantification and the health-promoting impacts of the Grewia species, including the antioxidant, anti-inflammatory, antidiabetic, anticancer, antimicrobial and other biological activities were included in this review. The other key features were year of publication, species, type of solvent used for extraction, technique/method adopted for the identification of bioactive metabolites, and the parts of plants used in the experiment. Moreover, in vitro experiments and in vivo animal-based studies were also considered. Among all the eligible studies, eleven studies evaluated the proximate composition including carbohydrates, fat and fatty acids, protein and amino acids, fiber, ash and minerals, and vitamins. Nineteen studies evaluated the phytochemical composition including flavonoids, phenolic acids, terpenoids, phytosterols, carboxylic acid, hydroxycinnamic acid, sesquiterpenoids, hydroxycoumarins, fatty alcohol, phenols, xanthones, hydroxyquinols, and non-flavonoids. Eleven studies determined the antioxidant potential of Grewia using in vitro experiments. Six studies focused on in vitro anticancer properties using the 3-(4,5-dimethylthiazol-2-yl)-2,5-diphenyl-2H-tetrazolium bromide (MTT) assay against various cancer cell lines. In five articles, the anti-inflammatory properties of Grewia were analyzed; four of them were in vivo and one of them was in vitro. Eight studies evaluated 
the radioprotective/hepatoprotective potential of Grewia against radiation-induced thiobarbituric acid reactive substances (TBARS) and lipid peroxide production. Nine antimicrobial studies were conducted wherein four focused on antibacterial properties, two focused on antibacterial and antifungal activities, and two only studied antifungal capabilities. Seven articles evaluated antidiabetic potential wherein three studies used animal models, three used in vitro models, and one used a non-diabetic human model.

\subsection{Bibliometric Analysis}

Bibliometric analysis is a computational method for analyzing selected published research/review articles, as well as other related works on the subject that aims to attract experts from pharmaceutical industries paying close attention to the outcomes from this statistical method. The network maps were created based on research relationships between article authors, keywords in papers, journals in which publications are published, and organizations where research was performed (Figure 3). In the present systematic review, the analysis was performed on published data on various Grewia species. The co-authorship analysis was performed to investigate the interactions among scholars in relation to a research topic and a formal means for researchers to collaborate intellectually $[17,18]$.

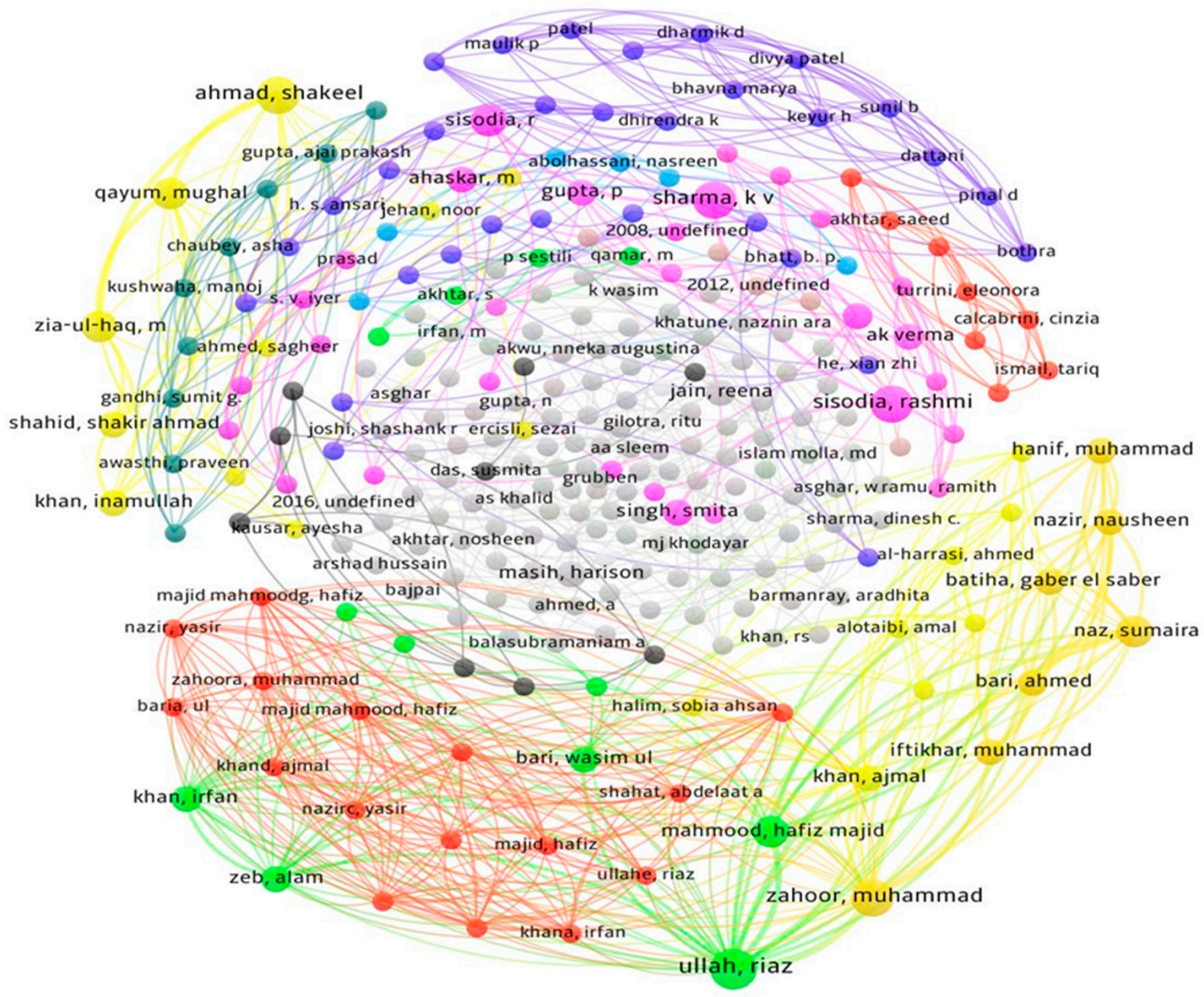

Figure 3. Network visualization map of the reported studies on various Grewia species. Clusters of different colors group authors belonging to the same region: the red, green, and yellow cluster represents authors from Pakistan, and the blue, pink, and grey cluster denotes authors from India. The few black nodes that can be seen in the picture represent South Africa and Botswana. Different clusters indicating authors from same region/country are due to the different years of publication. 
The goal was to create a network model that could describe the interactions between researchers from various areas of the world. For this purpose, relevant articles were found in the Mendeley database using the multiple key terms given in Section 2.1. Importantly, research articles were selected based on their publication year between 1975 and 2021 to provide the scope of research on the Grewia species during the last 50 years. A network visualization map was constructed based on this refined list, using VOS viewer software version 1.6.16 (available online: www.vosviewer.com, accessed on 5 November 2021) [19] for bibliometric analysis. For the study, a supported RIS file type was uploaded in the software. The type of analysis selected was "co-authors", the unit of analysis was "authors", the counting method was "full counting", and the maximum number per author selected was 25. In co-authorship networks, nodes represent authors, organizations, or countries, which are connected when they share the authorship of a paper, and these insights can be used to justify and encourage new studies among experts from underrepresented localities [20].

\section{Results}

In general, 167 chemical compounds from 12 Grewia species included in the study, allocated to 21 categories were found (Table 1). Flavonoids represented $41.9 \%$ of the reported bioactive compounds, followed by protein and amino acids $(10.9 \%)$, fats and fatty acids $(9.72 \%)$, ash and minerals $(6.67 \%)$, non-flavonoid polyphenols $(6.05 \%)$, triterpenes $(4.86 \%)$, phenolic acids (4.79\%), vitamins (3.03\%), carboxylic acids $(3.03 \%)$, and all other categories were below $2 \%$ of the total reported compounds (Figure 4). Of the 167 reported compounds, information on concentrations was available for 114 (68.3\%) of them, grouped in 9 categories. The information on concentration was not available for 53 compounds (31.6\%) grouped in 12 categories. Moreover, Table 1 also presents the compounds according to the parts of the plant in which they were reported. A total of 15 categories were studied in fruit, 6 in seeds, 8 in leaves, 4 in stem bark, 6 in roots, and 3 in flowers.

Concerning the methods used to identify and quantify the phytochemicals, we extracted information on the solvent or extract used to analyze every compound and the techniques used to identify or quantify them. As shown in Table 1, a wide variety of extracts/solvents and techniques were reported in the literature. In detail, $25.2 \%$ of the compounds were extracted with methanol in six studies [14,21-25], 47.8\% with acidified methanol in two studies [13,26], 11.7\% with water in two studies [2,27], 5.04\% with 50\% methanol in one study [24], 4.20\% with petroleum ether in one study [28], 3.36\% with chloroform in two studies [15,29], 2.52\% with ethyl acetate in one study [2], 1.68\% with aqueous acetone in one study [30], and 1.68\% with $80 \%$ methanol in one study [8]. Mass spectrometry was the most commonly employed technique for the identification of bioactive compounds (81.5\%) wherein one study used ESI-MS/MS, one used LC-QToF-MS, one used GC-MS, and two used NMR spectroscopy. Secondly, liquid chromatography was used for the identification of bioactive compounds $(11.7 \%)$, two studies employed HPLC using a diode array detector and in one article TLC was used, and information was not available for $6.70 \%$ of them. 


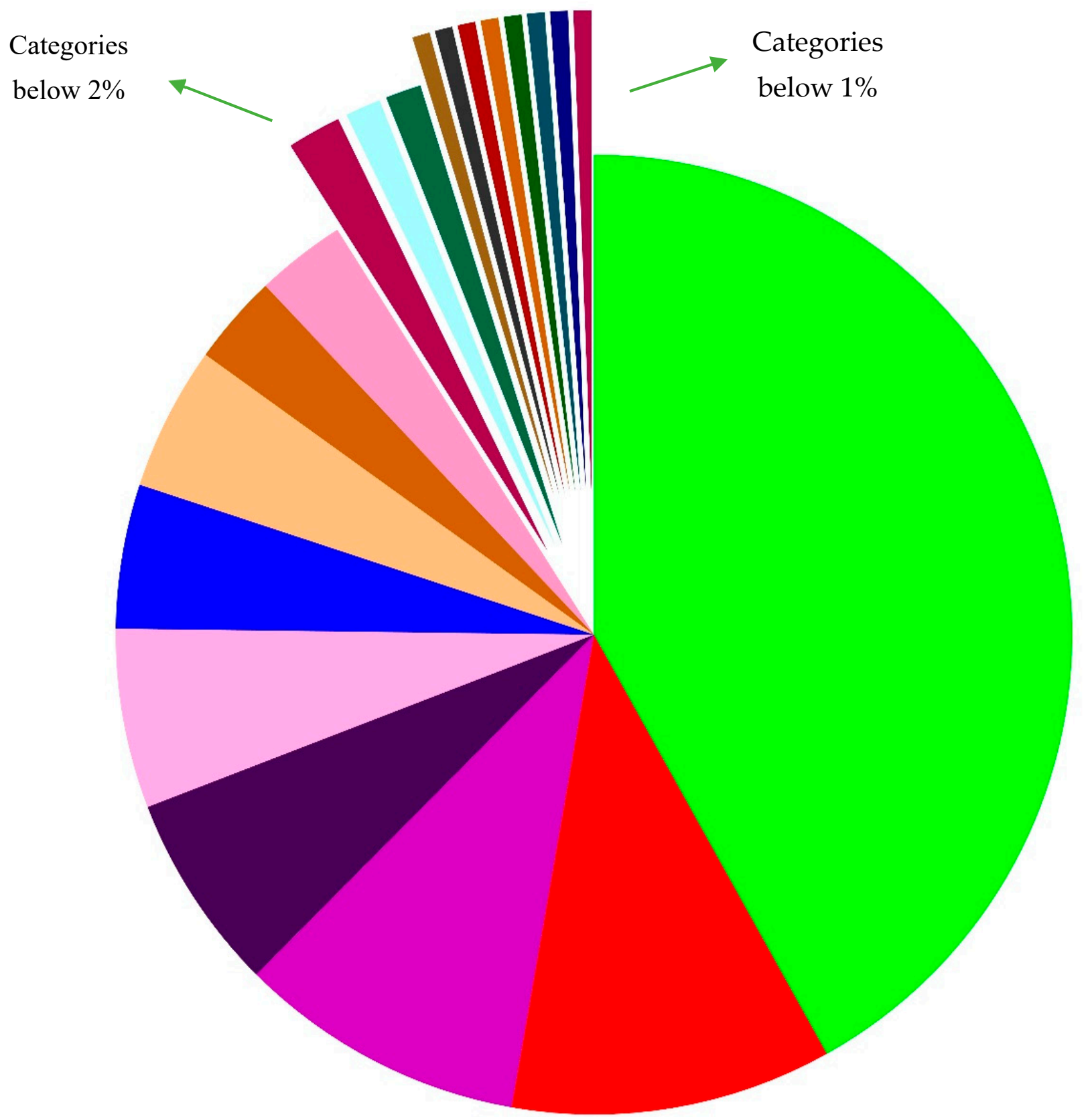

- 41.91\% Flavonoids

- $10.85 \%$ Protien and amino acids

- $9.72 \%$ Fat and fatty acids

- $6.05 \%$ Non flavonids polyphenols

- $4.86 \%$ Terpenes

- $6.67 \%$ Ash and mineral
- $4.86 \%$ Phenolic acid

- $3.03 \%$ Vitamins

$=3.03 \%$ Carboxylic acid

- $1.82 \%$ Phytosterol

$=1.21 \%$ Hydroxycinnamic acid

- $1.21 \%$ Sesquiterpenoid
- $0.60 \%$ Fatty alcohol

- $0.60 \%$ Phenol

- $0.60 \%$ Xanthone

- $0.60 \%$ Hydroxyquinols

- $0.60 \%$ Fiber

- $0.60 \%$ Carbohydrate

- $0.60 \%$ 7-Hydroxycoumarins

Figure 4. Percentage of primary and secondary metabolites in the Grewia species. 
Table 1. Proximate composition and the phytochemicals identified in various Grewia species from 1975 to 2021.

\begin{tabular}{|c|c|c|c|c|c|}
\hline Serial Number & Primary Metabolites & Species & Plant Part & Concentration (Dry Weight) & References \\
\hline \multicolumn{6}{|c|}{ Carbohydrates } \\
\hline 1 & Carbohydrates & G. asiatica & Fruits & $21.1 \%$ & [31] \\
\hline 1 & Carbohydrates & G. asiatica & Seeds & $39.7 \%$ & [33] \\
\hline 1 & Carbohydrates & G. tenax & Fruits & $66.0 \%$ & [34] \\
\hline 1 & Carbohydrates & G. tenax & Leaves & $28.6 \%$ & [32] \\
\hline 1 & Carbohydrates & G. tenax & Seeds & $66.5 \%$ & [35] \\
\hline 1 & Carbohydrates & G. flavescence & Fruits & $75.0 \%$ & [34] \\
\hline 1 & Carbohydrates & G. villosa & Fruits & $84.0 \%$ & {$[34]$} \\
\hline 1 & Carbohydrates & G. villosa & Leaves & $33.8 \%$ & [32] \\
\hline 1 & Carbohydrates & G. tilifolia & Leaves & $40.1 \%$ & [32] \\
\hline 1 & Carbohydrates & G. nervosa & Leaves & $38.6 \%$ & [32] \\
\hline \multicolumn{6}{|c|}{ Fat and fatty acids } \\
\hline 2 & Fat & G. asiatica & Leaves & $2.60 \%$ & [32] \\
\hline 2 & Fat & G. asiatica & Seeds & $11.1 \%$ & [33] \\
\hline 2 & Fat & G. tenax & Fruits & $1.70 \%$ & [34] \\
\hline 2 & Fat & G. tenax & Leaves & $3.64 \%$ & [32] \\
\hline 2 & Fat & G. tenax & Seeds & $0.81 \%$ & [35] \\
\hline 2 & Fat & G. flavescence & Fruits & $1.30 \%$ & [34] \\
\hline 2 & Fat & G. villosa & Fruits & $1.50 \%$ & [34] \\
\hline 2 & Fat & G. villosa & Leaves & $3.38 \%$ & [32] \\
\hline 2 & Fat & G. tilifolia & Leaves & $3.32 \%$ & [32] \\
\hline 2 & Fat & G. nervosa & Leaves & $3.86 \%$ & [32] \\
\hline 3 & Oleic acid & G. asiatica & Seeds & $16.3 \%$ & [33] \\
\hline
\end{tabular}


Table 1. Cont.

\begin{tabular}{|c|c|c|c|c|c|}
\hline 3 & Oleic acid & G. bicolor & Seeds & $19.3 \%$ & [36] \\
\hline 4 & Linoleic acid & G. asiatica & Seeds & $60.1 \%$ & [33] \\
\hline 4 & Linoleic acid & G. bicolor & Seeds & $53.2 \%$ & [36] \\
\hline 6 & Palmitic acid & G. asiatica & Seeds & $12.1 \%$ & [33] \\
\hline 6 & Palmitic acid & G. bicolor & Seeds & $11.4 \%$ & [36] \\
\hline 7 & Stearic acid & G. asiatica & Seeds & $5.01 \%$ & [33] \\
\hline 7 & Stearic acid & G. bicolor & Seeds & $5.77 \%$ & [36] \\
\hline 8 & Margaric acid & G. asiatica & Seeds & $0.14 \%$ & [33] \\
\hline 9 & Myristic acid & G. asiatica & Seeds & $0.41 \%$ & [33] \\
\hline 10 & Behenic acid & G. asiatica & Seeds & $0.22 \%$ & [33] \\
\hline 11 & Linolenic acid & G. asiatica & Seeds & $2.55 \%$ & [33] \\
\hline 12 & Dihydro malvalic acid & G. asiatica & Seeds & $0.54 \%$ & [33] \\
\hline 13 & Dihydro sterculic acid & G. asiatica & Seeds & $0.65 \%$ & [33] \\
\hline 15 & Sterculic acid & G. asiatica & Seeds & $0.89 \%$ & [33] \\
\hline 16 & Docosanoic acid & G. optiva & & Not evaluated & [25] \\
\hline 17 & Octadecadienoic acid & G. microcos & & Not evaluated & {$[37]$} \\
\hline \multicolumn{6}{|c|}{ Protein and amino acids } \\
\hline 18 & Protein & G. asiatica & Fruits & $1.57 \% \mathrm{FW}$ & [31] \\
\hline 18 & Protein & G. asiatica & Leaves & $17.5 \%$ & [32] \\
\hline 18 & Protein & G. asiatica & Seeds & $17.4 \%$ & [33] \\
\hline 18 & Protein & G. tenax & Fruits & $7.70 \%$ & [34] \\
\hline 18 & Protein & G. tenax & Leaves & $18.9 \%$ & [32] \\
\hline 18 & Protein & G. tenax & Seeds & $7.50 \%$ & [35] \\
\hline
\end{tabular}


Table 1. Cont.

\begin{tabular}{|c|c|c|c|c|c|}
\hline 18 & Protein & G. flavescence & Fruits & $8.70 \%$ & [34] \\
\hline 18 & Protein & G. villosa & Fruits & $6.70 \%$ & [34] \\
\hline 18 & Protein & G. villosa & Leaves & $18.8 \%$ & [32] \\
\hline 18 & Protein & G. nervosa & Leaves & $12.9 \%$ & [32] \\
\hline 19 & Aspartic acid & G. asiatica & Seeds & $19.1 \%$ & [33] \\
\hline 20 & Valine & G. asiatica & Seeds & $13.0 \%$ & [33] \\
\hline 21 & Leucine & G. asiatica & Seeds & $11.0 \%$ & [33] \\
\hline 22 & Glutamic acid & G. asiatica & Seeds & $11.0 \%$ & [33] \\
\hline 23 & Isoleucine & G. asiatica & Seeds & $8.01 \%$ & [33] \\
\hline 24 & Phenylalanine & G. asiatica & Seeds & $7.00 \%$ & [33] \\
\hline 25 & Threonine & G. asiatica & Seeds & $4.06 \%$ & [33] \\
\hline 26 & Proline & G. asiatica & Seeds & $3.01 \%$ & [33] \\
\hline 27 & Tyrosine & G. asiatica & Seeds & $3.00 \%$ & [33] \\
\hline 29 & Alanine & G. asiatica & Seeds & $1.03 \%$ & [33] \\
\hline 30 & Arginine & G. asiatica & Seeds & $2.07 \%$ & [33] \\
\hline 31 & Tryptophan & G. asiatica & Seeds & $1.00 \%$ & [33] \\
\hline 32 & Lysine & G. asiatica & Seeds & $2.00 \%$ & [33] \\
\hline 33 & Histidine & G. asiatica & Seeds & $2.02 \%$ & [33] \\
\hline 34 & Glycine & G. asiatica & Seeds & $1.02 \%$ & [33] \\
\hline 35 & Serine & G. asiatica & Seeds & $4.02 \%$ & [33] \\
\hline \multicolumn{6}{|c|}{ Fiber } \\
\hline 36 & Fiber & G. asiatica & Fruits & $5.53 \% \mathrm{FW}$ & [31] \\
\hline 36 & Fiber & G. asiatica & Leaves & $38.3 \%$ & [32] \\
\hline
\end{tabular}


Table 1. Cont.

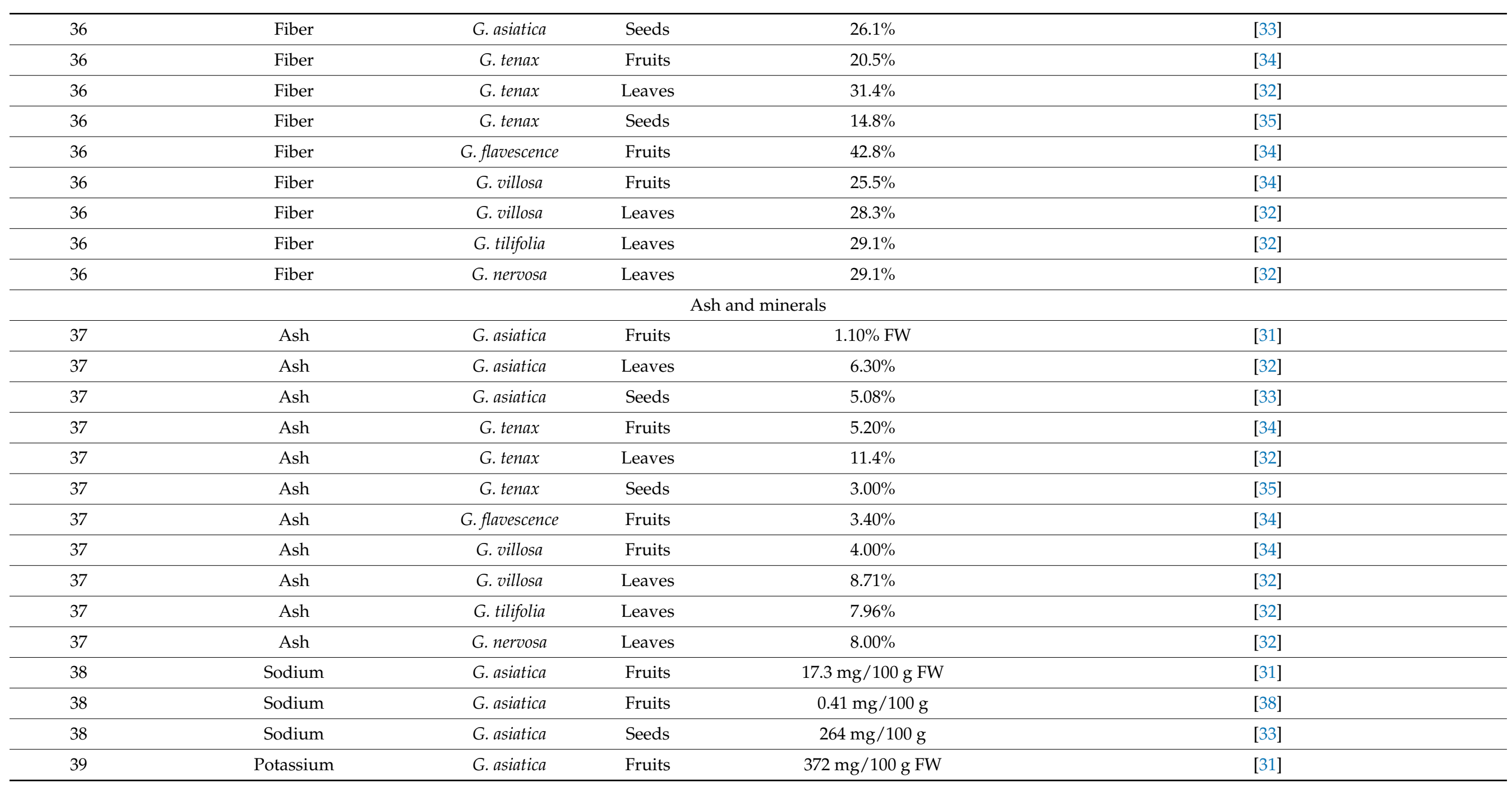


Table 1. Cont.

\begin{tabular}{|c|c|c|c|c|c|}
\hline 39 & Potassium & G. asiatica & Fruits & $0.39 \mathrm{mg} / 100 \mathrm{~g}$ & [38] \\
\hline 39 & Potassium & G. tenax & Fruits & $817 \mathrm{mg} / 100 \mathrm{~g}$ & [34] \\
\hline 39 & Potassium & G. flavescence & Fruits & $877 \mathrm{mg} / 100 \mathrm{~g}$ & [34] \\
\hline 39 & Potassium & G. villosa & Fruits & $966 \mathrm{mg} / 100 \mathrm{~g}$ & [34] \\
\hline 40 & Calcium & G. asiatica & Fruits & 136 mg 100 g FW & [31] \\
\hline 40 & Calcium & G. tenax & Fruits & $790 \mathrm{mg} / 100 \mathrm{~g}$ & [34] \\
\hline 40 & Calcium & G. flavescence & Fruits & $269 \mathrm{mg} / 100 \mathrm{~g}$ & [34] \\
\hline 40 & Calcium & G. villosa & Fruits & $536 \mathrm{mg} / 100 \mathrm{~g}$ & [34] \\
\hline 40 & Calcium & G. asiatica & Seeds & $820 \mathrm{mg} / 100 \mathrm{~g}$ & [33] \\
\hline 41 & Phosphorus & G. asiatica & Fruits & $24.2 \mathrm{mg} / 100 \mathrm{~g} \mathrm{FW}$ & [31] \\
\hline 41 & Phosphorus & G. asiatica & Seeds & $294 \mathrm{mg} / 100 \mathrm{~g}$ & [33] \\
\hline 42 & Manganese & G. asiatica & Fruits & $1.08 \mathrm{mg} / 100 \mathrm{~g}$ & [38] \\
\hline 42 & Manganese & G. tenax & Fruits & $5.10 \mathrm{mg} / 100 \mathrm{~g}$ & [34] \\
\hline 42 & Manganese & G. flavescence & Fruits & $0.1 \mathrm{mg} / 100 \mathrm{~g}$ & [34] \\
\hline 42 & Manganese & G. asiatica & Seeds & $1.03 \mathrm{mg} / 100 \mathrm{~g}$ & [33] \\
\hline 43 & Copper & G. asiatica & Fruits & $16 \mu \mathrm{g} / 100 \mathrm{~g}$ & [39] \\
\hline 43 & Copper & G. tenax & Fruits & $1.5 \mathrm{mg} / 100 \mathrm{~g}$ & [34] \\
\hline 43 & Copper & G. flavescence & Fruits & $1.1 \mathrm{mg} / 100 \mathrm{~g}$ & [34] \\
\hline 43 & Copper & G. villosa & Fruits & $1.2 \mathrm{mg} / 100 \mathrm{~g}$ & [34] \\
\hline 43 & Copper & G. asiatica & Seeds & $1.09 \mathrm{mg} / 100 \mathrm{~g}$ & [33] \\
\hline 44 & Iron & G. asiatica & Fruits & $1695 \mu \mathrm{g} / 100 \mathrm{~g}$ & [39] \\
\hline 44 & Iron & G. tenax & Fruits & $20.8 \mathrm{mg} / 100 \mathrm{~g}$ & [34] \\
\hline 44 & Iron & G. flavescence & Fruits & $26.9 \mathrm{mg} / 100 \mathrm{~g}$ & [34] \\
\hline 44 & Iron & G. villosa & Fruits & $29.6 \mathrm{mg} / 100 \mathrm{~g}$ & [34] \\
\hline
\end{tabular}


Table 1. Cont.

\begin{tabular}{|c|c|c|c|c|c|c|c|}
\hline 44 & Iron & G. asiatica & Seeds & $27.10 \mathrm{mg} / 100 \mathrm{~g}$ & & [33] & \\
\hline 45 & Zinc & G. asiatica & Fruits & $58 \mu \mathrm{g} / 100 \mathrm{~g}$ & & [39] & \\
\hline 45 & Zinc & G. tenax & Fruits & $1.9 \mathrm{mg} / 100 \mathrm{~g}$ & & [34] & \\
\hline 45 & Zinc & G. villosa & Fruits & $1.5 \mathrm{mg} / 100 \mathrm{~g}$ & & {$[34]$} & \\
\hline 45 & Zinc & G. asiatica & Seeds & $2.04 \mathrm{mg} / 100 \mathrm{~g}$ & & [33] & \\
\hline 46 & Cobalt & G. asiatica & Fruits & $33.0 \mu \mathrm{g} / 100 \mathrm{~g}$ & & [39] & \\
\hline 46 & Cobalt & G. asiatica & Fruits & $0.46 \mathrm{mg} / 100 \mathrm{~g}$ & & {$[38]$} & \\
\hline 47 & Nickel & G. asiatica & Fruits & $87.00 \mu \mathrm{g} / 100 \mathrm{~g}$ & & [39] & \\
\hline 48 & Chromium & G. asiatica & Fruits & $36.00 \mu \mathrm{g} / 100 \mathrm{~g}$ & & [39] & \\
\hline \multicolumn{8}{|c|}{ Vitamins } \\
\hline 49 & Vitamin B1 & G. asiatica & Fruits & $0.02 \mathrm{mg} / 100 \mathrm{~g} \mathrm{FW}$ & & [31] & \\
\hline 50 & Vitamin B2 & G. asiatica & Fruits & $0.26 \mathrm{mg} / 100 \mathrm{~g} \mathrm{FW}$ & & [31] & \\
\hline 51 & Vitamin B3 & G. asiatica & Fruits & $0.825 \mathrm{mg} / 100 \mathrm{~g} \mathrm{FW}$ & & [31] & \\
\hline 52 & Vitamin A & G. asiatica & Fruits & 0.89 I.U & & [38] & \\
\hline 53 & Vitamin C & G. asiatica & Fruits & $4.38 \mathrm{mg} / 100 \mathrm{~g}$ & & [31] & \\
\hline 53 & Vitamin C & G. asiatica & Fruits & $5.21 \mathrm{mg} / 100 \mathrm{~g}$ & & [38] & \\
\hline \multicolumn{8}{|c|}{ Secondary metabolites } \\
\hline Serial number & Secondary Metabolites & Category & Species & Type of Extract & Quantity ( $\mu \mathrm{g} / \mathrm{g}$ ) & Detection Methods & References \\
\hline \multicolumn{8}{|c|}{ Flavonoids } \\
\hline 54 & Pelargonidin 3,5-diglucoside & Anthocyanin & G. asiatica & Methanol & Not evaluated & Not available & [21] \\
\hline 55 & Naringenin-7-O- $\beta$-D-glucoside & Flavanone & G. asiatica & Methanol & Not evaluated & Not available & [21] \\
\hline 56 & Cyanidin-3-O-arabinoside & Anthocyanin & G. asiatica & Acidified methanol & 2.29 & LC-QTOF-MS/MS & [13] \\
\hline 57 & Cyanidin-3-O-sambubioside & Anthocyanin & G. asiatica & Acidified methanol & 27.6 & LC-QTOF-MS/MS & [13] \\
\hline
\end{tabular}


Table 1. Cont.

\begin{tabular}{|c|c|c|c|c|c|c|c|c|}
\hline 58 & $\begin{array}{l}\text { Cyanidin-3-O-(6" } 6^{\prime \prime} \text {-malonyl-3" } \\
\text { glucosylglucoside })\end{array}$ & Anthocyanin & G. asiatica & Fruit & Acidified methanol & 1.01 & LC-QTOF-MS/MS & [13] \\
\hline 59 & Delphinidin-3-O-arabinoside & Anthocyanin & G. asiatica & Fruit & Acidified methanol & 6.51 & LC-QTOF-MS/MS & [13] \\
\hline 60 & Delphinidin-3-O-sambubioside & Anthocyanin & G. asiatica & Fruit & Acidified methanol & 0.80 & LC-QTOF-MS/MS & [13] \\
\hline 61 & Petunidin & Anthocyanin & G. asiatica & Fruit & Acidified methanol & 0.40 & LC-QTOF-MS/MS & [13] \\
\hline 62 & Cyanidin-3-O-6" ${ }^{\prime \prime}$-acetylglucoside & Anthocyanin & G. asiatica & Fruit & Acidified methanol & 695 & $\begin{array}{c}\text { HPLC } \\
\text { (diode array detector) }\end{array}$ & [26] \\
\hline 64 & $\begin{array}{l}\text { Pelargonidin-3-O-6" } \\
\text { acetylglucoside }\end{array}$ & Anthocyanin & G. asiatica & Fruit & Acidified methanol & 140.4 & $\begin{array}{c}\text { HPLC } \\
\text { (diode array detector) }\end{array}$ & [26] \\
\hline 65 & Malvidin-3-O-glucoside & Anthocyanin & G. asiatica & Fruit & Acidified methanol & Traces & $\begin{array}{c}\text { HPLC } \\
\text { (diode array detector) }\end{array}$ & [26] \\
\hline 66 & Delphinidin-3-O-glucoside & Anthocyanin & G. asiatica & Fruit & Acidified methanol & Traces & $\begin{array}{c}\text { HPLC } \\
\text { (diode array detector) }\end{array}$ & [26] \\
\hline 67 & Peonidin-3-O-glucoside & Anthocyanin & G. asiatica & Fruit & Acidified methanol & Traces & $\begin{array}{c}\text { HPLC } \\
\text { (diode array detector) }\end{array}$ & [26] \\
\hline 68 & $\begin{array}{l}\text { Pelargonidin-3-O-malonyl } \\
\text { glucoside }\end{array}$ & Anthocyanin & G. asiatica & Fruit & Acidified methanol & Traces & $\begin{array}{c}\text { HPLC } \\
\text { (diode array detector) }\end{array}$ & [26] \\
\hline 69 & Calycosin & Isoflavonoid & G. asiatica & Fruit & Methanol & Not evaluated & LC-ESI/MS/MS & [24] \\
\hline 70 & Dihydrodaidzein-7-O-glucuronide & Isoflavonoid & G. asiatica & Fruit & Acidified methanol & 0.17 & LC-QTOF-MS/MS & [13] \\
\hline 71 & $\begin{array}{c}6,7,3^{\prime}, 4^{\prime}- \\
\text { Tetrahydroxyisoflavone }\end{array}$ & Isoflavonoid & G. asiatica & Fruit & Acidified methanol & 0.12 & LC-QTOF-MS/MS & [13] \\
\hline 72 & $\begin{array}{c}5,7,8,3^{\prime}, 4^{\prime}- \\
\text { Pentahydroxyisoflavone }\end{array}$ & Isoflavonoid & G. asiatica & Fruit & Acidified methanol & 0.51 & LC-QTOF-MS/MS & [13] \\
\hline 73 & $\begin{array}{c}\text { Apigenin-6- } C \text {-galactoside- } 8-C \text { - } \\
\text { arabinoside }\end{array}$ & Flavone & G. asiatica & Fruit & Acidified methanol & 0.71 & LC-QTOF-MS/MS & [13] \\
\hline 74 & Apigenin-7-O-apiosylglucoside & Flavone & G. asiatica & Fruit & Acidified methanol & 0.33 & LC-QTOF-MS/MS & [13] \\
\hline 75 & Luteolin- $4^{\prime}$-glucoside & Flavone & G. asiatica & Fruit & Acidified methanol & 0.41 & LC-QTOF-MS/MS & [13] \\
\hline
\end{tabular}


Table 1. Cont.

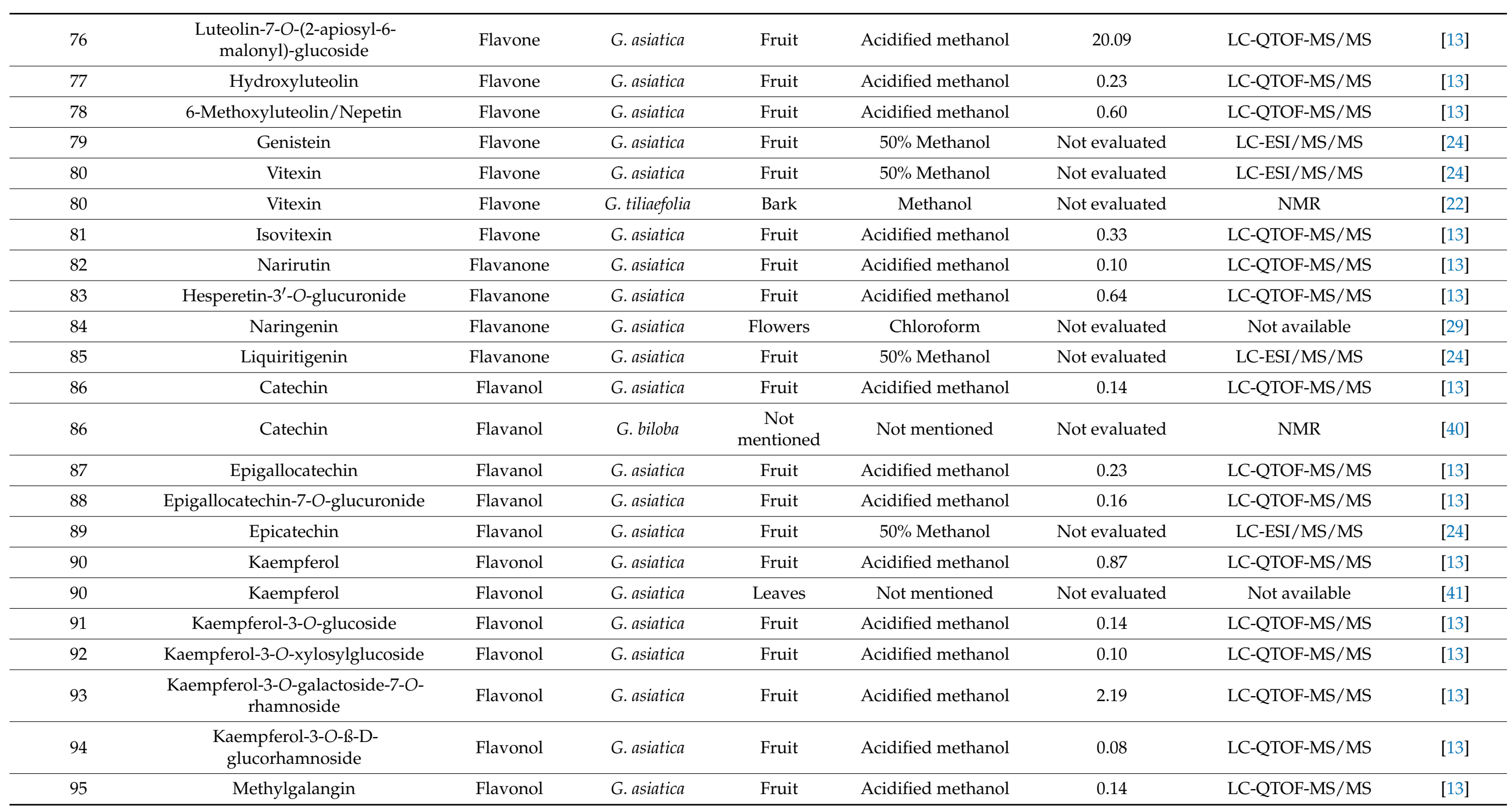


Table 1. Cont.

\begin{tabular}{|c|c|c|c|c|c|c|c|c|}
\hline 96 & Methylgalangin & Flavonol & G. asiatica & Fruit & Acidified methanol & & LC-QTOF-MS/MS & [13] \\
\hline 97 & Myricetin & Flavonol & G. asiatica & Fruit & Acidified methanol & 4.87 & LC-QTOF-MS/MS & [13] \\
\hline 97 & Myricetin & Flavonol & G. asiatica & Fruit & $50 \%$ Methanol & Not evaluated & LC-ESI/MS/MS & [24] \\
\hline 99 & Myricetin-3-O-rhamnoside & Flavonol & G. asiatica & Fruit & Acidified methanol & 0.75 & LC-QTOF-MS/MS & [13] \\
\hline 100 & Myricetin-3-O-galactoside & Flavonol & G. asiatica & Fruit & Acidified methanol & 0.73 & LC-QTOF-MS/MS & [13] \\
\hline 101 & Morin & Flavonol & G. asiatica & Fruit & Acidified methanol & 4.25 & LC-QTOF-MS/MS & [13] \\
\hline 101 & Morin & Flavonol & G. optiva & Leaves & Water & Not evaluated & $\begin{array}{c}\text { HPLC } \\
\text { (diode array detector) }\end{array}$ & [27] \\
\hline 102 & Quercetin & Flavonol & G. asiatica & Fruit & Acidified methanol & 0.44 & LC-QTOF-MS/MS & [13] \\
\hline 102 & Quercetin & Flavonol & G. asiatica & Fruits & Methanol & Not evaluated & Not available & [21] \\
\hline 102 & Quercetin & Flavonol & G. asiatica & Callus & $80 \%$ Methanol & $2.42 \mathrm{ng} / \mu \mathrm{L}$ & TLC & [8] \\
\hline 102 & Quercetin & Flavonol & G. asiatica & Leaves & $80 \%$ Methanol & $4.28 \mathrm{ng} / \mu \mathrm{L}$ & TLC & [8] \\
\hline 102 & Quercetin & Flavonol & G. asiatica & Fruit & $50 \%$ Methanol & Not evaluated & LC-ESI/MS/MS & [24] \\
\hline 104 & Quercetin-7-O-glucoside & Flavonol & G. asiatica & Fruit & Acidified methanol & 0.10 & LC-QTOF-MS/MS & [13] \\
\hline 105 & Quercetin-4'-O-glucoside & Flavonol & G. asiatica & Fruit & Acidified methanol & 0.12 & LC-QTOF-MS/MS & [13] \\
\hline 106 & $\begin{array}{l}\text { Quercetin-3-O-(6"-malonyl- } \\
\text { glucoside) }\end{array}$ & Flavonol & G. asiatica & Fruit & Acidified methanol & 0.31 & LC-QTOF-MS/MS & [13] \\
\hline 107 & Quercetin-3-O-glucosylxylosid & Flavonol & G. asiatica & Fruit & Acidified methanol & 34.43 & LC-QTOF-MS/MS & [13] \\
\hline 108 & $\begin{array}{l}\text { Quercetin-3-O-galactoside7-O- } \\
\text { rhamnoside }\end{array}$ & Flavonol & G. asiatica & Fruit & Acidified methanol & 0.14 & LC-QTOF-MS/MS & [13] \\
\hline 109 & Rhamnetin & Flavonol & G. asiatica & Fruit & Acidified methanol & 2.91 & LC-QTOF-MS/MS & [13] \\
\hline 110 & $\begin{array}{l}\text { Isorhamnetin-3-O-pentaside-7-O- } \\
\text { glucoside }\end{array}$ & Flavonol & G. asiatica & Fruit & Acidified methanol & 1.23 & LC-QTOF-MS/MS & [13] \\
\hline 111 & Quercetin 3-O- $\beta$-D-glucoside & Flavonol & G. asiatica & Fruits & Methanol & Not evaluated & Not available & [21] \\
\hline
\end{tabular}


Table 1. Cont.

Isorhamnetol 5-O-

112 [6 " (3-hydroxy-3-methyl

D-glucoside

\begin{tabular}{|c|c|c|c|c|c|c|c|c|}
\hline 113 & $\begin{array}{c}\text { Kaempferol } \\
\text { 3-O- } \beta \text {-D-glucopyranoside }\end{array}$ & Flavonol & G. asiatica & Fruits & Ethyl acetate & Not evaluated & NMR & [2] \\
\hline 114 & $\begin{array}{c}\text { Kaempferol } \\
\text { 3-O- } \beta \text {-rhamnpyrnoside }\end{array}$ & Flavonol & G. asiatica & Fruits & Ethyl acetate & Not evaluated & NMR & [2] \\
\hline 115 & Quercetin 3-O-glucoside & Flavonol & G. asiatica & Fruits & Water & Not evaluated & NMR & [2] \\
\hline 116 & Quercetin 3-O-rhamnoside & Flavonol & G. asiatica & Fruits & Water & Not evaluated & NMR & [2] \\
\hline 117 & $\begin{array}{c}\text { Quercetin } \\
3-O-\beta-D-2-p \text {-coumaroylglucoside }\end{array}$ & Flavonol & G. asiatica & Fruits & Water & Not evaluated & NMR & [2] \\
\hline 118 & Myricetin 3-O- $\beta$-D-xyloside & Flavonol & G. asiatica & Fruits & Water & Not evaluated & NMR & [2] \\
\hline 119 & Salvianolic acid D & Flavonol & G. asiatica & Fruit & Acidified methanol & 0.40 & LC-QTOF-MS/MS & [13] \\
\hline 120 & 7-Hydroxyflavan & Flavonol & G. asiatica & Fruit & Acidified methanol & 0.10 & LC-QTOF-MS/MS & [13] \\
\hline 121 & 7-O-Methyl cathechin & Flavanol & G. optiva & Root & Methanol & Not evaluated & NMR & [14] \\
\hline 122 & Dihydroquercetin & Dihydroflavonol & G. asiatica & Fruit & Acidified methanol & 1.03 & LC-QTOF-MS/MS & [13] \\
\hline 123 & Dihydroquercetin-3-O-hexoside & Dihydroflavonol & G. asiatica & Fruit & Acidified methanol & 0.14 & LC-QTOF-MS/MS & [13] \\
\hline 124 & Gallic acid & Phenolic acid & G. asiatica & Fruit & $50 \%$ Methanol & Not evaluated & LC-ESI/MS/MS & [24] \\
\hline 124 & Gallic acid & Phenolic acid & G. asiatica & Fruit & Methanol & Not evaluated & LC-ESI/MS/MS & [24] \\
\hline 124 & Gallic acid & Phenolic acid & G. optiva & Leaves & Water & Not evaluated & $\begin{array}{c}\text { HPLC } \\
\text { (diode array detector) }\end{array}$ & {$[27]$} \\
\hline 125 & Caffeic acid & Phenolic acid & G. asiatica & Fruit & Methanol & Not evaluated & LC-ESI/MS/MS & [24] \\
\hline 125 & Caffeic acid & Phenolic acid & G. asiatica & Fruit & Methanol & Not evaluated & LC-ESI/MS/MS & [24] \\
\hline 126 & Quinic acid & Phenolic acid & G. asiatica & Fruit & Methanol & Not evaluated & LC-ESI/MS/MS & [24] \\
\hline 127 & Ellagic acid & Phenolic acid & G. asiatica & Fruit & Methanol & Not evaluated & LC-ESI/MS/MS & [24] \\
\hline 127 & Ellagic acid & Phenolic acid & G. asiatica & Fruit & Methanol & Not evaluated & LC-ESI/MS/MS & [24] \\
\hline 127 & Ellagic acid & Phenolic acid & G. optiva & Leaves & Water & Not evaluated & HPLC & [27] \\
\hline
\end{tabular}


Table 1. Cont.

\begin{tabular}{|c|c|c|c|c|c|c|c|c|}
\hline 128 & Chlorogenic acid & Phenolic acid & G. asiatica & Fruit & Methanol & Not evaluated & LC-ESI/MS/MS & [24] \\
\hline 128 & Chlorogenic acid & Phenolic acid & G. asiatica & Fruit & Methanol & Not evaluated & LC-ESI/MS/MS & [24] \\
\hline 128 & Chlorogenic acid & Phenolic acid & G. optiva & Leaves & Water & Not evaluated & $\begin{array}{c}\text { HPLC } \\
\text { (diode array detector) }\end{array}$ & [27] \\
\hline 129 & Malic acid & Phenolic acid & G. optiva & Leaves & Water & Not evaluated & $\begin{array}{c}\text { HPLC } \\
\text { (diode array detector) }\end{array}$ & [27] \\
\hline 130 & Ascorbic acid & Phenolic acid & G. optiva & Leaves & Water & Not evaluated & $\begin{array}{c}\text { HPLC } \\
\text { (diode array detector) }\end{array}$ & [27] \\
\hline 131 & 3, 4-Dihydroxybenzoic acid & Phenolic acid & G. asiatica & Fruits & Water & Not evaluated & NMR & [2] \\
\hline \multicolumn{9}{|c|}{ Phytosterols } \\
\hline 132 & $\beta$-Sitosterol & Phytosterol & G. asiatica & Flowers & Chloroform & Not evaluated & Not available & [29] \\
\hline 132 & $\beta$-Sitosterol & Phytosterol & G. biloba & Not mentioned & Not mentioned & Not evaluated & NMR & [40] \\
\hline 132 & $\beta$-Sitosterol & Phytosterol & G. optiva & Root & Methanol & Not evaluated & NMR & [14] \\
\hline 133 & Stigmasterol & Phytosterol & G. asiatica & Pomace & Aqueous acetone & Not evaluated & GC/MS & [30] \\
\hline 133 & Stigmasterol & Phytosterol & G. microcos & Roots & Ethanol & Not evaluated & NMR & [37] \\
\hline \multicolumn{9}{|c|}{ Triterpenes } \\
\hline 135 & Betulin & Triterpene & G. asiatica & Stem bark & Petroleum ether & Not evaluated & GC/MS & [28] \\
\hline 136 & Lupeol & Triterpene & G. asiatica & Stem bark & Petroleum ether & Not evaluated & GC/MS & [28] \\
\hline 136 & Lupeol & Triterpene & G. lasiocarpa & Stem bark & Chloroform & Not evaluated & GC/MS & [15] \\
\hline 137 & Lupenone & Triterpene & G. asiatica & Stem bark & Petroleum ether & Not evaluated & GC/MS & [28] \\
\hline 138 & Friedelin & Triterpene & G. asiatica & Stem bark & Petroleum ether & Not evaluated & GC/MS & [28] \\
\hline 138 & Friedelin & Triterpene & G. biloba & Not mentioned & Not mentioned & Not evaluated & NMR & [40] \\
\hline 139 & Epi-friedelan-3-ol & Triterpene & G. biloba & Not mentioned & Not mentioned & Not evaluated & NMR & [40] \\
\hline 140 & $\beta$-Amyrin & Triterpene & G. asiatica & Stem bark & Petroleum ether & Not evaluated & GC/MS & [28] \\
\hline 141 & Betulinic acid & Triterpene & G. optiva & Root & Methanol & Not evaluated & NMR & [14] \\
\hline 142 & Ursolic acid & Triterpene & G. microcos & Root & Ethanol & Not evaluated & NMR & [37] \\
\hline
\end{tabular}


Table 1. Cont.

\begin{tabular}{|c|c|c|c|c|c|c|c|c|}
\hline \multicolumn{9}{|c|}{ Hydroxycinnamic acids } \\
\hline 143 & $p$-Coumaroyl glycolic acid & $\begin{array}{l}\text { Hydroxycinnamic } \\
\text { acid }\end{array}$ & G. asiatica & Fruit & Acidified methanol & 0.58 & LC-QTOF-MS/MS & [24] \\
\hline 144 & 5-Caffeoylquinic acid & $\begin{array}{l}\text { Hydroxycinnamic } \\
\text { acid }\end{array}$ & G. asiatica & Fruit & Acidified methanol & 0.25 & LC-QTOF-MS/MS & [24] \\
\hline \multicolumn{9}{|c|}{ Carboxylic acids } \\
\hline 145 & 1,5-Dimethyl citrate & $\begin{array}{l}\text { Carboxylic } \\
\text { acid }\end{array}$ & G. asiatica & Fruits & Water & Not evaluated & NMR & [2] \\
\hline 146 & Trimethyl citrate & $\begin{array}{l}\text { Carboxylic } \\
\text { acid }\end{array}$ & G. asiatica & Fruits & Water & Not evaluated & NMR & [2] \\
\hline 147 & Heneicosanoic acid & $\begin{array}{l}\text { Carboxylic } \\
\text { acid }\end{array}$ & G. biloba & $\begin{array}{l}\text { Not } \\
\text { mentioned }\end{array}$ & Not mentioned & Not evaluated & NMR & [40] \\
\hline 148 & Glutaric acid & $\begin{array}{l}\text { Carboxylic } \\
\text { acid }\end{array}$ & G. optiva & Root & Methanol & Not evaluated & NMR & [14] \\
\hline 149 & Hexanedioic acid & $\begin{array}{l}\text { Carboxylic } \\
\text { acid }\end{array}$ & G. optiva & Root & Methanol & Not evaluated & NMR & [14] \\
\hline \multicolumn{9}{|c|}{ Sesquiterpenoid } \\
\hline 150 & $\begin{array}{c}\text { D-Erythro-2-hexenoic acid } \\
\qquad \gamma \text {-lactone }\end{array}$ & Sesquiterpenoid & G. tiliaefolia & Bark & Methanol & Not evaluated & NMR & [22] \\
\hline 151 & Gulonic acid $\gamma$-lactone & Sesquiterpenoid & G. tiliaefolia & Bark & Methanol & Not evaluated & NMR & [22] \\
\hline \multicolumn{9}{|c|}{ 7-Hydroxycoumarin } \\
\hline 152 & Umbelliferone & $\begin{array}{c}\text { 7- } \\
\text { Hydroxycoumarins }\end{array}$ & G. asiatica & Fruit & Acidified methanol & 0.10 & LC-QTOF-MS/MS & [13] \\
\hline \multicolumn{9}{|c|}{ Fatty alcohol } \\
\hline 153 & Grewinol & Fatty alcohol & G. asiatica & Flowers & Chloroform & Not evaluated & Not available & [42] \\
\hline \multicolumn{9}{|c|}{ Phenol } \\
\hline 154 & Vidalenolone & Phenol & G. asiatica & Fruit & Methanol & Not evaluated & LC-ESI/MS/MS & [24] \\
\hline \multicolumn{9}{|c|}{ Xanthone } \\
\hline 155 & Mangiferin & Xanthone & G. asiatica & Fruit & Methanol & Not evaluated & LC-ESI/MS/MS & [24] \\
\hline
\end{tabular}


Table 1. Cont.

\begin{tabular}{|c|c|c|c|c|c|c|c|c|}
\hline \multicolumn{9}{|c|}{ Hydroxyquinol } \\
\hline 156 & 1,2,3-Benzene triol & Hydroxyquinols & G. optiva & Root & Methanol & Not evaluated & NMR & {$[14$} \\
\hline \multicolumn{9}{|c|}{ Carotenoid } \\
\hline \multicolumn{9}{|c|}{ Other compounds } \\
\hline 158 & $\begin{array}{c}\text { 5,5,7,7,11,13-Hexamethyl-2-(5- } \\
\text { methylhexyl)icosahydro-1H- } \\
\text { cyclopenta[a]chrysen-9-ol }\end{array}$ & Other & G. optiva & Stem & Methanol & Not evaluated & GC/MS & {$[25$} \\
\hline 159 & 5-Hydroxymethylfurfural & Other & G. asiatica & Fruits & Water & Not evaluated & NMR & [2] \\
\hline 160 & 3,5-Dihydroxy phenyl acrylic acid & Other & G. optiva & Root & Methanol & Not evaluated & NMR & {$[14$} \\
\hline 161 & $\begin{array}{l}\text { (2,5 Dihydroxy phenyl) } \\
3^{\prime}, 6^{\prime}, 8^{\prime} \text {-trihydroxyl- } 4 \mathrm{H} \\
\text { chromen- } 4^{\prime} \text {-one }\end{array}$ & Other & G. optiva & Root & Methanol & Not evaluated & NMR & {$[14$} \\
\hline 162 & $\begin{array}{l}\text { 2,2'-(1,4-phenylene)bis(3-methylbutanoic } \\
\text { acid }\end{array}$ & ic Other & G. optiva & Stem & Methanol & Not evaluated & NMR & {$[25$} \\
\hline 164 & Methanetriol mano formate & Other & G. optiva & Stem & Methanol & Not evaluated & GC/MS & {$[25$} \\
\hline 165 & Dibutyl phthalate & Other & G. microcos & Roots & Ethanol & Not evaluated & NMR & {$[37]$} \\
\hline 166 & Propyl palmitate & Other & G. biloba & Not mentioned & Not mentioned & Not evaluated & NMR & {$[40]$} \\
\hline 167 & $(4 Z, 12 Z)$-Cyclopentadeca-4,12-dienone & Other & G. hirsuta & Leaves & Methanol & Not evaluated & NMR & {$[23]$} \\
\hline
\end{tabular}




\subsection{Chemical Composition}

Five studies reported qualitative and quantitative analyses of the proximate composition of various Grewia species including G. asiatica, G. tenax, G. flavescence, G. villosa, G. tilifolia, and G. nervosa $[31,33-35]$. The total content of carbohydrates, fibers, lipids, proteins, and ash was reported in the fruits, seeds, and leaves. The data illustrate that carbohydrate contents were higher in the fruits, ranging between 21 and 84\% [34], followed by seeds, $39-66 \%$ [33,35], and leaves, $28-40 \%$ [32]. The fat content in seeds was reported as $11.1 \%$ [33] and was almost six times higher than that recoded in fruits $(0.10-1.70 \%)[31,34]$ and three times higher than leaves (2.60-3.86\%) [32]. On an average basis, leaves (12.9-18.9\%) and seeds $(7.50-17.4 \%)$ were reported to be a rich source of protein in contrast to fruits $(1.57-8.7 \%)$. A similar trend was observed for fiber wherein the leaves exhibited more fiber content, $28.3-38.3 \%$, followed by seeds at $14.8-26.1 \%$, and fruits at $5.53-25.5 \%$ on average. Ash content $(6-11 \%)$ in leaves was on average almost three or two times higher when compared to seeds $(3-5.08 \%)$ or fruits $(1.1-5.2 \%)$. Table 1 represents in detail the proximate composition of the different Grewia species.

Fruits and vegetables contain a huge array of secondary metabolites and in fact, these metabolites form the basis for numerous commercial pharmaceutical drugs, as well as herbal remedies derived from medicinal plants [43]. Today, the pharmacological and disease-preventing role of various classes of phytochemicals is firmly established. These chemical constituents predominantly act as antioxidants, anticancer agents, detoxifying agents, and immunity-potentiating and neuropharmacological agents [2,44]. Grewia has been shown to contain a wide variety of phytochemicals and bioactive compounds. Among the seven Grewia species considered for the phytochemistry study, G. asiatica was explored in eleven studies, G. optiva in three articles, and G. lasiocarpa, G. biloba, G. microcos, G. tiliaefolia, and G. hirsuta in each study. The information on phytochemical identification/quantification was reported in 19 articles, and three of them performed the quantification analysis $[8,13,26]$.

Regarding the plant parts analyzed in each study, the fruits of G. asiatica were the most explored, with five articles studying fruits alone $[2,13,21,24,26,30]$. Two articles focused on G. asiatica leaves [8,41], two explored G. asiatica flowers [29,42], one studied Grewia optiva leaves [27], one studied G. asiatica stems [28] and each studied G. microcos [37] and G. lasiocarpa stems [15], G. tiliaefolia bark [22], G. hirsute leaves [23], and G. optiva roots [14] and stems [25] to identify the phytochemical constituents.

We found 113 secondary metabolites reported from G. asiatica, G. optiva, G. tiliaefolia, G. biloba, G. microcos, G. hirsuta, and G. lasiocarpa allocated to 13 categories wherein 102 compounds were reported from G. asiatica, 19 were identified from G. optiva, three were identified from G. tiliaefolia, six were identified from G. biloba, seven were identified from G. microcos, one was identified from G. hirsuta, and one was identified from G. lasiocarpa. The same compounds identified in different studies were considered as a single compound with each presented with a respective reference. Flavonoids represented $41.3 \%$ of the reported bioactive compounds wherein the most dominant subgroup was anthocyanins $(13.04 \%)$ followed by flavones (6.95\%), flavanones (3.47\%), isoflavonoids $(3.47 \%)$, and flavanols $(3.47 \%)$. Phenolic acids represented $6.95 \%$ of the reported compounds followed by triterpenes $(6.95 \%)$, carboxylic acid $(3.47 \%)$, phytosterols $(2.60 \%)$, dihydroflavonols $(1.73 \%)$, hydroxycinnamic acids $(1.73 \%)$, sesquiterpenoids $(1.73 \%)$, fatty acids $(1.73 \%)$, 7-hydroxycoumarin $(0.86 \%)$, fatty alcohol $(0.86 \%)$, phenols $(0.86 \%)$, xanthones $(0.86 \%)$ and hydroxyquinols $(0.86 \%)$.

Of the 113 reported secondary metabolites, information on concentration was available for only $62(54.86 \%)$ of them, grouped in 3 categories including flavonoids (anthocyanins, isoflavonoids, flavone, flavanones, flavanols, flavonols, dihydroflavonols), hydroxycinnamic acid, and 7-hydroxycoumarins. Table 1 presents the compounds according to the parts of the plant. Eight categories of secondary metabolites were studied in fruits, four in stem bark, three in flowers, three were reported in leaves, and one in pomace. Out of 19 stud- 
ies, only 3 performed the quantitative analysis $[8,13,26]$ whereas 16 articles without quantitative information of bioactive metabolites were reported [2,14,15,21-25,27-30,37,40-42].

\subsection{Biological Activity}

\subsubsection{Antioxidant Activity}

Antioxidant-based drug formulations are used for the prevention and adjunct treatment of complex diseases such as Alzheimer's, stroke, cancer, diabetes, and atherosclerosis, whose etiology is partly dependent on persistent oxidative damage by free radicals. Grewia has been identified as a candidate for the development of nutraceutical products by virtue of an array of relevant bioactive compounds. Further investigations at the molecular level, however, are still needed to explore and discuss the mechanisms of action of these active ingredients [2,45].

Eleven studies investigated the antioxidant potential of the Grewia species; eight of them studied G. asiatica [1,24,46-51], one article focused on G. optiva [27], one evaluated G. lasiocarpa [15], and one appraised both G. flava and G. biocolor [52]. The scavenging and reducing potential of various parts of the Grewia species was reported to be dose dependent. 2,2-Diphenyl-1-picrylhydrazyl (DPPH) was the most commonly employed antioxidant assay utilized in nine studies along with other methods, ABTS $\left(2,2^{\prime}\right.$-azinobis (3-ethylbenzothiazoline-6-sulfonic acid)) in three, ferric reducing antioxidant power (FRAP) in three, nitric oxide (NO) in two, and hydrogen peroxide $\left(\mathrm{H}_{2} \mathrm{O}_{2}\right)$ in one study. The principle of the DPPH assay involves measuring the change in DPPH color from violet to pale yellow, resulting from the existence of radical scavenging compounds [53]. Six studies indicated that the Grewia species showed notable antioxidant potential against stable free radicals of which five studies were from G. asiatica [24,46,48-50], and one study was from G. optiva [27]. Among the five studies on G. asiatica, four studied the edible portion and one studied the leaves of G. asiatica. Two studies adopted aqueous methanol extraction, two studies used pure methanol, and one study used benzene for extraction. The one reported study on G. optiva focused on leaves and one focused on stems using methanol or water as extraction solvents. Methanol $[24,49]$ and aqueous methanol extracts $[48,50]$ of the G. asiatica fruits showed the substantial scavenging activity to be between 60 and $85 \%$. Another study reported by Gupta et al. [46] recorded an $\mathrm{IC}_{50}$ of $16.19 \mu \mathrm{g} / \mathrm{mL}$ for the benzene extract of the G. asiatica leaves against free radicals in the DPPH assay, which is almost 4.8 times more than standard ascorbic acid noticed with $\mathrm{IC}_{50} 78.17 \mu \mathrm{g} / \mathrm{mL}$ (Table 2).

Three studies used a FRAP assay to evaluate the reducing potential of the Grewia species, of which two studied G. asiatica fruits and one studied the stem of G. lasiocarpa $[15,24,49]$. The FRAP assay estimates the electron donating capacity of any compound based on the reduction of ferric ion $\left(\mathrm{Fe}^{3+}\right.$, as ferric tripyridyl triazine: $\mathrm{Fe}^{3+}$-TPTZ) into ferrous ion $\left(\mathrm{Fe}^{2+}\right.$, as ferrous tripyridyl triazine: $\mathrm{Fe}^{2+}$-TPTZ) [54]. Fifty per cent of the methanolic extract of the G. asiatica fruit evinced a dose-dependent reducing ability of $43 \mathrm{mg}$ gallic acid equivalent per gram (GAE/g) [24] which is approximately 10 times more than $100 \%$ methanolic extract of the G. asiatica fruit extract (4.14 mg GAE/g) [49]. Three studies used the ABTS assay to measure the antioxidant activity of the Grewia species. Similar to the DPPH assay, the ABTS assay determines the antioxidant activity of hydrolysates that scavenge ABTS radicals. The Grewia species showed a dose-dependent ABTS scavenging.

In Figure 5, the meta-analysis for the antioxidant (Figure 5a), anticancer (Figure 5b), anti-inflammatory (Figure 5c), and antimicrobial (Figure 5d) activities is shown. Ten studies were included in the meta-analysis of the antioxidant activities of various Grewia species, as summarized in Figure 5a. The meta-analysis revealed that the Grewia species showed notable antioxidant activity (MRAW $=59.71,95 \% \mathrm{CI}=36.51-82.90, p=0.0, \mathrm{I}^{2}=100 \%$ ) overall. However, a detailed sub meta-analysis of four and three studies unveiled significant antioxidant properties in the DPPH (MRAW $=64.34,95 \% \mathrm{CI}=12.28-116.40, p=0.0$, $\mathrm{I}^{2}=100 \%$ ) and ABTS assay (MRAW $=79.36,95 \% \mathrm{CI}=18.43-140.28, p<0.01, \mathrm{I}^{2}=100 \%$ ), respectively. In contrast, the $\mathrm{NO}, \mathrm{FRAP}$, and $\mathrm{H}_{2} \mathrm{O}_{2}$ assays were only in one study; therefore, a heterogenic analysis was not possible. 
Table 2. In vitro and in vivo biological activities of the Grewia species.

\begin{tabular}{|c|c|c|c|c|c|c|c|c|c|c|c|}
\hline \multicolumn{12}{|c|}{ Antioxidant Effects of Grewia species } \\
\hline Species & Plant Part & Origin & $\begin{array}{l}\text { Extraction } \\
\text { Solvent }\end{array}$ & Activity & Assay & $\begin{array}{c}\text { Activity of } \\
\text { Extract }\end{array}$ & Std Dev & $\begin{array}{l}\text { Positive } \\
\text { Control }\end{array}$ & Activity & Std Dev & References \\
\hline G. asiatica & Leaf & India & Acetone & Antioxidant & $\mathrm{DPPH}$ & $\begin{array}{c}127.5 \mathrm{IC}_{50} \\
\mu \mathrm{g} / \mathrm{mL}\end{array}$ & 0.8 & NG & NG & NG & [1] \\
\hline G. asiatica & Fruit & Pakistan & $\begin{array}{c}50 \% \text { aqueous } \\
\text { Methanol }\end{array}$ & Antioxidant & $\mathrm{DPPH}$ & $\begin{array}{l}41 \mathrm{IC}_{50} \\
\mu \mathrm{g} / \mathrm{mL}\end{array}$ & 0.1 & $\begin{array}{c}\text { Ascorbic } \\
\text { acid }\end{array}$ & $75.1 \mathrm{IC}_{50} \mu \mathrm{g} / \mathrm{mL}$ & 0.01 & {$[24]$} \\
\hline G. asiatica & Fruit & Pakistan & Methanol & Antioxidant & $\mathrm{DPPH}$ & $\begin{array}{l}77 \mathrm{IC}_{50} \\
\mu \mathrm{g} / \mathrm{mL}\end{array}$ & 1.1 & $\begin{array}{c}\text { Ascorbic } \\
\text { acid }\end{array}$ & $75.1 \%$ inhibition & 0.01 & {$[24]$} \\
\hline G. asiatica & Leaf & India & Benzene & Antioxidant & $\mathrm{DPPH}$ & $\begin{array}{c}16.19 \mathrm{IC}_{50} \\
\mu \mathrm{g} / \mathrm{mL}\end{array}$ & 2.1 & $\begin{array}{c}\text { Ascorbic } \\
\text { acid }\end{array}$ & $78.1 \mathrm{IC}_{50} \mu \mathrm{g} / \mathrm{mL}$ & 4.05 & [46] \\
\hline G. optiva & Leaf & Pakistan & Water & Antioxidant & $\mathrm{DPPH}$ & $\begin{array}{l}60 \mathrm{IC}_{50} \\
\mu \mathrm{g} / \mathrm{mL}\end{array}$ & 0.6 & $\begin{array}{c}\text { Ascorbic } \\
\text { acid }\end{array}$ & $28 \mathrm{IC}_{50} \mu \mathrm{g} / \mathrm{mL}$ & 0.40 & [27] \\
\hline G. lasiocarpa & Stem & South Africa & Chloroform & Antioxidant & $\mathrm{DPPH}$ & $\begin{array}{c}>1000 \mathrm{IC}_{50} \\
\mu \mathrm{g} / \mathrm{mL}\end{array}$ & 0.2 & NG & NG & NG & [15] \\
\hline G. asiatica & Fruit & Pakistan & $\begin{array}{c}80 \% \text { aqueous } \\
\text { Methanol }\end{array}$ & Antioxidant & $\mathrm{DPPH}$ & $\begin{array}{c}85 \% \\
\text { inhibition }\end{array}$ & 1.5 & BHA & $89 \%$ inhibition & NG & [48] \\
\hline G. asiatica & Fruit & India & Methanol & Antioxidant & $\mathrm{DPPH}$ & $\begin{array}{c}84.8 \% \\
\text { inhibition }\end{array}$ & 0.9 & NG & NG & NG & [49] \\
\hline G. asiatica & Fruit & Pakistan & Methanol & Antioxidant & $\mathrm{DPPH}$ & $\begin{array}{c}>60 \% \\
\text { inhibition }\end{array}$ & 0.7 & NG & NG & NG & {$[50]$} \\
\hline G. flava & Peel & Botswana & Ethanol & Antioxidant & $\mathrm{DPPH}$ & $\begin{array}{c}375 \mu \mathrm{mol} \\
\mathrm{GAE} / \mathrm{g}\end{array}$ & 1.1 & NG & NG & NG & [52] \\
\hline G. biocolor & Peel & Botswana & Ethanol & Antioxidant & $\mathrm{DPPH}$ & $\begin{array}{c}165 \mu \mathrm{mol} \\
\mathrm{GAE} / \mathrm{g}\end{array}$ & 0.2 & NG & NG & NG & {$[52]$} \\
\hline G. asiatica & Leaf & India & Water & Antioxidant & NO & $\begin{array}{c}1098 \mathrm{IC}_{50} \\
\mu \mathrm{g} / \mathrm{mL}\end{array}$ & 0.9 & NG & NG & NG & {$[51]$} \\
\hline G. asiatica & Leaf & India & Benzene & Antioxidant & NO & $\begin{array}{c}27.0 \mathrm{IC}_{50} \\
\mu \mathrm{g} / \mathrm{mL}\end{array}$ & 1.6 & $\begin{array}{c}\text { Ascorbic } \\
\text { acid }\end{array}$ & $20.5 \mathrm{IC}_{50} \mu \mathrm{g} / \mathrm{mL}$ & 1.7 & {$[46]$} \\
\hline G. asiatica & Seed & Pakistan & Ethyl acetate & Antioxidant & ABTS & $\begin{array}{c}55.8 \mathrm{TEAC} \\
\mu \mathrm{mol} / \mathrm{g}\end{array}$ & 0.3 & NG & NG & NG & [47] \\
\hline
\end{tabular}


Table 2. Cont.

\begin{tabular}{|c|c|c|c|c|c|c|c|c|c|c|c|}
\hline G. asiatica & Peel & Pakistan & $\begin{array}{l}70 \% \text { aqueous } \\
\text { acetone }\end{array}$ & Antioxidant & ABTS & $\begin{array}{c}\text { 107.2 TEAC } \\
\mu \mathrm{mol} / \mathrm{g}\end{array}$ & 2.4 & NG & NG & NG & {$[47]$} \\
\hline G. asiatica & Pulp & Pakistan & $\begin{array}{c}70 \% \text { aqueous } \\
\text { acetone }\end{array}$ & Antioxidant & ABTS & $\begin{array}{l}60.9 \mathrm{TEAC} \\
\mu \mathrm{mol} / \mathrm{g}\end{array}$ & 1.8 & NG & NG & NG & {$[47]$} \\
\hline G. asiatica & Fruit & Pakistan & Methanol & Antioxidant & ABTS & $\begin{array}{c}\% \text { inhibition } \\
>60 \%\end{array}$ & 0.7 & NG & NG & NG & {$[50]$} \\
\hline G. optiva & Leaves & Pakistan & Water & Antioxidant & ABTS & $\begin{array}{l}70 \mathrm{IC}_{50} \\
\mu \mathrm{g} / \mathrm{ml}\end{array}$ & 0.8 & $\begin{array}{l}\text { Ascorbic } \\
\text { acid }\end{array}$ & $30 \mathrm{IC}_{50} \mu \mathrm{g} / \mathrm{mL}$ & 0.30 & [27] \\
\hline G. asiatica & Fruit & India & Methanol & Antioxidant & FRAP & $\begin{array}{l}4.14 \mathrm{mg} \\
\mathrm{GAE} / \mathrm{g}\end{array}$ & 1.1 & NG & NG & NG & [49] \\
\hline G. asiatica & Fruit & Pakistan & $\begin{array}{c}50 \% \\
\text { Aqueous } \\
\text { methanol }\end{array}$ & Antioxidant & FRAP & $\begin{array}{l}43 \mathrm{mg} \\
\mathrm{GAE} / \mathrm{g}\end{array}$ & 0.6 & $\begin{array}{l}\text { Ascorbic } \\
\text { acid }\end{array}$ & $15.0 \mathrm{mg} \mathrm{GAE} / \mathrm{g}$ & 0.01 & {$[24]$} \\
\hline G. asiatica & Fruit & Pakistan & Methanol & Antioxidant & FRAP & $\begin{array}{l}27 \mathrm{mg} \\
\mathrm{GAE} / \mathrm{g}\end{array}$ & 0.7 & $\begin{array}{l}\text { Ascorbic } \\
\text { acid }\end{array}$ & $15.0 \mathrm{mg} \mathrm{GAE} / \mathrm{g}$ & 0.01 & [24] \\
\hline G. lasiocarpa & Stem & South Africa & Chloroform & Antioxidant & FRAP & $\begin{array}{c}>1000 \mathrm{IC}_{50} \\
\mu \mathrm{g} / \mathrm{mL}\end{array}$ & 0.9 & NG & NG & NG & [15] \\
\hline G. asiatica & Fruit & Pakistan & $\begin{array}{c}50 \% \\
\text { Aqueous } \\
\text { methanol }\end{array}$ & Antioxidant & $\mathrm{H}_{2} \mathrm{O}_{2}$ & $\begin{array}{c}73 \% \\
\text { inhibition }\end{array}$ & 0.5 & $\begin{array}{l}\text { Ascorbic } \\
\text { acid }\end{array}$ & $79.1 \%$ inhibition & 0.02 & {$[24]$} \\
\hline G. asiatica & Fruit & Pakistan & Methanol & Antioxidant & $\mathrm{H}_{2} \mathrm{O}_{2}$ & $\begin{array}{c}43 \% \\
\text { inhibition }\end{array}$ & 0.4 & $\begin{array}{l}\text { Ascorbic } \\
\text { acid }\end{array}$ & $79.1 \%$ inhibition & 0.02 & {$[24]$} \\
\hline \multicolumn{12}{|c|}{ Anticancer effects of Grewia species } \\
\hline Species & Plant Part & Origin & $\begin{array}{c}\text { Extracting } \\
\text { Solvent }\end{array}$ & Activity & Assays & $\begin{array}{c}\text { Cancer Cell } \\
\text { Line }\end{array}$ & $\begin{array}{l}\text { Activity of Extract } \\
\left(\mathrm{IC}_{50}\right)\end{array}$ & $\begin{array}{c}\text { Reference } \\
\text { Drug }\end{array}$ & $\begin{array}{l}\text { Activity } \\
\left(\mathrm{IC}_{50}\right)\end{array}$ & Std Dev & References \\
\hline G. asiatica & Fruit & India & Water & Anticancer & MTT & HEp-2 & $50.31 \mu \mathrm{g} / \mathrm{mL}$ & Methotrexate & $0.98 \mu \mathrm{g} / \mathrm{mL}$ & NG & [55] \\
\hline G. asiatica & Leaves & India & Aqueous & Anticancer & MTT & HEp-2 & $61.23 \mu \mathrm{g} / \mathrm{mL}$ & Methotrexate & $0.98 \mu \mathrm{g} / \mathrm{mL}$ & NG & [55] \\
\hline G. asiatica & $\begin{array}{l}\text { Fruit } \\
\text { residue }\end{array}$ & India & Methanol & Anticancer & MTT & HEp-2 & $>250 \mu \mathrm{g} / \mathrm{mL}$ & Not given & NG & NG & {$[30]$} \\
\hline G. asiatica & Fruit & Pakistan & $\begin{array}{l}\text { Aqueous } \\
\text { methanol }\end{array}$ & Anticancer & MTT & HEp-2 & $80.41 \mu \mathrm{g} / \mathrm{mL}$ & Methotrexate & $0.82 \mu \mathrm{g} / \mathrm{mL}$ & NG & [24] \\
\hline
\end{tabular}


Table 2. Cont.

\begin{tabular}{|c|c|c|c|c|c|c|c|c|c|c|c|}
\hline G. asiatica & Fruit & Pakistan & $\begin{array}{l}\text { Aqueous } \\
\text { methanol }\end{array}$ & Anticancer & MTT & HEp-2 & $80.41 \mu \mathrm{g} / \mathrm{mL}$ & Methotrexate & $0.82 \mu \mathrm{g} / \mathrm{mL}$ & NG & {$[24]$} \\
\hline G. asiatica & Fruit & India & Aqueous & Anticancer & MTT & NCI-H522 & $59.03 \mu \mathrm{g} / \mathrm{mL}$ & Methotrexate & $0.96 \mu \mathrm{g} / \mathrm{mL}$ & NG & {$[55$} \\
\hline G. asiatica & Leaves & India & Methanol & Anticancer & MTT & NCI-H522 & $\begin{array}{c}\text { Notable } \\
\text { cytotoxicity }\end{array}$ & NG & NG & NG & {$[56]$} \\
\hline G. asiatica & Fruit & Pakistan & $\begin{array}{l}\text { Aqueous } \\
\text { methanol }\end{array}$ & Anticancer & MTT & NCI-H522 & $73.01 \mu \mathrm{g} / \mathrm{mL}$ & Methotrexate & $0.91 \mu \mathrm{g} / \mathrm{mL}$ & 0.21 & {$[24]$} \\
\hline G. asiatica & Fruit & Pakistan & $\begin{array}{l}\text { Aqueous } \\
\text { methanol }\end{array}$ & Anticancer & MTT & NCI-H522 & $73.01 \mu \mathrm{g} / \mathrm{mL}$ & Methotrexate & $0.91 \mu \mathrm{g} / \mathrm{mL}$ & 0.21 & {$[24]$} \\
\hline G. asiatica & Fruit & India & Aqueous & Anticancer & MTT & MCF-7 & $58.65 \mu \mathrm{g} / \mathrm{mL}$ & Methotrexate & $0.98 \mu \mathrm{g} / \mathrm{mL}$ & 0.4 & {$[55$} \\
\hline G. asiatica & Leaves & India & Aqueous & Anticancer & MTT & MCF-7 & $50.37 \mu \mathrm{g} / \mathrm{mL}$ & Methotrexate & $0.98 \mu \mathrm{g} / \mathrm{mL}$ & 0.4 & {$[55]$} \\
\hline G. asiatica & Leaves & India & Methanol & Anticancer & MTT & MCF-7 & $\begin{array}{c}\text { Notable } \\
\text { cytotoxicity }\end{array}$ & NG & NG & NG & {$[56]$} \\
\hline G. asiatica & Leaves & India & Methanol & Anticancer & MTT & MCF-7 & $199.5 \mu \mathrm{g} / \mathrm{mL}$ & NG & NG & NG & {$[57]$} \\
\hline G. asiatica & $\begin{array}{l}\text { Fruit } \\
\text { residue }\end{array}$ & India & Methanol & Anticancer & MTT & MCF-7 & $68.91 \mu \mathrm{g} / \mathrm{mL}$ & NG & NG & NG & {$[30]$} \\
\hline G. asiatica & Fruit & Pakistan & $\begin{array}{l}\text { Aqueous } \\
\text { methanol }\end{array}$ & Anticancer & MTT & MCF-7 & $34.87 \mu \mathrm{g} / \mathrm{mL}$ & Methotrexate & $0.82 \mu \mathrm{g} / \mathrm{mL}$ & 0.1 & {$[24]$} \\
\hline G. asiatica & Fruit & Pakistan & $\begin{array}{l}\text { Aqueous } \\
\text { methanol }\end{array}$ & Anticancer & MTT & MCF-7 & $34.87 \mu \mathrm{g} / \mathrm{mL}$ & Methotrexate & $0.82 \mu \mathrm{g} / \mathrm{mL}$ & 0.1 & {$[24]$} \\
\hline G. lasiocarpa & Stem bark & South Africa & Chloroform & Anticancer & MTT & MCF-7 & $>1000 \mu \mathrm{g} / \mathrm{mL}$ & NG & NG & NG & {$[15$} \\
\hline G. asiatica & Leaves & India & Methanol & Anticancer & MTT & Hela & $177.8 \mu \mathrm{g} / \mathrm{mL}$ & NG & NG & NG & {$[57$} \\
\hline G. asiatica & $\begin{array}{l}\text { Fruit } \\
\text { residue }\end{array}$ & India & Methanol & Anticancer & MTT & Hela & $>100 \mu \mathrm{g} / \mathrm{mL}$ & NG & NG & NG & {$[30]$} \\
\hline G. lasiocarpa & Stem bark & South Africa & Chloroform & Anticancer & MTT & Hela & $>1000 \mu \mathrm{g} / \mathrm{mL}$ & NG & NG & NG & {$[15$} \\
\hline G. asiatica & Fruits & Pakistan & Methanol & Anticancer & MTT & Hela & $406.5 \mu \mathrm{g} / \mathrm{mL}$ & Methotrexate & 0.89 & 0.31 & {$[24]$} \\
\hline G. asiatica & Fruits & Pakistan & $\begin{array}{l}\text { Aqueous } \\
\text { methanol }\end{array}$ & Anticancer & MTT & Hela & $282.4 \mu \mathrm{g} / \mathrm{mL}$ & Methotrexate & 0.89 & 0.31 & {$[24]$} \\
\hline
\end{tabular}


Table 2. Cont.

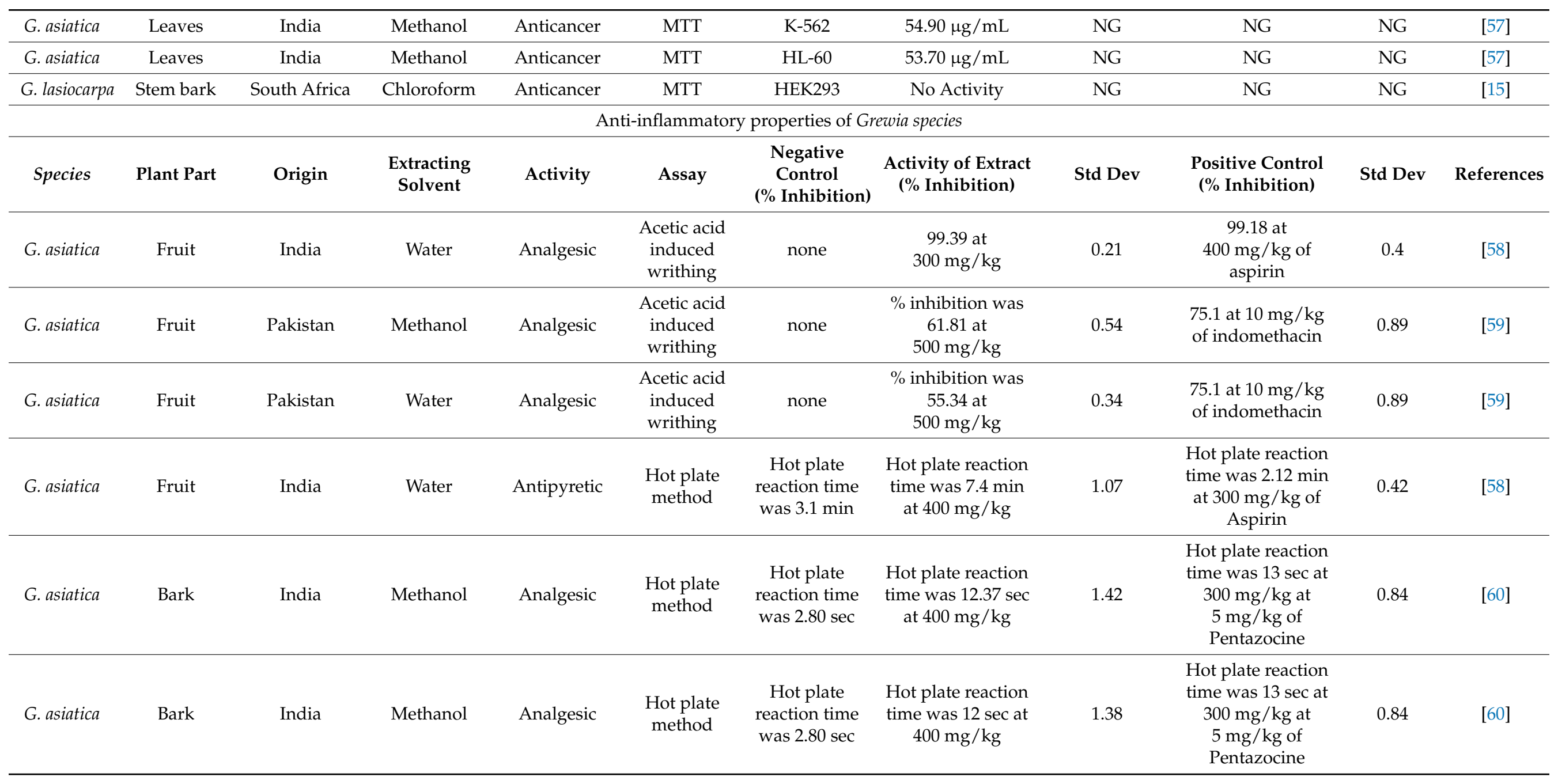


Table 2. Cont.

\begin{tabular}{|c|c|c|c|c|c|c|c|c|c|c|c|}
\hline G. asiatica & Fruit & Pakistan & Methanol & Antipyretic & $\begin{array}{l}\text { Breweris } \\
\text { yeast } \\
\text { induced } \\
\text { pyrexia }\end{array}$ & $\begin{array}{c}\text { Average } \\
\text { temperature } \\
\text { was } 102\end{array}$ & $\begin{array}{c}\text { Average } \\
\text { temperature was } \\
100.81 \text { at } \\
500 \mathrm{mg} / \mathrm{kg}\end{array}$ & 0.19 & $\begin{array}{c}\text { Average } \\
\text { temperature was } \\
98.6 \text { at } 150 \mathrm{mg} / \mathrm{kg} \\
\text { of paracetamol }\end{array}$ & 0.04 & [59] \\
\hline G. asiatica & Bark & India & Methanol & $\begin{array}{c}\text { Anti- } \\
\text { inflammatory }\end{array}$ & $\begin{array}{l}\text { Carrageenan- } \\
\text { induced } \\
\text { paw } \\
\text { oedema }\end{array}$ & $\begin{array}{l}\% \text { inhibition } \\
\text { was } 0\end{array}$ & $\begin{array}{c}\% \text { inhibition was } \\
59.14 \text { at } \\
400 \mathrm{mg} / \mathrm{kg}\end{array}$ & 0.51 & $\begin{array}{l}\% \text { inhibition was } \\
64.2 \text { at } 10 \mathrm{mg} / \mathrm{kg} \\
\text { of indomethacin }\end{array}$ & 0.38 & [60] \\
\hline G. asiatica & Bark & India & Water & $\begin{array}{c}\text { Anti- } \\
\text { inflammatory }\end{array}$ & $\begin{array}{l}\text { Carrageenan- } \\
\text { induced } \\
\text { paw } \\
\text { oedema }\end{array}$ & $\begin{array}{l}\% \text { inhibition } \\
\text { was } 0\end{array}$ & $\begin{array}{c}\% \text { inhibition was } \\
53.04 \text { at } \\
400 \mathrm{mg} / \mathrm{kg}\end{array}$ & 0.39 & $\begin{array}{l}\% \text { inhibition was } \\
64.2 \text { at } 10 \mathrm{mg} / \mathrm{kg} \\
\text { of indomethacin }\end{array}$ & 0.38 & [60] \\
\hline G. asiatica & Fruit & India & Methanol & $\begin{array}{c}\text { Anti- } \\
\text { inflammatory }\end{array}$ & $\begin{array}{l}\text { Carrageenan- } \\
\text { induced } \\
\text { paw } \\
\text { oedema }\end{array}$ & & & & & & [61] \\
\hline G. asiatica & Fruit & Pakistan & Methanol & $\begin{array}{c}\text { Anti- } \\
\text { inflammatory }\end{array}$ & $\begin{array}{l}\text { Carrageenan- } \\
\text { induced } \\
\text { paw } \\
\text { oedema }\end{array}$ & $\begin{array}{l}\% \text { inhibition } \\
\text { was } 0\end{array}$ & $\begin{array}{c}\% \text { inhibition was } \\
36.12 \text { at } \\
500 \mathrm{mg} / \mathrm{kg}\end{array}$ & 0.43 & $\begin{array}{l}\% \text { inhibition was } \\
36.4 \text { at } 10 \mathrm{mg} / \mathrm{kg} \\
\text { of indomethacin }\end{array}$ & 0.03 & [59] \\
\hline G. asiatica & Fruit & Pakistan & Water & $\begin{array}{c}\text { Anti- } \\
\text { inflammatory }\end{array}$ & $\begin{array}{l}\text { Carrageenan- } \\
\text { induced } \\
\text { paw } \\
\text { oedema }\end{array}$ & $\begin{array}{l}\% \text { inhibition } \\
\text { was } 0\end{array}$ & $\begin{array}{c}\% \text { inhibition was } \\
32.44 \text { at } \\
500 \mathrm{mg} / \mathrm{kg}\end{array}$ & 0.21 & $\begin{array}{l}\% \text { inhibition was } \\
36.4 \text { at } 10 \mathrm{mg} / \mathrm{kg} \\
\text { of indomethacin }\end{array}$ & 0.03 & [59] \\
\hline G. asiatica & Leaves & India & $n$-Hexane & $\begin{array}{c}\text { Anti- } \\
\text { inflammatory }\end{array}$ & $\begin{array}{l}\text { Membrane } \\
\text { protection }\end{array}$ & $\begin{array}{l}\% \text { inhibition } \\
\text { was } 0\end{array}$ & $\begin{array}{c}\% \text { inhibition was } \\
80.91 \text { at } \\
600 \mu \mathrm{g} / \mathrm{mL}\end{array}$ & NG & $\begin{array}{c}\% \text { inhibition was } \\
21.1 \mathrm{at} 600 \mu \mathrm{g} / \mathrm{mL} \\
\text { at } 600 \mu \mathrm{g} / \mathrm{mL} \text { of } \\
\text { diclofenac } \\
\text { potassium }\end{array}$ & NG & [62] \\
\hline
\end{tabular}


Table 2. Cont.

\begin{tabular}{|c|c|c|c|c|c|c|c|c|c|c|c|}
\hline G. asiatica & Leaves & India & Methanol & $\begin{array}{c}\text { Anti- } \\
\text { inflammatory }\end{array}$ & $\begin{array}{l}\text { Membrane } \\
\text { protection }\end{array}$ & $\begin{array}{l}\% \text { inhibition } \\
\text { was } 0\end{array}$ & $\begin{array}{l}\% \text { inhibition was } \\
2.5 \text { at } 600 \mu \mathrm{g} / \mathrm{mL}\end{array}$ & NG & $\begin{array}{c}\% \text { inhibition was } \\
21.1 \mathrm{at} 600 \mu \mathrm{g} / \mathrm{mL} \\
\text { at } 600 \mu \mathrm{g} / \mathrm{mL} \text { of } \\
\text { diclofenac } \\
\text { potassium }\end{array}$ & NG & [62] \\
\hline G. optiva & Leaves & India & $n$-Hexane & $\begin{array}{c}\text { Anti- } \\
\text { inflammatory }\end{array}$ & $\begin{array}{l}\text { Membrane } \\
\text { protection }\end{array}$ & $\begin{array}{l}\% \text { inhibition } \\
\text { was } 0\end{array}$ & $\begin{array}{l}\% \text { inhibition was } 0 \\
\text { at } 600 \mu \mathrm{g} / \mathrm{mL}\end{array}$ & NG & $\begin{array}{c}\% \text { inhibition was } \\
21.1 \mathrm{at} 600 \mu \mathrm{g} / \mathrm{mL} \\
\text { at } 600 \mu \mathrm{g} / \mathrm{mL} \text { of } \\
\text { diclofenac } \\
\text { potassium }\end{array}$ & NG & {$[62]$} \\
\hline G. optiva & Leaves & India & Methanol & $\begin{array}{c}\text { Anti- } \\
\text { inflammatory }\end{array}$ & $\begin{array}{l}\text { Membrane } \\
\text { protection }\end{array}$ & $\begin{array}{l}\% \text { inhibition } \\
\text { was } 0\end{array}$ & $\begin{array}{l}\% \text { inhibition was } \\
3.00 \text { at } 600 \mu \mathrm{g} / \mathrm{mL}\end{array}$ & NG & $\begin{array}{c}\% \text { inhibition was } \\
21.1 \mathrm{at} 600 \mu \mathrm{g} / \mathrm{mL} \\
\text { at } 600 \mu \mathrm{g} / \mathrm{mL} \text { of } \\
\text { diclofenac } \\
\text { potassium }\end{array}$ & NG & [62] \\
\hline \multicolumn{12}{|c|}{ Antimicrobial activities of Grewia species } \\
\hline Species & Plant Part & origin & $\begin{array}{l}\text { Extracting } \\
\text { Solvent }\end{array}$ & Activity & $\begin{array}{c}\text { Bacterial/ } \\
\text { Fungal } \\
\text { Strain }\end{array}$ & $\begin{array}{l}\text { Activity of } \\
\text { Extract }\end{array}$ & Std Dev & $\begin{array}{l}\text { Positive } \\
\text { Control }\end{array}$ & Activity & Std Dev & References \\
\hline G. asiatica & Leaves & Pakistan & Ethanol & Antibacterial & S. aureus & $\begin{array}{c}\mathrm{MIC} \text { was } \\
>1 \mathrm{mg} / \mathrm{mL}\end{array}$ & NG & Amoxicillin & $\begin{array}{c}\text { MIC was } \\
20 \mathrm{mg} / \mathrm{mL}\end{array}$ & 0.06 & [63] \\
\hline G. asiatica & Fruit & Pakistan & Methanol & Antibacterial & S. aureus & $\begin{array}{c}\text { MIC was } \\
15.625 \\
\mu \mathrm{g} / \mathrm{mL}\end{array}$ & 0.11 & NG & NG & NG & {$[64]$} \\
\hline G. asiatica & $\begin{array}{l}\text { Bark } \\
\text { Fruit }\end{array}$ & Pakistan & Ethanol & Antibacterial & S. aureus & $\begin{array}{c}\text { Zone of } \\
\text { inhibition } \\
6.33 \mathrm{~mm}\end{array}$ & 0.84 & Moxifloxacin & $\begin{array}{l}\text { Zone of inhibition } \\
\quad 30 \mathrm{~mm}\end{array}$ & NG & [65] \\
\hline G. asiatica & Leaves & Pakistan & Methanol & Antibacterial & S. aureus & $\begin{array}{c}\text { Zone of } \\
\text { inhibition } \\
10.4 \mathrm{~mm}\end{array}$ & 1.1 & Cefixime & $\begin{array}{l}\text { Zone of inhibition } \\
20 \mathrm{~mm}\end{array}$ & 2.5 & [66] \\
\hline G. asiatica & Leaves & Pakistan & Water & Antibacterial & S. aureus & $\begin{array}{c}\text { Zone of } \\
\text { inhibition } \\
13.5 \mathrm{~mm}\end{array}$ & 1.6 & Cefixime & $\begin{array}{l}\text { Zone of inhibition } \\
\qquad 20 \mathrm{~mm}\end{array}$ & 2.5 & {$[66]$} \\
\hline
\end{tabular}


Table 2. Cont.

\begin{tabular}{|c|c|c|c|c|c|c|c|c|c|c|c|}
\hline G. optiva & Leaves & Pakistan & Water & Antibacterial & S. aureus & $\begin{array}{c}\text { Zone of } \\
\text { inhibition } \\
9 \mathrm{~mm}\end{array}$ & 0.99 & Cephradine & $\begin{array}{l}\text { Zone of inhibition } \\
24 \mathrm{~mm}\end{array}$ & 1.20 & [27] \\
\hline G. lasiocarpa & Stem & South Africa & Chloroform & Antibacterial & S. aureus & $\begin{array}{c}\text { No activity } \\
\text { observed }\end{array}$ & NG & Streptomycin & $\begin{array}{c}\text { Zone of inhibition } \\
12.3 \mathrm{~mm}\end{array}$ & 2.31 & [15] \\
\hline G. hirsuta & Leaves & India & $\begin{array}{c}70 \% \text { aqueous } \\
\text { Methanol }\end{array}$ & Antibacterial & S. aureus & $\begin{array}{c}\text { Zone of } \\
\text { inhibition } \\
19 \mathrm{~mm}\end{array}$ & 0.47 & Ciprofloxacin & $\begin{array}{l}\text { Zone of inhibition } \\
22 \mathrm{~mm}\end{array}$ & 2.16 & [67] \\
\hline G. asiatica & Leaves & Pakistan & Methanol & Antibacterial & S. typhi & $\begin{array}{c}\text { Zone of } \\
\text { inhibition } \\
15.2 \mathrm{~mm}\end{array}$ & 1.21 & Cefixime & $\begin{array}{c}\text { Zone of inhibition } \\
21.5 \mathrm{~mm}\end{array}$ & 2.58 & [66] \\
\hline G. asiatica & Leaves & Pakistan & Water & Antibacterial & S. typhi & $\begin{array}{c}\text { No activity } \\
\text { observed }\end{array}$ & NG & Cefixime & $\begin{array}{l}\text { Zone of inhibition } \\
21.5 \mathrm{~mm}\end{array}$ & 2.58 & [66] \\
\hline G. optiva & Leaves & Pakistan & Water & Antibacterial & S. typhi & $\begin{array}{c}\text { Zone of } \\
\text { inhibition } \\
10 \mathrm{~mm}\end{array}$ & 1.32 & Cephradine & $\begin{array}{l}\text { Zone of inhibition } \\
21 \mathrm{~mm}\end{array}$ & 0.61 & [27] \\
\hline G. lasiocarpa & Stem & South Africa & Chloroform & Antibacterial & S. typhi & $\begin{array}{c}\text { No activity } \\
\text { observed }\end{array}$ & NG & Gentamicin & $\begin{array}{c}\text { Zone of inhibition } \\
19.33 \mathrm{~mm}\end{array}$ & 1.92 & [15] \\
\hline G. asiatica & Leaves & Pakistan & Methanol & Antibacterial & E. coli & $\begin{array}{c}\text { No activity } \\
\text { observed }\end{array}$ & NG & Cefixime & $\begin{array}{l}\text { No activity } \\
\text { observed }\end{array}$ & NG & [66] \\
\hline G. asiatica & Leaves & Pakistan & Water & Antibacterial & E. coli & $\begin{array}{c}\text { No activity } \\
\text { observed }\end{array}$ & NG & Cefixime & $\begin{array}{l}\text { No activity } \\
\text { observed }\end{array}$ & NG & [66] \\
\hline G. optiva & Leaves & Pakistan & Water & Antibacterial & E. coli & $\begin{array}{c}\text { Zone of } \\
\text { inhibition } \\
9 \mathrm{~mm}\end{array}$ & 1.20 & Cephradine & $\begin{array}{l}\text { Zone of inhibition } \\
23 \mathrm{~mm}\end{array}$ & 0.20 & [27] \\
\hline G. lasiocarpa & Stem & South Africa & Chloroform & Antibacterial & E. coli & $\begin{array}{c}\text { No activity } \\
\text { observed }\end{array}$ & NG & Gentamicin & $\begin{array}{c}\text { Zone of inhibition } \\
18.3 \mathrm{~mm}\end{array}$ & 1.68 & [15] \\
\hline G. hirsuta & Leaves & India & $\begin{array}{c}70 \% \\
\text { Aqueous } \\
\text { methanol }\end{array}$ & Antibacterial & E. coli & $\begin{array}{c}\text { Zone of } \\
\text { inhibition } \\
16 \mathrm{~mm}\end{array}$ & 2.05 & Ciprofloxacin & $\begin{array}{l}\text { Zone of inhibition } \\
18 \mathrm{~mm}\end{array}$ & 0.28 & [67] \\
\hline
\end{tabular}


Table 2. Cont.

\begin{tabular}{|c|c|c|c|c|c|c|c|c|c|c|c|}
\hline G. optiva & Leaves & Pakistan & Water & Antibacterial & $\begin{array}{c}\text { S. } \\
\text { pneumoniae }\end{array}$ & $\begin{array}{c}\text { Zone of } \\
\text { inhibition } \\
10 \mathrm{~mm}\end{array}$ & 0.21 & Cephradine & $\begin{array}{l}\text { Zone of inhibition } \\
25 \mathrm{~mm}\end{array}$ & 0.30 & [27] \\
\hline G. asiatica & $\begin{array}{l}\text { Bark } \\
\text { Fruit }\end{array}$ & Pakistan & Ethanol & Antibacterial & $\begin{array}{l}\text { Proteus } \\
\text { vulgaris }\end{array}$ & $\begin{array}{c}\text { Zone of } \\
\text { inhibition } \\
7.33 \mathrm{~mm}\end{array}$ & 0.85 & Moxifloxacin & $\begin{array}{l}\text { Zone of inhibition } \\
16 \mathrm{~mm}\end{array}$ & NG & [65] \\
\hline G. asiatica & Leaves & Pakistan & Ethanol & Antifungal & $\begin{array}{c}\text { Fusarium } \\
\text { solani }\end{array}$ & $\begin{array}{c}\text { MIC was } \\
>10 \mathrm{mg} / \mathrm{mL}\end{array}$ & NG & Itraconazole & $\begin{array}{l}\text { MIC was } \\
12 \mathrm{mg} / \mathrm{mL}\end{array}$ & 0.34 & [63] \\
\hline G. asiatica & Fruit & Pakistan & Methanol & Antifungal & $\begin{array}{l}\text { Aspergillus } \\
\text { niger }\end{array}$ & $\begin{array}{c}\text { Zone of } \\
\text { inhibition } \\
40 \mathrm{~mm}\end{array}$ & 0.55 & NG & NG & NG & [64] \\
\hline G. asiatica & Fruit & Pakistan & Methanol & Antifungal & $\begin{array}{l}\text { Penicillium } \\
\text { notatum }\end{array}$ & $\begin{array}{c}\text { Zone of } \\
\text { inhibition } \\
35 \mathrm{~mm}\end{array}$ & 0.90 & NG & NG & NG & [64] \\
\hline G. asiatica & Leaves & India & Acetone & Antifungal & $\begin{array}{l}\text { Candida } \\
\text { glabrata }\end{array}$ & $\begin{array}{c}\text { Zone of } \\
\text { inhibition } \\
28 \mathrm{~mm}\end{array}$ & 1.53 & NG & NG & NG & [51] \\
\hline G. asiatica & Leaves & India & Acetone & Antifungal & $\begin{array}{l}\text { Aspergillus } \\
\text { niger }\end{array}$ & $\begin{array}{c}\text { Zone of } \\
\text { inhibition } \\
25 \mathrm{~mm}\end{array}$ & 0.58 & NG & NG & NG & [51] \\
\hline G. asiatica & Leaves & Pakistan & Water & Antifungal & $\begin{array}{l}\text { Rhizoctonia } \\
\text { solani }\end{array}$ & $\begin{array}{c}86 \% \\
\text { inhibition }\end{array}$ & 2 & NG & NG & NG & [68] \\
\hline G. asiatica & Leaves & Pakistan & Water & Antifungal & $\begin{array}{l}\text { Fusarium } \\
\text { oxysporum }\end{array}$ & $\begin{array}{c}62 \% \\
\text { inhibition }\end{array}$ & 1.5 & NG & NG & NG & [68] \\
\hline G. asiatica & Leaves & Pakistan & Water & Antifungal & $\begin{array}{c}\text { Macrophomina } \\
\text { phaseolina }\end{array}$ & $\begin{array}{c}81 \% \\
\text { inhibition }\end{array}$ & 4.1 & NG & NG & NG & [68] \\
\hline
\end{tabular}


Table 2. Cont.

\begin{tabular}{|c|c|c|c|c|c|c|c|c|c|c|c|}
\hline \multicolumn{12}{|c|}{ Antidiabetic properties of the Grewia species } \\
\hline Species & Plant Part & Origin & $\begin{array}{c}\text { Extraction } \\
\text { Solvent }\end{array}$ & Assay & $\begin{array}{c}\text { Negative } \\
\text { Control }\end{array}$ & Std Dev & Positive Control & Std Dev & Activity of Extract & Std Dev & References \\
\hline G. asiatica & Fruit & Egypt & Ethanol & Rats model & $\begin{array}{c}\text { Serum } \\
\text { glucose } \\
\text { level was } \\
150\end{array}$ & 10.9 & NG & NG & $\begin{array}{c}\text { Serum glucose } \\
\text { level was } 105 \text { at } \\
200 \mathrm{mg} / \mathrm{kg} \text { of } \\
\text { extract }\end{array}$ & 10.4 & [69] \\
\hline G. asiatica & Leaf & India & Ethanol & Rats model & $\begin{array}{c}\text { Serum } \\
\text { glucose } \\
\text { level was } \\
227.3\end{array}$ & 5.9 & $\begin{array}{c}\text { Serum glucose } \\
\text { level was } 201 \text { at } \\
\text { Glibenclamide } \\
10 \mathrm{mg} / \mathrm{kg}\end{array}$ & 6.3 & $\begin{array}{c}\text { Serum glucose } \\
\text { level was } 205 \text { at } \\
200 \mathrm{mg} / \mathrm{kg} \text { of } \\
\text { extract }\end{array}$ & 7.1 & [70] \\
\hline G. asiatica & Bark & Bangladesh & Ethanol & Rats model & $\begin{array}{c}\text { Serum } \\
\text { glucose } \\
\text { level was } \\
14.9\end{array}$ & 3 & $\begin{array}{l}\text { Serum glucose } \\
\text { level was } 5.9 \text { at } \\
\text { Metformin } \\
150 \mathrm{mg} / \mathrm{kg}\end{array}$ & 3 & $\begin{array}{l}\text { Serum glucose } \\
\text { level was } 7.1\end{array}$ & 2.5 & {$[66]$} \\
\hline G. asiatica & Leaf & Pakistan & Methanol & $\alpha$-Amylase & NG & NG & $\begin{array}{c}98 \% \text { inhibition of } \\
\alpha \text {-amylase at } \\
\text { Acarbose } \\
0.1 \mu \mathrm{g} / \mathrm{mL}\end{array}$ & NG & $\begin{array}{c}80 \% \text { inhibition at } \\
500 \mu \mathrm{g} / \mathrm{mL} \text { of } \\
\text { extract }\end{array}$ & NG & {$[71]$} \\
\hline G. asiatica & Leaf & Pakistan & Methanol & $\begin{array}{c}\alpha- \\
\text { Glucosidase }\end{array}$ & NG & NG & $\begin{array}{c}98 \% \text { inhibition of } \\
\alpha \text {-glucosidase at } \\
\text { Acarbose } \\
0.1 \mu \mathrm{g} / \mathrm{mL}\end{array}$ & NG & $\begin{array}{c}80 \% \text { inhibition at } \\
500 \mu \mathrm{g} / \mathrm{mL} \text { of } \\
\text { extract }\end{array}$ & NG & {$[71]$} \\
\hline G. asiatica & Fruit & India & Aqueous & $\begin{array}{c}\alpha- \\
\text { Glucosidase }\end{array}$ & NG & NG & $\begin{array}{c}\text { Acarbose } \\
\text { exhibited } \mathrm{IC}_{50} \\
0.006 \mu \mathrm{g} / \mathrm{mL} \text { in } \\
\alpha \text {-glucosidase } \\
\text { inhibition }\end{array}$ & NG & $\mathrm{IC}_{50} 8.93 \mathrm{mg} / \mathrm{mL}$ & NG & [72] \\
\hline
\end{tabular}


Table 2. Cont.

\begin{tabular}{|c|c|c|c|c|c|c|c|c|c|c|c|}
\hline G. asiatica & Fruit & India & Aqueous & $\alpha$-Amylase & NG & NG & $\begin{array}{c}\text { Acarbose } \\
\text { exhibited IC } \mathrm{I}_{50} \\
0.83 \mu \mathrm{g} / \mathrm{mL} \text { in } \\
\alpha \text {-amylase } \\
\text { inhibition } \\
\text { Inhibition }\end{array}$ & NG & $\mathrm{IC}_{50} 0.41 \mathrm{mg} / \mathrm{mL}$ & NG & [72] \\
\hline G. asiatica & Pomace & India & $\begin{array}{l}20 \% \text { Hydro- } \\
\text { methanol }\end{array}$ & $\alpha$-Amylase & NG & NG & $\begin{array}{c}\mathrm{IC}_{50} 0.39 \mu \mathrm{g} / \mathrm{mL} \\
\text { in } \alpha \text {-amylase } \\
\text { inhibition }\end{array}$ & NG & $\mathrm{IC}_{50} 45.7 \mathrm{mg} / \mathrm{mL}$ & NG & [30] \\
\hline G. asiatica & Pomace & India & $\begin{array}{l}20 \% \text { Hydro- } \\
\text { acetone }\end{array}$ & $\alpha$-Amylase & NG & NG & $\begin{array}{c}\mathrm{IC}_{50} 0.39 \mu \mathrm{g} / \mathrm{mL} \\
\text { in } \alpha \text {-amylase } \\
\text { inhibition }\end{array}$ & NG & $\mathrm{IC}_{50} 85.2 \mathrm{mg} / \mathrm{mL}$ & NG & [30] \\
\hline G. asiatica & Fruit & Pakistan & Methanol & $\begin{array}{l}\text { Non-diabetic } \\
\text { human } \\
\text { model }\end{array}$ & NG & NG & NG & NG & $\begin{array}{l}1.4 \% \text { reduction in } \\
\text { blood glucose } \\
\text { level }\end{array}$ & NG & [73] \\
\hline
\end{tabular}

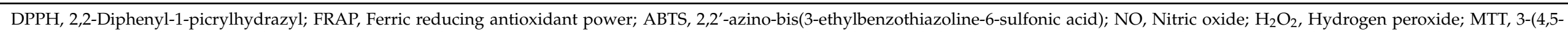

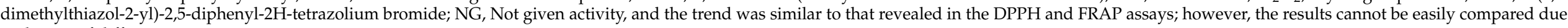
to the use of different units. 


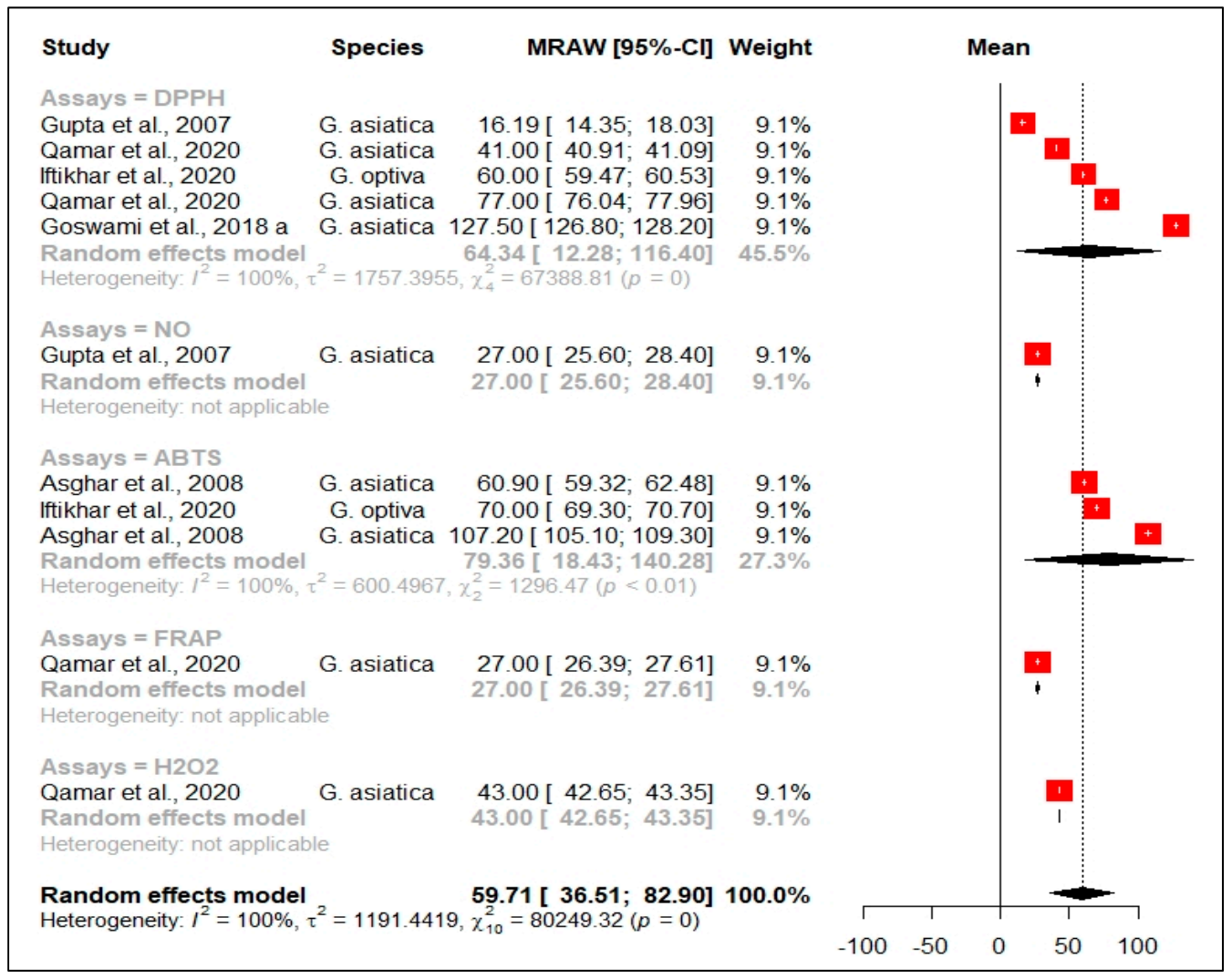

(a)

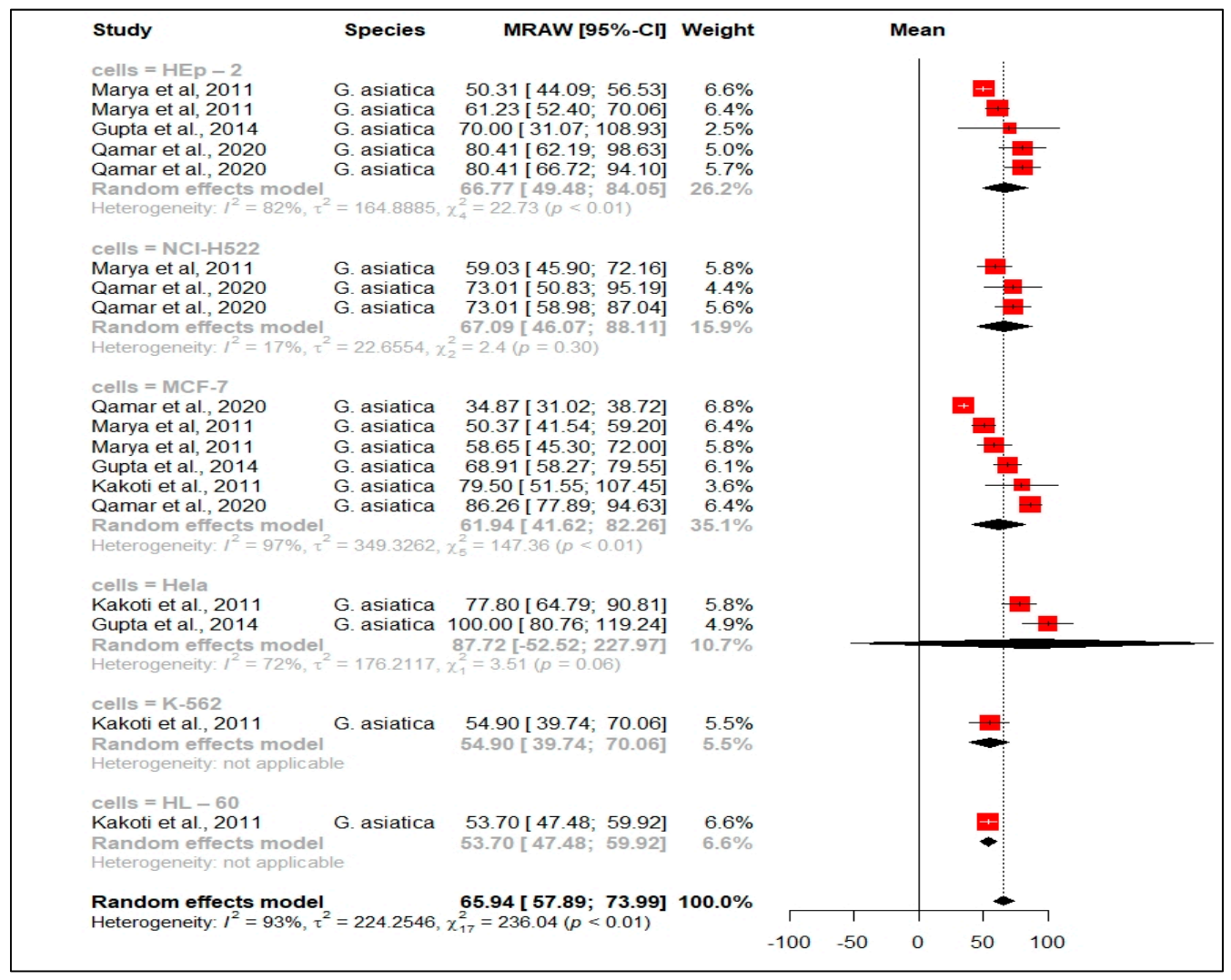

(b)

Figure 5. Cont. 


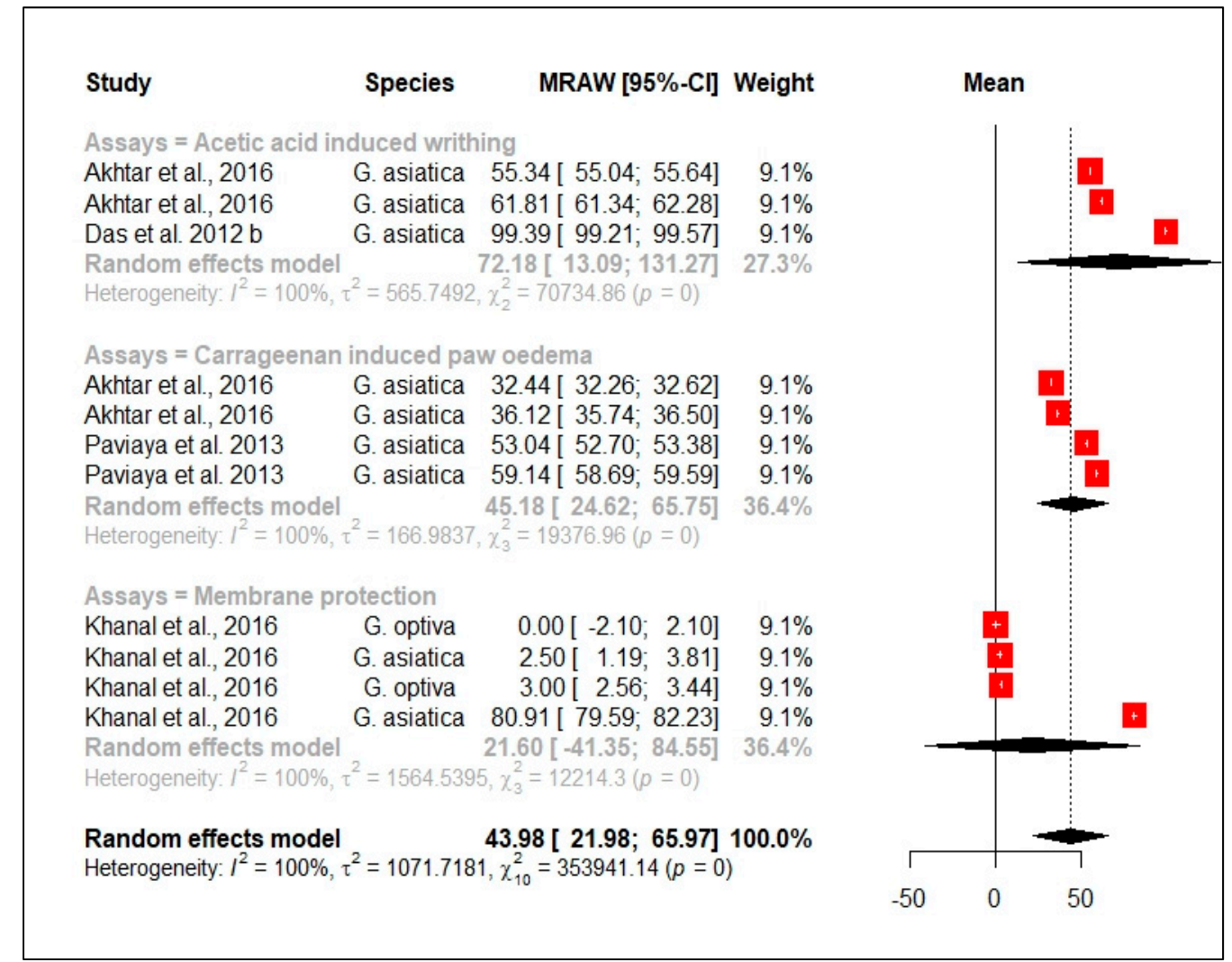

(c)

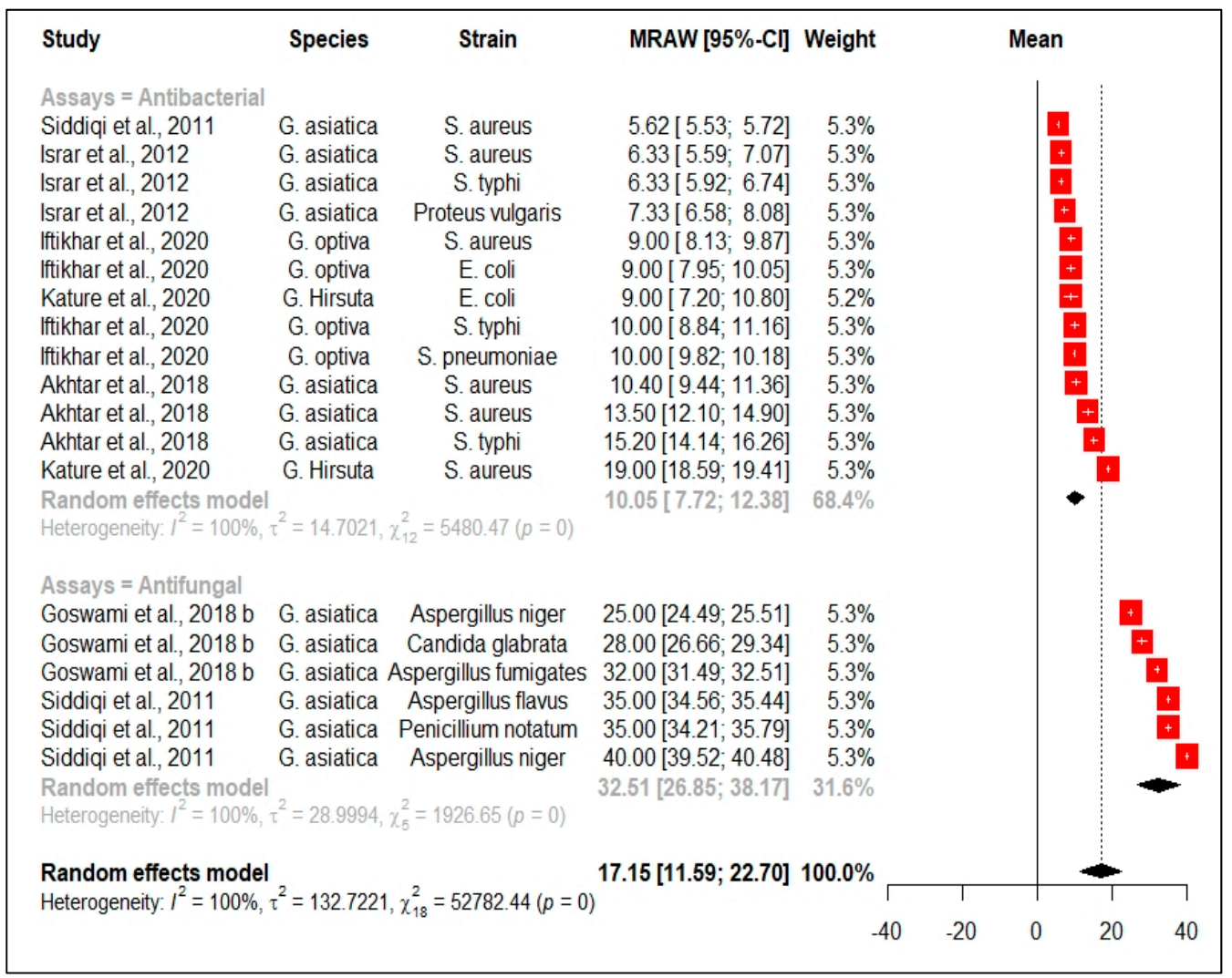

(d)

Figure 5. Meta-analysis of the antioxidant (a), anticancer (b), anti-inflammatory (c), and antimicrobial (d) activities $[24,27,30,44,46,51,60,61,68,69,72,74-77]$. 


\subsubsection{Anticancer Properties}

Despite the overwhelming research response by researchers, cancer still represents the second leading cause of death and is trending towards becoming the leading cause in the elderly [78]. Besides the tremendous development in anticancer therapies and drugs, the prevention of tumor generation by adopting a healthy lifestyle is generally considered as an effective strategy to reduce cancer risk. It is well established that diets rich in fruit and vegetables are useful in cancer prevention by virtue of their content of a wide variety of phytochemicals [79]. Their preventive activity goes beyond the antioxidant capacity, and includes effects on the expression of oncogenes, tumor suppressor genes and transcription factors, and on cell cycle and apoptosis [80,81].

Six studies were reported from 2011 to 2020 that evaluated the anticancer potential of the Grewia species, wherein five articles reported the anticancer effects of G. asiatica, one study focused on G. lasiocarpa, and all the studies employed the MTT assay as an index of cell proliferation. Among five studies on G. asiatica, two studies used a methanolic extract from the leaves, one study used the methanolic extract from fruit residues, one study used an aqueous methanol extract from fruit, one study presented the comparison between the aqueous extract from both fruits and leaves, and the last study used stem bark of G. lasiocarpa. In all studies, samples were prepared by initially drying the fruit/leaves/stems under shade and then were extracted with the previously mentioned solvents.

Five studies were included in the meta-analysis of the anticancer activities of various Grewia species, as summarized in Figure 5b, except for one study reported by Dattani et al. (2011) [56] which was excluded as the results were presented in different units. The meta-analysis revealed that the Grewia species showed anticancer activities $\left(\mathrm{MRAW}=65.94,95 \% \mathrm{CI}=57.89-73.99, p<0.01, \mathrm{I}^{2}=93 \%\right.$ ) overall. However, a detailed submeta-analysis for specific cancer cell lines showed that G. asiatica exerted profound effects against the proliferation of HepG2 cells (MRAW $=66.77,95 \% \mathrm{CI}=49.48-84.05, p<0.01$, $\left.\mathrm{I}^{2}=82 \%\right)$, NCI-H $522\left(\mathrm{MRAW}=67.09,95 \% \mathrm{CI}=46.07-8.11, p<0.30, \mathrm{I}^{2}=70 \%\right)$, MCF$7\left(\mathrm{MRAW}=61.94,95 \% \mathrm{CI}=41.62-82.26, p<0.01, \mathrm{I}^{2}=97 \%\right)$, and HeLa $(\mathrm{MRAW}=87.72$, $95 \% \mathrm{CI}=-52.52-227.97, p<0.06, \mathrm{I}^{2}=72 \%$ ). In contrast, there was only one study that discussed the effects of the G. asiatica fruit against K562 and HL-60 (human leukemia) cells; therefore, a meta-analysis was not possible for that study.

Marya et al. [55] observed significant cytotoxic effects of the aqueous extract from the G. asiatica fruit against HEp-2 (larynx cancer), NCI-H522 (lung cancer), and MCF-7 (breast cancer) with $\mathrm{IC}_{50}$ of $50.31 \mu \mathrm{g} / \mathrm{mL}, 59.03 \mu \mathrm{g} / \mathrm{mL}$ and $58.65 \mu \mathrm{g} / \mathrm{mL}$, respectively. However, notable activity of the aqueous extract from the G. asiatica leaves was observed in the aforementioned study against HEp-2 and MCF-7 cancer cell lines with $\mathrm{IC}_{50}$ extracts of $61.23 \mu \mathrm{g} / \mathrm{mL}, 50.37 \mu \mathrm{g} / \mathrm{mL}$, respectively. Dattani et al. [56] recorded a similar response of ethanolic extracts from the G. asiatica fruit against NCI-H522 and MCF-7 cells while the extracts appeared to be ineffective against a cervical cancer cell line (HeLa) and HEp-2. Moreover, the intraperitoneal administration of methanolic extracts from the G. asiatica fruit inhibited the growth of Ehrlich's ascites carcinoma (EAC) cells resulting in a significant increase in the life span of tumor-bearing animals and exerted cytotoxic activity toward four human cancer cells i.e., HL-60, K-562, MCF-7, and HeLa with an $\mathrm{IC}_{50}$ of 53.7, 54.9, 199.5, and $177.8 \mu \mathrm{g} / \mathrm{mL}$, respectively [57]. With regard to the pomace extract from G. asiatica, this was shown to elicit a significant cytotoxic activity against MCF-7 with an $\mathrm{IC}_{50}$ of $68.91 \mu \mathrm{g} / \mathrm{mL}$, and a less remarkable activity towards bone sarcoma cells (MG-63), HeLa, and hepatocellular carcinoma cells (HepG2) [30]. A recent study illustrated that the aqueous methanol extract from G. asiatica to be more effective against breast cancer, lung cancer, and laryngeal cancer cell lines with $\mathrm{IC}_{50}$ of $34.87 \mu \mathrm{g} / \mathrm{mL}, 73.01 \mu \mathrm{g} / \mathrm{mL}$, and $80.41 \mu \mathrm{g} / \mathrm{mL}$, respectively suggesting antitumor claims for the G. asiatica [24]. However, the stem, bark, leaves, and pulp extracts from G. asiatica, when analyzed for cytotoxic potential by using a brine shrimp lethality assay and a hemagglutination assay, failed to show a significant cytotoxic response [82]. The last study [15] reported anticancer effects of the 
pure compound lupeol i.e., isolated from the stem bark of G. lasiocarpa against HEK293 (human embryonic kidney), HeLa, and MCF-7 cells.

\subsubsection{Anti-Inflammatory Activity}

The therapeutic role of medicinal plants alone or as adjuncts to conventional treatments, is firmly recognized. This notion, along with the relatively low cost of medicinal plants, has been a reason to promote their use in poor countries where people have restricted access to expensive drugs [83,84]. Inflammation is a fundamental and highly orchestrated physiological defensive process against noxious factors such as infections, exposure to toxicants, allergens, and other stimuli. Inflammation is often associated with pain that is quite often mediated with nonsteroidal drugs (NSAIDS) such as corticosteroids which possess remarkable anti-inflammatory activity and analgesics such as opioids and anticonvulsants $[85,86]$. However, the prolonged use of these drugs is discouraged due to their adverse effects such as severe gastric lesions, digestive system disorders, nausea, urinary retention, and dependence on opioids.

Six studies were included in this category from 2012 to 2020; five of them focused on G. asiatica whereas five articles focused on fruit parts and one study focused on the stem bark. The last study provided a comparison between the $n$-hexane extracts from G. asiatica and G. optiva for their protective effects against hypotonicity-induced lysis i.e., membrane stabilization. Lyophilization was the most commonly employed technique for sample preparation. The analgesic activity was evaluated using acetic acid-induced writhing and hot plate methods. Antipyretic activity was evaluated using the Brewerís yeast-induced pyrexia method, in vivo anti-inflammatory activity was recorded using carrageenan-induced paw edema, and in vitro anti-inflammatory activity was examined using the human RBC membrane stabilization method.

Four studies were included in the meta-analysis of the anti-inflammatory activities of two Grewia species i.e., asiatica and optiva, as summarized in Figure 5c, except one study reported by Bajpai et al. [61], where the results were not presented in any unit. The meta-analysis revealed that the Grewia species showed notable antinociceptive and anti-inflammatory activity (MRAW $=43.98,95 \% \mathrm{CI}=21.98-65.97, p=0.0, \mathrm{I}^{2}=100 \%$ ) overall. However, a detailed sub meta-analysis suggested notable antinociceptive activities against acetic acid-induced writhing (MRAW $=72.18,95 \% \mathrm{CI}=13.09-131.27$, $p=0.0, \mathrm{I}^{2}=100 \%$ ), anti-inflammatory activity against carrageenan-induced paw edema $\left(\mathrm{MRAW}=45.18,95 \% \mathrm{CI}=24.61-65.75, p=0.0, \mathrm{I}^{2}=100 \%\right.$ ), and protection of the membrane against heat-induced hemolysis (MRAW $=21.6,95 \% \mathrm{CI}=-41.35-84.55, p=0.0, \mathrm{I}^{2}=100 \%$ ).

Das et al. [72] evaluated the anti-pain activity of aqueous extracts from G. asiatica fruits using the acetic acid-induced writhing ( $n=35$, trial duration $30 \mathrm{~min}$ ), tail immersion ( $n=35$ trail duration was $10,30,60 \mathrm{~min}$ ), and hot plate methods $(n=35$, trial duration $10 \mathrm{~min}$ ) in rats. Aqueous extracts of the G. asiatica fruit ( $200-300 \mathrm{mg} / \mathrm{kg}$ body weight) were found to attenuate the pain induced by acetic acid in the writhing test, tail immersion, and hot plate tests. Paviaya et al. [60] reported the analgesic efficacy of aqueous and methanolic extracts of G. asiatica bark in the hot plate test ( $n=30$, trial duration was $0,30,90,190 \mathrm{~min}$ ) and the writhing response test $(n=30$, trial duration was $30 \mathrm{~min}$ ). Similar studies also demonstrated that the methanolic and aqueous fruit extracts of G. asiatica at doses between 300 and $500 \mathrm{mg} / \mathrm{kg}$ counteracted the fever induced by lipopolysaccharide $(n=25$, trail duration was 30, 60, $90 \mathrm{~min}$ ) and brewer's yeast ( $n=25$, trail duration was $1,2,3,18 \mathrm{~h}$ ) in rats, respectively [58,59]. The most recent study by Qamar et al. [24] found that $100 \%$ methanol and $50 \%$ aqueous methanol extracts of G. asiatica fruits protected the animals under experimentation from the painful stimulation of formalin $(n=40$, trial duration was $0-25 \mathrm{~min}$ ) in a dose-dependent manner with the maximum effect being $62.9 \%$ and $62.6 \%$, respectively at $400 \mathrm{mg} / \mathrm{kg} /$ body weight. Similarly, methanol and aqueous methanol extracts of the G. asiatica fruit subjected to a glutamate-induced $(n=40$, trial duration was $0-25 \mathrm{~min}$ ) nociceptive response assessment in a mice model showed a significant anti-nociceptive effect from G. asiatica in comparison to the control and standard drug [24]. 
The anti-inflammatory potential of G. asiatica has also been extensively investigated. The data demonstrating the efficacy of the various anatomical fractions of G. asiatica such as bark as anti-inflammatory agents were significant when tested against carrageenaninduced paw oedema ( $n=30$ trail duration was $3 \mathrm{~h}$ ) in rats. The authors confirmed that bark methanol and aqueous extracts were significant factors that attenuated paw edema at $400 \mathrm{mg} / \mathrm{kg}$ as $59.14 \%$ and $53.04 \%$, respectively, while the response was quite comparable to that of indomethacin $(64.02 \%$ reduction at $10 \mathrm{mg} / \mathrm{kg})$ [60]. Methanol extracts of G. asiatica fruits were also screened for their possible anti-inflammatory activity on carrageenaninduced paw edema in rats at an oral dose level of 250 and $500 \mathrm{mg} / \mathrm{kg}$, orally. The extract showed significant anti-inflammatory activity at both doses [61].

The methanol and aqueous extracts of $G$. asiatica fruits exerted anti-inflammatory activity against carrageenan-induced paw edema $(n=25$, trail duration was $1-3 \mathrm{~h})$ in a dose-dependent manner at $36.1 \%$ and $32.4 \%$ at $500 \mathrm{mg} / \mathrm{kg}$, respectively in comparison to the standard indomethacin, which exerted $36.4 \%$ inhibition at $10 \mathrm{mg} / \mathrm{kg}$ [59]. Feeding $100 \%$ methanolic extracts of G. asiatica fruits to mice at the rate of $400 \mathrm{mg} / \mathrm{kg}$ b.w., inhibited formaldehyde ( $n=40$, trail duration was $0-25 \mathrm{~h}$ ) and carrageenan-induced paw oedema ( $n=40$, trail duration was $1-3 \mathrm{~h}$ ) by $74 \%$ and $71 \%$, respectively, while the inhibition rate was $88 \%$ with indomethacin within $3 \mathrm{~h}$ of extract/standard drug feeding at $100 \mathrm{mg} / \mathrm{kg}$. Further, a 50\% methanolic extract also indicated increased efficacy against Prostaglandin $\mathrm{E}_{2}$ (PGE2)-induced paw edema (68.7\% inhibition at $400 \mathrm{mg} / \mathrm{kg}$ (b.w.) in $120 \mathrm{~min}$ of extract administration) in comparison with the control while indomethacin presented a relatively higher rate of inhibition to PGE2-induced paw edema i.e., $79 \%$ at $100 \mathrm{mg} / \mathrm{kg}$ [24]. The last study reported that the traditional use of $G$. asiatica $n$-hexane extracts as anti-inflammatory ingredients was justified [62] on account of the extract's ability to significantly stabilize human red blood cells in comparison with diclofenac potassium.

\subsubsection{Antidiabetic Activity}

Type 2 diabetes has emerged as an important health problem within the 21st century [87]. Ever increasing infiltration trends of diabetes is one of the major health-threatening issues in both developed and developing societies and individuals [88]. Hitherto, one human, five animal, and three in vitro studies have been conducted to investigate the antidiabetic potential of G. asiatica from 2011 to 2016 and no other Grewia species have been explored under the mentioned category so far. Among nine reported studies, 3, 3, 1, 1 focused on leaves, fruits, bark, and pomace, respectively, and one study presented a comparison of the antidiabetic activity of the fruit, stem, and bark ethanolic extracts of G. asiatica.

Interestingly, the oral supplementation of an ethanol extract of the G. asiatica bark in alloxan-induced diabetic rats $(n=20$, trial duration was $0-120 \mathrm{~min}$ ) significantly attenuated the blood glucose levels and increased the survival rate of diabetic rats when compared with metformin-treated rats [89]. Likewise, ethanolic extracts of G. asiatica significantly lowered the blood glucose level in alloxan-induced diabetic rats $(n=36$, trail duration was $0-7 \mathrm{~h}$ ), and appeared to be more effective than glibenclamide used as a reference antidiabetic drug [70]. Another study on streptozotocin-induced diabetic rats $(n=36$, trail duration was $0-24 \mathrm{~h}$ ) recorded that the oral administration of extracts of the G. asiatica leaves at the rate of $\sim 500 \mathrm{mg} / \mathrm{kg}$ b.w. for 21 days efficiently shortened and reduced blood glucose spikes in rats previously exposed to overloads of glucose, and considerably increased the glucose tolerance in normal rats [90].

Likewise, Khattab et al. [69] recorded normalized glycemia in streptozotocin-induced rats fed with $G$. asiatica fruit extracts. The study ( $n=40$, trail duration was 4 weeks) recorded reduced serum cytokine IL- $1 \beta$ and TNF- $\alpha$ levels, decreased pancreas malondialdehyde (MDA) levels, and normalized glycemia concomitantly with a higher accumulation of liver glycogen and increased liver and pancreas glutathione (GSH) and superoxide dismutase (SOD) enzyme activities. Moreover, the inhibitory properties of the aqueous extracts of the $G$. asiatica fruit against $\alpha$-glucosidase and $\alpha$-amylase activity with $\mathrm{IC}_{50}$ of 8.93 and 
$0.41 \mathrm{mg} / \mathrm{mL}$, respectively were also reported by Das et al. [58] The inhibitory properties of the aqueous methanol extract of $G$. asiatica fruit residues with $\mathrm{IC}_{50}$ of $45.70 \mathrm{mg} / \mathrm{mL}$ against $\alpha$-Amylase were recorded and were more promising when compared with the extracts of B. vulgaris, A. comosus, A. lachoocha, and A. heterophyllus fruit [30]. Notably, clinical trials revealed that $G$. asiatica fruit extracts have a moderate hypoglycemic effect on a nondiabetic human model. Furthermore, when tested in vitro with glucose, the fruit showed neutralizing effects on glucose-induced reactive oxygen species (ROS) suppression [73].

\subsubsection{Radioprotective and Hepatoprotective Potential}

Exposure to ionizing radiations is unsafe for human health, even when used in therapeutics e.g., radiotherapy against cancer cells may cause severe side effects to irradiated patients.

Eight studies were reported in this category and all studies explored the edible portion of G. asiatica. Seven of them performed the extraction with methanol and one study employed ethanol extraction. Methanol extract supplementation was reported to protect mice brain lipids against radiation-induced ( $n=120$, trail duration was 1-30 days) oxidation and was shown to improve the GSH content by $14.3 \%$ [91]. G. asiatica fruit extracts were also shown to significantly protect against the deleterious effects of whole-body irradiation in mice [92]. Another study by Sisodia and Singh (2009) [93] reported that G. asiatica fruit extracts prevented radiation-induced memory and learning deficits in addition to known histopathological, biochemical, and behavioral ameliorative effects. Numerous studies advocated a G. asiatica fruit-enriched diet to reduce lipid peroxidation rates and serum cholesterol, and to restore the normal levels of GSH, glutathione peroxide (GSH-Px), sugars, and proteins in irradiated mice models [74,94,95]. A histopathological and biochemical investigation of the hepatic tissues of X-ray-irradiated G. asiatica extract-fed mice demonstrated hepatoprotective effects $[2,96]$. Radioprotective effects were also noticed in histopathological specimens of mice testis where irradiation resulted in lower spermatogonia " $\mathrm{A}$ ", spermatogonia "B", spermatocytes and spermatid count when compared with animals irradiated after supplementation with G. asiatica fruit extracts [75].

\subsubsection{Antimicrobial Properties}

Plants serve as an important source of novel medicinal substances [76,97]. Sufficient information is available to confirm the anti-infective role of bioactive compounds of natural origin. For centuries, the use of herbal drugs has been extensively recommended to modulate various opportunistic infections. Flavonoids isolated from ethnopharmacologically established plants are considered to be effective antimicrobial substances against a wide variety of microorganisms $[77,98]$. Nine studies were reported in the mentioned category from 2011 to 2020, wherein two studies performed both antibacterial and antifungal activities, five studies reported only antibacterial activities, and lastly, two studies only evaluated the antifungal potential. Out of nine total reported articles, G. asiatica was the most commonly explored i.e., G. asiatica was the focus in six studies and G. optiva, G. lasiocarpa, and G. hirsuta were the focus in 1, 1, and 1 studies, separately. Five studies focused on leaves, two studies focused on fruit, and two studies used stem bark to evaluate the antibacterial and antifungal properties of the Grewia species. Researchers have shown that crude extracts of the Grewia spp. have valuable antibacterial activities predominately associated with their high flavonoid content. Beside the fruit fraction, the leaves and stem bark of G. asiatica have also been suggested to possess antimicrobial potential $[27,63-66,68]$.

Six studies were included in the meta-analysis of antimicrobial potential including three Grewia species i.e., asiatica, optiva, and hirsuta as summarized in Figure 5d, except three studies reported by Akwu et al. (2020) [15], Zia et al. (2011) [63], Dawar et al. (2020) [68] wherein standard deviation was not mentioned. The meta-analysis revealed that the Grewia species showed notable antibacterial and anti-fungal activity (MRAW $=17.15$, $95 \% \mathrm{CI}=11.59-22.70, p=0.0, \mathrm{I}^{2}=100 \%$ ) overall. However, the detailed sub meta-analysis suggested showed notable antibacterial $(\mathrm{MRAW}=10.05,95 \% \mathrm{CI}=7.72-12.38, p=0.0$, 
$\mathrm{I}^{2}=100 \%$ ) and anti-fungal (MRAW $=32.51,95 \% \mathrm{CI}=26.85-38.17, p=0.0, \mathrm{I}^{2}=100 \%$ ) activities.

Flavonoids and flavonoid-rich fractions isolated from the peel and pulp of G. asiatica caused significant inhibition against Gram-positive and Gram-negative bacterial strains. Staphylococcus aureus was reported to be the most susceptible and Bacillus subtilis was reported to be the least susceptible among the Gram-positive bacterial strains while Salmonella typhi were the most susceptible and Escherichia coli ranked among least susceptible among the Gram-negative bacterial strains [64].

The antibacterial activity of the methanolic extract of the G. asiatica leaves has been reported against Staphylococcus aureus and Salmonella typhi while the aqueous extract of G. asiatica leaves was only found to be effective against S. aureus [66]. G. asiatica fruit extracts can inhibit Gram-negative bacteria through their bioactive compounds such as flavonoids, alkaloids, and saponins without necessarily penetrating into the microbial cell [99]. The potent antibacterial activity of G. asiatica leaf extracts has also been shown against eight different bacterial strains, i.e., Proteus mirabilis, Citrobacter sp., Pseudomonas aeruginosa, Escherichia coli, Salmonella typhi, Micrococcus luteus, Staphylococcus aureus, and Bacillus subtilis [63]. Another study investigating the efficacy of the bark and fruit extracts of G. asiatica against four Gram-positive and six Gram-negative bacterial strains found that the extracts were more active toward S. aureus, E. coli, and Proteus vulgaris, and overall, were more active on Gram-positive strains as compared to Gramnegative bacteria [65]. Another study found the aqueous extract of G. optiva leaves to exert moderate inhibition against three different bacterial strains named S. aureus, E. coli, Salmonella typhi, and Streptococcus pneumoniae [27]. A seventy per cent methanol extract of G. hirsuta showed antibacterial activity against $S$. aureus and E. coli equivalent to the standard drug ciprofloxacin [67].

Ethanol extracts of G. asiatica leaves were reported to have good antifungal activity against nine fungal strains, namely, Aspergillus effusus, A. parasiticus, A. niger, Saccharomyces cerevisiae, Candida albicans, Yersinia aldovae, Fusarium solani, Macrophomina phaseolina, and Trichophyton rubrum [63]. Pathogenic fungi are responsible for huge crop production losses by perishing the roots system within plants. In vitro antifungal trials using paper disc and diffusion methods found that a $100 \%$ aqueous extract from the G. asiatica leaves induced significant inhibition against Rhizoctonia solani, Fusarium oxysporum, and Macrophomina phaseolina and consequently ameliorated the growth of bottle gourd and cowpea. Correspondingly, in vivo results disclosed that an addition of $1 \%$ of the powder of the G. asiatica leaves to organic matter considerably reduced the colonization of Macrophomina phaseolina, Rhizoctonia solani, and Fusarium spp. An even greater inhibition against colonization was offered by a $100 \%$ G. asiatica leaf extract when directly drenched into the soil. Further, seed treatment of food crops with a $100 \%$ leaf extract was reported to increase the bottle gourd and cowpea growth and notably suppressed fungal attack [68].

In an in vitro antiviral trial, a G. asiatica extract was sprayed on test plants at different concentrations (500, 1000, 1500, and $2000 \mu \mathrm{g} / \mathrm{mL}$ ) against ULCV (Urdbean leaf crinkle virus). Plants sprayed with $1000 \mu \mathrm{g} / \mathrm{mL}$ of a G. asiatica extract exhibited a minimum \% infection (34\%) as compared to the control which showed $90 \%$ infection, while notable activity against ULCV at concentrations of 1500 and $2000 \mu \mathrm{g} / \mathrm{mL}$ was observed [100]. The traditional use of the G. asiatica fruit and its decoctions as a remedy for digestive and urinary disorders is hence justifiably linked to the broad-spectrum antimicrobial activity of the fruit extracts against digestive and urinary tract pathogens such as Salmonella, E. coli, S. aureus, P. aeruginosa, and M. luteus. In a recent study by Goswami et al. (2018) [1], it was reported that a G. asiatica leaf acetone extract inhibited the activity of different pathogenic fungi including A. fumigatus and C. glabratai at a concentration of $35 \mathrm{mg} / \mathrm{mL}$.

\subsubsection{Antiemetic and Antimalarial Activities}

The antiemetic potential of an ethanol extract of the G. asiatica fruit was evaluated in a canine model at quite low doses while acute oral toxicity assays proved that extracts 
were safe for consumption at $200 \mathrm{mg} / \mathrm{kg}$ b.w., [101]. The referred study documented that administration of fruit extracts at $120 \mathrm{mg} / \mathrm{kg}$ b.w., was capable of inducing antiemetic effects in dogs and standard antiemetic drugs such as largactil and maxolon were shown to be active. Similar assays were performed on male chicks and the researchers suggested a dose-dependent inhibition, i.e., a decrease in the number of retches such that $39 \%$ inhibition was observed at $50 \mathrm{mg} / \mathrm{kg}$ while $\sim 60 \%$ inhibition was recorded with a $100 \mathrm{mg} / \mathrm{kg}$ supplementation of methanol fruit extracts of G. asiatica [71]. The literature confirmed the anti-malarial potential ( $69 \%$ inhibition) of the G. asiatica leaves assayed for their possible anti-malarial activity using Enoyl-ACP reductase inhibitory assay [102].

3.2.8. Other Activities: Immunomodulatory, Anti-Depressant, Anti-Neurodegenerative, Drug Delivery Polymers

The clinical data are still scarce on the immunomodulatory or immunoregulatory properties of G. asiatica. However, the presence of bioactive compounds bearing significant immune-mediating activities hints at future trends in immunological research related to the genus Grewia. As discussed earlier, the fruit extracts of G. asiatica carry a significant concentration of compounds such as quercetin, isovitexin, kaempferol, iso-liquiritigenin, and umbelliferone that have been extensively explored for their innate and adoptive immune response in inflammatory disorders [103-106]

A flavonoid-rich ethanol extract of the G. asiatica leaves was reported to exhibit immunomodulatory properties with satisfactory immunostimulation [10]. The notable sedative-hypnotic potential of methanol leaf extracts of G. asiatica in mice models was investigated and no toxicity was observed at a $300 \mathrm{mg} / \mathrm{kg}$ dose level [107]. Further studies explicated that G. asiatica methanol extracts improved scopolamine-induced learning and memory deficits in rats through the employment of behavior assessment models by reinstating the cytoarchitecture of effected neuronal cells, elevating neurotransmitter acetylcholine, and settling oxidative stress [11]. G. asiatica leaf fractions derived using petroleum ether and chloroform solvents showed considerable effectiveness against neurodegenerative ailments by inhibiting bovine brain acetylcholinesterase $\left(\mathrm{IC}_{50}=55.88 \mu \mathrm{g} / \mathrm{mL}\right)$ and human blood butyrylcholinesterase $\left(\mathrm{IC}_{50}=26.14 \mu \mathrm{g} / \mathrm{mL}\right)$ enzymes, respectively [12]. G. asiatica extracts have the ability to generate colloidal dispersions and viscous gel in water. The mucilage of G. asiatica was therefore tested as natural polymeric ingredients for gel formulation in drug design and suggested identical behavior to that of marketed formulation without negatively affecting drug release [108].

\section{Discussion}

From the results of the selected papers on the nutritional, phytochemical composition, and health-promoting potential of the Grewia species, our review identified primary metabolites (carbohydrate, protein and amino acids, fiber, fat, and fatty acids), minerals (calcium, sodium, iron, zinc, manganese), vitamins, and phytochemicals including flavonoids (flavones and anthocyanidins), phenolic acids, and triterpenes as major classes. These findings underscore the importance of this genus in maintaining a healthy and balanced diet. In comparison to the fruits, we discovered that the leaves and seeds have a better nutritional value and a larger quantity of bioactive substances. Although the composition varies according to the Grewia species, in general, the Grewia species are high in protein and fiber and have a low to intermediate fat and carbohydrate content, making them an excellent choice for people who are trying to lose weight.

Importantly, the contents of minerals such as calcium, potassium, sodium, iron, zinc, and manganese were found in notable amounts. The Institute of Medicine [109] recommended a daily allowance (RDA) of calcium as $1000 \mathrm{mg} /$ day for adults (19-50 years) wherein $100 \mathrm{~g}$ of the powder of the G. asiatica seed, G. tenax fruit, and G. villosa fruit can cover approximately $82 \%, 78 \%$, and $54 \%$, respectively of the RDA for calcium i.e., important for bone health. In the same manner, $100 \mathrm{~g}$ of the powder of G. asiatica seeds, G. villosa fruits, G. flavescence fruits, and G. tenax fruits can cover $100 \%$ of the RDA for iron. The Institute of Medicine [109] suggested $8 \mathrm{mg} /$ day iron for all age groups of men 
and postmenopausal women. That functions as a component of a number of proteins, including enzymes and hemoglobin, the latter being important for the transport of oxygen to tissues throughout the body for metabolism [110]. A hundred grams of the fruit powder of G. tenax, G. flavescence, and G. villosa can fulfil the RDA of zinc up to $23 \%, 13 \%$, and $19 \%$ as the zinc RDA for adults is $8 \mathrm{mg} /$ day for women and $11 \mathrm{mg} /$ day for men [109]. Zinc functions as a component of various enzymes in the maintenance of the structural integrity of proteins and in the regulation of gene expression [110]. The RDA for manganese is 2.3 and $1.8 \mathrm{mg} /$ day, respectively for adult men and women [109] and $100 \mathrm{~g}$ of $\mathrm{G}$. tenax fruit powder can cover $100 \%$ RDA of manganese whereas the powder of G. asiatica fruits and seeds can satisfy almost $50 \%$ of the RDA of manganese, which is involved in the formation of bones and in the amino acid, lipid, and carbohydrate metabolisms $[109,110]$. The RDA of ascorbic acid is $90 \mathrm{mg} /$ day as per the guidelines of the Food and Nutrition Board [111] and $100 \mathrm{~g}$ of the powder of the G. asiatica seeds can fulfill $5.7 \%$ of the RDA of vitamin C which is involved in the maintenance of normal connective tissue, wound healing and is needed for bone remodeling. It also acts as an antioxidant, opposes mutation in DNA, and is utilized in the treatment of several cancers [112]. A hundred grams of the fruit powder of G. tenax, G. flavescence, and G. villosa can contribute towards the adequate intake (AI) of potassium at $16.3 \%, 17.5 \%$, and $19.6 \%$, respectively, and the Food and Nutrition Board [111] suggested that the AI of potassium should be up to $4700 \mathrm{mg} /$ day. Potassium is responsible for acid-base control, maintaining osmotic pressure, nerve impulse transmission, muscular contraction, and the transport of carbon dioxide and oxygen [113,114]. The fatty acid profiling of two Grewia species i.e., G. asiatica and G. bicolor suggested the presence of saturated and unsaturated fatty acids. The polyunsaturated fatty acids are dominant in concentration as compared to saturated fatty acids. Polyunsaturated fatty acids in the diet should be increased since they contribute to lower total plasma cholesterol and protect against cardiovascular disease [115]. The intake of saturated fatty acids is linked to hypercholesterolemia and heart problems [116]. Both species had a moderate amount of saturated fatty acids such as palmitic acid (12.17-11.46\%) and stearic acid (5.01-5.77\%). Stearic acid has been demonstrated to worsen coronary artery disease by reducing high density lipoprotein cholesterol [116-118]. Studies have shown that palmitic acid is a potent inducer of DNA damage in insulin-secreting cell linen [119]. In contrast, unsaturated fatty acids including oleic acid and linoleic acid are reported in notable amounts in G. asiatica and G. bicolor seed oils ranging between $16.31-19.33 \%$ and $60.06 \%, 53.21 \%$, respectively. Oleic acid is an $\omega-9$ unsaturated fatty acid known to improve high-density lipoprotein (HDL) cholesterol while lowering low-density lipoprotein (LDL) cholesterol, lowering the risk of heart disease and atherosclerosis [120]. Oleic acid also prevents breast cancer cells from proliferating by inhibiting the growth of cancer-causing oncogenes HER-2/neu (erbB-2) expression [121]. Diets high in oleic acid have been demonstrated to decrease slightly obese women lose weight [122].

The phytochemicals identified in this review establish linkages to the underlying mechanisms on the health benefits of Grewia species. Most of the Grewia species compounds are known to have several health benefits, including antioxidant, anti-inflammatory, anticancer, hepatoprotective, radioprotective, and antimicrobial aspects. The antioxidant activity of the Grewia species lies mainly in its leaves, seeds, and pulp since they possess a higher radical scavenging ability while peel and stem bark extracts possess non-influential activity, confirmed in in vitro research mediated by their higher content on flavonoids, phenolic acids, and triterpenes. Regarding the anti-inflammatory properties, the fruit, bark, and leaf extracts of Grewia species and mainly the asiatica species controlled the pain mediation by suppressing the pro-inflammatory cytokines during in vivo assays and also imparted protection to red blood cell membrane against heat-induced hemolysis. In the anticancer analysis, fruit extracts exhibited remarkable activity followed by the leaf extracts, but the fruit residues and the stem bark extracts showed non-influential activity that is consistent with their bioactive metabolite potential. Studies have shown an improvement of glycemic profile by reducing serum glucose level, inhibiting $\alpha$-amylase, and $\alpha$-glucosidase evaluated 
using in vitro and in vivo research. The Grewia species may also facilitate antimicrobial activity associated with an inhibitory effect on Gram-positive and negative bacteria's growth and acting as an antifungal.

Quercetin, chlorogenic acid, caffeic acid, morin, and catechin were the compounds identified in more than one paper. A plethora of literature is available on the biological activities of the listed compounds from different plant sources. The literature cited below correlates the biological activity of the key compounds reported in this study with the existing set of information wherein these compounds have been individually explored for their antioxidant, anti-inflammatory, anticancer, and antimicrobial properties.

Quercetin retrieved from the methanol extract of Asparagus cochinchinensis had notable antioxidant activity with an $\mathrm{IC}_{50}$ of $14.52 \mu \mathrm{g} / \mathrm{mL}$ against free radicals, i.e., DPPH in contrast to standard vitamin $\mathrm{C}$ recorded with an $\mathrm{IC}_{50}$ of $10.49 \mu \mathrm{g} / \mathrm{mL}$ [123]. Notable free radical scavenging activity i.e., $6.35 \mu \mathrm{M}\left(\mathrm{SC}_{50}\right)$ was reported for chlorogenic acid isolated from the $n$-butanol fraction of the Eriobotrya japonica leaves [124]. Caffeic acid was reported to inhibit the DPPH free radicals with an $\mathrm{EC}_{50}$ of $111 \mathrm{mg} / \mathrm{mL}$ [125]. The compound was also found to be effective at reducing ferric iron with a FRAP value of $11.50 \mu \mathrm{mol} \mathrm{Fe}(\mathrm{II}) / \mathrm{g}$ d.w. Flavonoids (i.e., catechin, morin) and phenolic acids (i.e., caffeic acid, chlorogenic acid) were reported to exhibit notable antioxidant potential in four different biological assays including ORAC, FRAP, ABTS and DPPH [126]. Regarding the anti-inflammatory activity of the key identified compounds from various Grewia species, the intraperitoneal administration of quercetin at $80 \mathrm{mg} / \mathrm{kg}$ was reported to alter the carrageenan-induced paw edema in rats [127]. Methanolic extracts of Cheilanthes farinosa are potential carriers of chlorogenic acid. In a study by Yonathan et al. [128], the authors suggested that $10 \mathrm{mg} / \mathrm{mL}$ of chlorogenic acid had a remarkable anti-inflammatory activity against edema comparable with that of acetyl salicylic acid at a relatively higher concentration i.e., $200 \mathrm{mg} / \mathrm{mL}$. Inhibition of inflammation in carrageenan-induced paw edema using catechin in mice was reported to be approximately $28 \%$ at a dose of $30 \mathrm{mg} / \mathrm{kg}$ [129].

Plausible information on the anticancer activities of plants derived from bioactive compounds including flavonoids exists. This section briefly describes the findings of studies on the anticancer properties of plants originating from bioactive compounds. Quercetin isolated from the methanol extract of Asparagus cochinchinensis was reported to exhibit strong cytotoxicity against the HeLa cell line $\left(\mathrm{IC}_{50}\right.$ of $\left.5.78 \mu \mathrm{g} / \mathrm{mL}\right)$, followed by NCIH460 (IC 50 of $12.57 \mu \mathrm{g} / \mathrm{mL})$, Hep-G2 ( $\mathrm{IC}_{50}$ of $20.58 \mu \mathrm{g} / \mathrm{mL}$ ), and MCF-7 with an $\mathrm{IC}_{50}$ of $31.04 \mu \mathrm{g} / \mathrm{mL}$ [123]. Catechin isolated from green tea has been reported to inhibit the proliferation of lung cancer cells through the upregulation of the let-7 signaling pathway and the downregulation of the C-MYC, LIN-28 signaling pathway [130]. Previously, some reports have suggested that morin showed a diverse range of biological functions and has been reported to play essential roles in suppressing the growth of cancer cells (HepG2, HT29, and HCT116) as shown by Hussain et al. [131]. Morin-treated lung (A549) cells showed a decreased cell viability, colony formation, and migration rate when compared with the dimethyl sulfoxide-treated cells by suppressing the expression of miR-135b [132]. Chlorogenic acid derived from Laurocerasus officinalis was reported to exert notable inhibition against the breast cancer cell line (MCF-7) with $\mathrm{IC}_{50} 30.9 \mu \mathrm{g} / \mathrm{mL}$ [133]. Chlorogenic acid has been reported to inhibit the proliferation of human lung cancer (A549) cell lines by targeting annexin A2 in vitro and in vivo [134]. Chlorogenic acid and caffeic acid exhibited strong cytotoxic activity in vitro against A549 lung cancer cells, with an $\mathrm{IC}_{50}$ value of $9.8 \mu \mathrm{M}$ and $8.9 \mu \mathrm{M}$, which was similar to that of the positive control 5-fluorouracil i.e., $3.8 \mu \mathrm{M}$ [135]. In an earlier study by Garcia et al. [136], caffeic acid isolated from Scrophularia frutescens was reported to exhibit $\mathrm{ID}_{50}$ of $28.55 \times 10^{-3} \mu \mathrm{M}$ against the Hep- 2 cell line i.e., derived from a human epidermoid carcinoma of the larynx. A total of $10 \mu \mathrm{M}$ quercetin was recorded to reduce the expression of the immunoreactive P-glycoproteins (Pgp) in MCF-7 ADRresistant cells. Myricetin was also reported to suppress breast cancer metastasis through down-regulating the activity of the metalloproteinase matrix (MMP)-2/9 [137]. Another study by Rajendran et al. [138] reported that plant-based myricetin exhibited cytotoxic 
potential by inducing cell cycle arrest and ROS-reliant mitochondria-facilitated apoptosis in A549 lung cancer cells.

Regarding the antimicrobial activity, quercetin was reported to inhibit $S$. aureus and P. aeruginosa at dose of $20 \mathrm{mg} / \mathrm{mL}$ while $P$. vulgaris and E. coli were inhibited at a concentration $300 \mathrm{mg} / \mathrm{mL}$ and $400 \mathrm{mg} / \mathrm{mL}$, respectively [139]. Recently, a combined treatment of caffeic acid and UV-A LEDs effectively inactivated E. coli, S. Typhimurium, and L. monocytogenes in both a phosphate buffered saline (PBS) and commercial apple juice with no adverse effect on quality [140]. The antibacterial activity of morin was tested against three bacterial strains named E. coli, K. pneumoniae, S. aureus wherein at a concentration of $100 \mu \mathrm{g} /$ cylinder morin was effectively inhibited all strains [141].

\section{Conclusions}

The Grewia species contains biologically significant amounts of primary metabolites such as carbohydrates, protein and amino acids, ash and minerals, and fiber, but low contents of fats and fatty acids. These characteristics make them a good choice for a healthy life and for weight conscious people. Other than that, crude extracts of various parts i.e., the fruit, stem, bark, leaves, seeds, and identified/quantified compounds, including gallic acid, chlorogenic acid, caffeic acid, quercetin, morin, myricetin, vitexin, and catechins can be used for the development of nutraceuticals in order to address life-threatening ailments.

The present review discussed in detail the health-promoting potential of the various anatomical parts of all included Grewia species and the compounds extractable from those parts. Future studies should be conducted to isolate the identified compounds from G. asiatica and to conduct their clinical investigations and safety assessment. We also encourage researchers to work on other Grewia species for nutritional and phytochemical profiling so a comparison can be drawn, enabling an identification of the "best" species, from a bioactive and therapeutics point of view. A bibliometric analysis of co-authorships highlighted that most of the authors and regions of study are from South Asia, mainly India and Pakistan. So far, authors from India have collaborated and explored the antioxidant, anti-inflammatory, anticancer, radioprotective, and hepatoprotective aspects of the Grewia species, whereas authors from Pakistan have collaborated and evaluated antioxidant, anti-inflammatory, anticancer, antibacterial, antiemetic, and antimalarial activities. Surprisingly, the antibacterial, and antimalarial aspects were not explored by Indian authors, and the antidiabetic, hepatoprotective, and radioprotective potential were not explored by Pakistani authors as of the date of the present review. The mentioned loop could motivate the authors from other geographical regions, where the Grewia species also grows, to join the international ethno-geo-pharmacological investigation and to provide a comprehensive evaluation of the bio-potency by applying a unified methodology. Providing a unified specification of this potential Grewia genus and its parts (seeds, stems, roots, leaves and fruits) and identified compounds (quercetin, myricetin, morin, catechins, gallic acid, chlorogenic acid, caffeic acid, and others) would allow researchers to make a geobiopotency relationship based on plant growth in the different regions, exhibiting various high altitudes, sun exposure time, climate, soil type, humidity, and irrigation methods.

Supplementary Materials: The following are available online at https://www.mdpi.com/article/10 .3390/nu13124565/s1, Supplementary S1. PRISMA checklist. Supplementary S2. Search strategy used in the current review.

Author Contributions: Individual contributions from authors were as follows: Conceptualization, M.Q., S.A. and T.I.; investigation and resources, M.Q., T.E., Z.M.Z., S.A., M.W. and T.I.; writingoriginal draft preparation, M.Q., S.A., T.I., T.E. and Z.M.Z.; writing—review and editing, S.A., T.E., R.T.B. and Z.M.Z.; visualization and supervision, S.A., T.I. and T.E.; project administration, M.Q., S.A., T.E. and T.I. All authors have read and agreed to the published version of the manuscript.

Funding: The authors are grateful to the Higher Education Commission of Pakistan to financial support of the PhD thesis (Muhammad Qamar). The publication of this article was funded by the Open Access Fund of the Leibniz Universität Hannover, Germany. 
Institutional Review Board Statement: Not applicable.

Informed Consent Statement: Not applicable.

Data Availability Statement: Not applicable.

Conflicts of Interest: The authors declare no conflict of interest.

\section{References}

1. Goswami, S.; Jain, R.; Masih, H. Antifungal, antioxidant and DNA protection potential of Grewia asiatica L. leaves acetone extract. J. Pharmacogn. Phytochem. 2018, 7, 212-217.

2. Choudhary, I.M.; Siddiqui, J.; Abbaskhan, A.; Naheed, S.; Adhikari, A.; Awalia, J.J.A. Bio-Active Antioxidants from Plant Foods for Neutraceutical Product Development. U.S. Patent 13/759, 26 June 2018.

3. Halpin, H.A.; Morales-Suárez-Varela, M.M.; Martin-Moreno, J.M. Chronic disease prevention and the new public health. Public Health Rev. 2010, 32, 120-154. [CrossRef]

4. Ullah, W.; Uddin, G.; Siddiqui, B.S. Ethnic uses, pharmacological and phytochemical profile of genus Grewia. J. Asian Nat. Prod. Res. 2012, 14, 186-195. [CrossRef]

5. Kirtikar, K.R.; Basu, B.D. Indian Medicinal Plants; Periodical Expert's Book Agency: New Delhi, India, 1991; 1028p.

6. Louppe, A.A.; Oteng-Amoako, A.A.; Brink, M. Plant Resources of Tropical Africa 7(1); PROTA Foundation: Wageningen, The Netherlands, 2008.

7. Rajan, M.D.; Sarumathy, K.; Palani, S.; Sakthivel, K.; Vijay, T. Phytochemical studies by GC-MS and cardioprotective effect of Grewia hirsute (gh) on doxorubicin induced cardiotoxicity in albino rats. Int. J. Univers. Pharm. Bio Sci. 2011, 1, 1-18.

8. Sharma, N.; Patni, V. Comparative analysis of total flavonoids, quercetin content and antioxidant activity of in vivo and in vitro plant parts of Grewia asiatica Mast. Int. J. Pharm. Pharm. Res. 2013, 5, 464-469.

9. Shetty, B.V.; Vijendra, S. Flora of Rajasthan; Botanical Survey of India: Calcutta, India, 1987; Volume 1.

10. Singh, N.; Irchhaiya, R.; Dudhe, R.; Kumar, S. Phytochemical screening and immunomodulator activity of Grewia asiatica Linn. leaves. J. Adv. Sci. Res. 2019, 10, 166-171.

11. Paul, S.; Sharma, S.; Paliwal, S.K.; Kasture, S.B. Protective action of Grewia asiatica (phalsa) berries against scopolamine-induced deficit in learning and memory using behavior paradigms in rats. Adv. Tradit. Med. 2019, 20, 243-253. [CrossRef]

12. Joy, M.K.I.; Akhter, N.; Reza, R.; Antara, M.S.R.; Islam, M.S.; de la Cruz, C.V.; Ismal, M.R. Ex-vivo acetylcholinesterase and butyrylcholinesterase inhibitory activities assay of G. asiatica and G. tiliaefolia (Tiliaceae) Leaves. Annu. Res. Rev. Biol. $2019,34,1-10$.

13. Koley, T.K.; Khan, Z.; Oulkar, D.; Singh, B.; Bhatt, B.P.; Banerjee, K. Profiling of polyphenols in phalsa (Grewia asiatica L.) fruits based on liquid chromatography high resolution mass spectrometry. J. Food Sci Technol. 2020, 57, 606-616. [CrossRef]

14. Bari, W.U.; Zahoor, M.; Zeb, A.; Sahibzada, M.U.K.; Ullah, R.; Shahat, A.A.; Hafiz, M.M.; Irfan, K. Isolation, pharmacological evaluation and molecular docking studies of bioactive compounds from Grewia optiva. Drug Des. Dev. Ther. 2019, 13, 3029-3036. [CrossRef]

15. Akwu, N.; Naidoo, Y.; Singh, M.; Thimmegowda, S.C.; Nundkumar, N.; Lin, J. Isolation of lupeol from Grewia lasiocarpa stem bark: Antibacterial, antioxidant, and cytotoxicity activities. Biodivers. J. Biol. Divers. 2020, 21, 5684-5690. [CrossRef]

16. Muka, T.; Glisic, M.; Milic, J.; Verhoog, S.; Bohlius, J.; Bramer, W.; Chowdhury, R.; Franco, O.H. A 24-step guide on how to design, conduct, and successfully publish a systematic review and meta-analysis in medical research. Eur. J. Epidemiol. 2019, 35, 49-60. [CrossRef]

17. Acedo, F.J.; Barroso, C.; Casanueva, C.; Galan, J.L. Co-authorship in management and organizational studies: An empirical and network analysis. J. Manag. Stud. 2006, 43, 957-983. [CrossRef]

18. Cisneros, L.; Ibanescu, M.; Keen, C.; Lobato-Calleros, O.; Niebla-Zatarain, J. Bibliometric study of family business succession between 1939 and 2017: Mapping and analyzing authors' networks. Scientometrics 2018, 117, 919-951. [CrossRef]

19. Jan van Eck, N.; Waltman, L. VOS Viewer Manual. 2019. Available online: https://www.vosviewer.com/documentation/ Manual_VOSviewer_1.6.10.pdf (accessed on 12 December 2021).

20. Newman, N.M.J. Coauthorship networks and patterns of scientific collaboration. Proc. Natl. Acad. Sci. USA 2004, 101, 5200-5205. [CrossRef] [PubMed]

21. Chattopadhyay, S.; Pakrashi, S.C. Studies on Indian medicinal-plants. 34. Triterpenes from Grewia asiatica. J. Indian Chem. Soc. $1975,52,553$.

22. Ahamed, M.B.K.; Krishna, V.; Dandin, C.J. In vitro antioxidant and in vivo prophylactic effects of two $\gamma$-lactones isolated from Grewia tiliaefolia against hepatotoxicity in carbon tetrachloride intoxicated rats. Eur. J. Pharmacol. 2010, 631, 42-52. [CrossRef]

23. Natarajan, A.; Sugumar, S.; Bitragunta, S.; Balasubramanyan, N. Molecular docking studies of (4 Z, 12 Z)-cyclopentadeca-4, 12-dienone from Grewia hirsuta with some targets related to type 2 diabetes. BMC Complement Altern. Med. 2015, 15, 73. [CrossRef]

24. Qamar, M.; Akhtar, S.; Ismail, T.; Sestili, P.; Tawab, A.; Ahmed, N. Anticancer and anti-inflammatory perspectives of Pakistan's indigenous berry Grewia asiatica Linn (Phalsa). J. Berry Res. 2020, 10, 115-131. [CrossRef]

25. Ul Bari, W.; Rehman, N.U.; Khan, A.; Ahsan Halim, S.; Yuan, Y.; Blaskovich, M.A.; Ziora, M.Z. Bio-potency and molecular docking studies of isolated compounds from Grewia optiva JR Drumm. ex Burret. Molecules 2021, 26, 2019. [CrossRef]

26. Talpur, M.K.; Talpur, F.N.; Balouch, A. Analysis and characterization of anthocyanin from phalsa (grewia asiatica). MOJ Food Process. Technol. 2017, 5, 299-305. [CrossRef] 
27. Iftikhar, M.; Zahoor, M.; Naz, S.; Nazir, N.; Batiha, G.E.S.; Ullah, R.; Bari, A.; Hanif, M.; Mahmood, H.M. Green synthesis of silver nanoparticles using Grewia optiva leaf aqueous extract and isolated compounds as reducing agent and their biological activities. J. Nanomater. 2020, 2020, 8949674. [CrossRef]

28. Abou Zeid, A.H.S.; Sleem, A.A. Anti-hyperlipidemic effect and lipoidal constituents of Grewia asiatica L. leaves. Bull. Natl. Res. Cent. 2005, 30, 557-573.

29. Lakshmi, V.; Chauhan, J.S. Grewinol a keto-alcohol from the flowers of Grewia asiatica [Drug plant]. Lloydia 1976, 39, 372-374.

30. Gupta, P.; Bhatnagar, I.; Kim, S.K.; Verma, A.K.; Sharma, A. In-vitro cancer cell cytotoxicity and alpha amylase inhibition effect of seven tropical fruit residues. Asian Pac. J. Trop. Biomed. 2014, 4, 665-671. [CrossRef]

31. Yadav, A.K. Phalsa: A Potential New Small Fruit for Georgia. In Perspectives on New Crops and New Uses; ASHS Press: Alexandria, VA, Canada, 1999; pp. 348-352.

32. Pundlik, S.P.P. The study on proximate composition of different species of Genus Grewia from western Maharashtra. Eur. J. Mol. Clin. Med. 2021, 7, 3919-3924.

33. Zia-Ul-Haq, M.; Ahmad, S.; Imran, I.; Ercisli, S.; Moga, M. Compositional study and antioxidant capacity of Grewia asiatica L. seeds grown in Pakistan. Comptes Rendus Acad. Bulg. Sci. 2015, 68, 191-200.

34. Elhassan, G.M.; Yagi, S.M. Nutritional composition of Grewia species (Grewia tenax (Forsk.) Fiori, G. flavescens Juss and G. villosa Willd) fruits. Adv. J. Food Sci Technol. 2010, 2, 159-162.

35. Abdualrahman, M.A.Y.; Ali, A.O.; Suliman, A. Nutritional evaluation of Guddaim fruits (Grewia tenax) and its utilization in ice cream production. Sudan J. Sci. Technol. 2011, 12, 38-43.

36. Nyakudya, T.T.; Nosenga, N.; Chivandi, E.; Erlwanger, K.H.; Gundidza, M.; Gundidza, E.; Muredzi, P. Grewia bicolor seed oil: Putative pharmaceutical, cosmetic and industrial uses. South Afr. J. Bot. 2015, 97, 154-158. [CrossRef]

37. Joshi, A.; Bhobe, M.; Sattarkar, A. Phytochemical investigation of the roots of Grewia microcos Linn. J. Chem. Pharm. 2013, 5, 80-87.

38. Bala, K.; Barmanray, A. Bioactive compounds, vitamins and minerals composition of freeze-dried Grewia asiatica L. (phalsa) pulp and seed powder. Asian J. Dairy Food Res. 2019, 38, 237-241.

39. Khan, A.S.; Hussain, A.; Khan, F. Nutritional importance of micronutrients in some edible wild and unconventional fruits. J. Chem. Soc. Pak. 2006, 28, 576-582.

40. Liu, X.; Dong, M.; Chen, X.; Jiang, M.; Lv, X.; Yan, G. Antioxidant activity and phenolics of an endophytic Xylaria sp. from Ginkgo biloba. Food Chem. 2007, 105, 548-554. [CrossRef]

41. Ali, S.I.; Khan, N.A.; Husain, I. Flavonoid constituents of Grewia asiatica. J. Sci. Res. 1982, 4, 55-56.

42. Lakshmi, V.; Agarwal, S.K.; Chauhan, J.S. A new $\delta$-lactone from the flowers of Grewia asiatica. Phytochemistry 1976, 15, 1397-1399. [CrossRef]

43. Li, Y.; Kong, D.; Fu, Y.; Sussman, M.R.; Wu, H. The effect of developmental and environmental factors on secondary metabolites in medicinal plants. Plant Physiol. Biochem. 2020, 148, 80-89. [CrossRef]

44. Khan, R.S.; Asghar, W.; Khalid, N.; Nazir, W.; Farooq, M.; Ahmed, I.; Syed, Q.A. Phalsa (Grewia asiatica L.) fruit berry a promising functional food ingredient: A comprehensive review. J. Berry Res. 2019, 9, 179-193. [CrossRef]

45. Kumar, S.; Kumar, D. Antioxidant and free radical scavenging activities of edible weeds. Afr. J. Food Agric. Nutr. Dev. 2009, 9, 1174-1187. [CrossRef]

46. Gupta, M.K.; Lagarkha, R.; Sharma, D.K.; Sharma, P.K.; Singh, R.; Ansari, H.S. Antioxidant activity of the successive extracts of Grewia asiatica leaves. Chem. Asian J. 2007, 19, 3417.

47. Asghar, M.N.; Khan, I.U.; Sherin, L.; Ashfaq, M. Evaulation of antioxidant activity of Grewia asiatica berry using 2,2'-azinobis(3-ethylbenzothiazoline-6-sulphonic acid) and N, N-dimethyl-p-phenylenediamine radical cations decolourization assays. Chem. Asian J. 2008, 20, 5123.

48. Siddiqi, R.; Naz, S.; Sayeed, S.A.; Ishteyaque, S.; Haider, M.S.; Tarar, O.M.; Jamil, K. Antioxidant potential of the polyphenolics in Grewia asiatica, Eugenia jambolana and Carissa carandas. J. Agric. Sci. 2013, 5, 217-223. [CrossRef]

49. Srivastava, J.; Kumar, S.; Vankar, P.S. Correlation of antioxidant activity and phytochemical profile in native plants. Nutr. Food Sci. 2012, 42, 71-79. [CrossRef]

50. Imran, I.; Javaid, S.; Waheed, A.; Rasool, M.F.; Majeed, A.; Samad, N.; Saeed, H.; Alqahtani, F.; Ahmed, M.M.; Alaqil, F.A. Grewia asiatica berry juice diminishes anxiety, depression, and scopolamine-induced learning and memory impairment in behavioral experimental animal models. Front. Nutr. 2020, 7, 587367. [CrossRef]

51. Goswami, S.; Jain, R.; Masih, H. Comparative evaluation of In vitro antioxidant analysis of various leaves extracts for selected medicinal plants. J. Pharmacogn. Phytochem. 2018, 7, 1477-1481.

52. Masisi, K.; Masamba, R.; Lashani, K.; Li, C.; Kwape, T.E.; Gaobotse, G. Antioxidant, cytotoxicity and cytoprotective potential of extracts of Grewia flava and Grewia bicolor Berries. J. Pharmacopunct. 2021, 24, 24-31. [CrossRef]

53. Ngonda, F. In-vitro anti-oxidant activity and free radical scavenging potential of roots of Malawian Trichodesma zeylanicumm (burm. F.). Asian J. Biomed. Pharm. Sci. 2013, 3, 21-25.

54. Yen, G.C.; Chen, H.Y. Antioxidant activity of various tea extracts in relation to their antimutagenicity. J. Agric. Food Chem. 1995, 43, 27-32. [CrossRef]

55. Marya, B.; Dattani, K.H.; Patel, D.D.; Patel, P.D.; Patel, D.; Suthar, M.P.; Patel, V.P.; Bothara, S.B. In vitro cytotoxicity evaluation of aqueous fruit and leaf extracts of Grewia asiatica using MTT assay. Pharma Chem. 2011, 3, 282-287. 
56. Dattani, K.H.; Patel, D.D.; Marya, B.; Patel, P.D.; Patel, D.; Suthar, M.P.; Patel, V.P.; Bothara, S.B. In-vitro cytotoxicity evaluation of methanolic fruit extract of Grewia asiatica using MTT assay. Inventi Impact Ethnopharmacol. 2011, 2011, $282-287$.

57. Kakoti, B.B.; Selvan, V.T.; Manikandan, L.; Gupta, M.; Mazumder, U.K.; Das, B. Antitumor and in-vitro activity of Grewia asiatica Linn.against Ehlrich's ascites carcinoma cell lines. Pharmacol. Online 2011, 3, 956-960.

58. Das, S.; Das, S.; De, B. In vitro inhibition of key enzymes related to diabetes by the aqueous extracts of some fruits of West Bengal India. Curr. Nutr. Food Sci. 2012, 8, 19-24.

59. Akhtar, B.; Ashraf, M.; Javeed, A.; Sharif, A.; Akhtar, M.F.; Saleem, A.; Murtaza, G. Analgesic, antipyretic and antiinflammatory activities of Grewia asiatica fruit extracts in albino mice. Acta Pol. Pharm._Drug Res. 2016, 73, 983-989.

60. Paviaya, U.S.; Kumar, P.; Wanjari, M.M.; Thenmozhi, S.; Balakrishnan, B.R. Analgesic and anti-inflammatory activity of root bark of Grewia asiatica Linn. in rodents. Anc. Sci. Life. 2013, 32, 150-155. [CrossRef] [PubMed]

61. Bajpai, S.; Hussain, T.; Pathak, R.; Hussain, A. Evaluation of anti-inflammatory activity of Grewia asiatica methanolic fruit extract in Wistar rats. Asian Pac. J. Trop. Biomed. 2012, 10,1-4.

62. Khanal, D.P.; Raut, B.; Kafle, M. A comparative study on phytochemical and biological activities of two Grewia species. J. Manmohan Meml. Inst. Health Sci. 2016, 2, 53-60. [CrossRef]

63. Zia-Ul-Haq, M.; Ahmad, M.; Mehjabeen, J.N.; Ahmad, S.; Qayum, M.; Marwat, I.K. Antimicrobial screening of selected flora of Pakistan. Arch. Biol. Sci. 2011, 63, 691-695. [CrossRef]

64. Siddiqi, R.; Naz, S.; Ahmad, S.; Sayeed, S.A. Antimicrobial activity of the polyphenolic fractions derived from Grewia asiatica, Eugenia jambolana and Carissa carandas. Int. J. Food Sci. Technol. 2011, 46, 250-256. [CrossRef]

65. Israr, F.; Hassan, F.; Naqvi, B.S.; Azhar, I.; Jabeen, S.; Hasan, S.M.F. Studies on antibacterial activity of some traditional medicinal plants used in folk medicine. Pak. J. Pharm. Sci. 2012, 25, 669-674.

66. Akhtar, N.; Mirza, B. Phytochemical analysis and comprehensive evaluation of antimicrobial and antioxidant properties of 61 medicinal plant species. Arab. J. Chem. 2018, 11, 1223-1235. [CrossRef]

67. Kature, D.; Gupta, G.; Gilotra, R. Phytochemical Investigation \& Antibacterial Activity of Hydroethanolic Leaf Extract of Grewia Hirsuta Collected from Forest. SGVU J. Pharm. Res. Educ. 2020, 5, 423-431.

68. Dawar, S.H.A.H.N.A.Z.; Hanif, A.S.M.A.; Siddique, R. Management of root rot fungi by Grewia asiatica L. leaves and on the growth of crop plants. Pak. J. Bot. 2020, 52, 469-476. [CrossRef]

69. Khattab, H.A.; El-Shitany, N.A.; Abdallah, I.Z.; Yousef, F.M.; Alkreathy, H.M. Antihyperglycemic potential of Grewia asiatica fruit extract against streptozotocin-induced hyperglycemia in rats: Anti-inflammatory and antioxidant mechanisms. Oxid. Med. Cell. Longev. 2015, 2015, 549743. [CrossRef]

70. Patil, P.; Patel, M.M.; Bhavsar, C.J. Preliminary phytochemical and hypoglycemic activity of leaves of Grewia asiatica L. Res. J. Pharm. Biol. Chem. Sci. 2011, 2, 516-520.

71. Zia-Ul-Haq, M.; Shahid, S.A.; Muhammed, S.; Qayum, M.; Khan, I.; Ahmad, S. Antimalarial, antiemetic and antidiabetic potential of Grewia asiatica L. leaves. J. Med. Plant. Res. 2012, 6, 3087-3092.

72. Das, D.; Mitra, A.; Datta, D.; Saha, A.; Hazra, J. Evaluation of antipyretic and analgesic activity of parusaka (Grewia asiatica Linn.): An indigenous Indian plant. Int. J. Res. Ayurveda Pharm. 2012, 3, 519-523.

73. Mesaik, M.A.; Ahmed, A.; Khalid, A.S.; Jan, S.; Siddiqui, A.A.; Perveen, S.; Azim, M.K. Effect of Grewia asiatica fruit on Glycemic index and phagocytosis tested in healthy human subjects. Pak. J. Pharm. Sci. 2013, 26, 85-89. [PubMed]

74. Sisodia, R.; Singh, S.; Sharma, K.V.; Ahaskar, M. Post treatment effect of Grewia asiatica against radiation-induced biochemical alterations in Swiss albino mice. J. Environ. Pathol. Toxicol. 2008, 27, 113-121. [CrossRef]

75. Sharma, K.V.; Sisodia, R. Hepatoprotective efficacy of Grewia asiatica fruit against oxidative stress in swiss albino mice. Int. J. Radiat. Res. 2010, 8, 175.

76. Al-Dhabi, N.A.; Ghilan, A.K.M.; Esmail, G.A.; Arasu, M.V.; Duraipandiyan, V.; Ponmurugan, K. Bioactivity assessment of the Saudi Arabian Marine Streptomyces sp. Al-Dhabi-90, metabolic profiling and its in vitro inhibitory property against multidrug resistant and extended-spectrum beta-lactamase clinical bacterial pathogens. J. Infect. Public Health 2019, 12, 549-556. [CrossRef]

77. Dixon, R.A.; Howles, P.A.; Lamb, C.; He, X.Z.; Reddy, J.T. Prospects for the metabolic engineering of bioactive flavonoids and related phenylpropanoid compounds. Adv. Exp. Med. Biol. 1998, 439, 55-66.

78. Siegel, R.L.; Miller, K.D.; Jemal, A. Cancer statistics. CA Cancer J. Clin. 2019, 69, 7-34. [CrossRef] [PubMed]

79. Segovia-Siapco, G.; Sabaté, J. Health and sustainability outcomes of vegetarian dietary patterns: A revisit of the EPIC-Oxford and the Adventist Health Study-2 cohorts. Eur. J. Clin. Nutr. 2018, 72, 60-70. [CrossRef] [PubMed]

80. Catanzaro, E.; Calcabrini, C.; Turrini, E.; Sestili, P.; Fimognari, C. Nrf2: A potential therapeutic target for naturally occurring anticancer drugs? Expert Opin. Ther. Targets 2017, 21, 781-793. [CrossRef] [PubMed]

81. Ismail, T.; Calcabrini, C.; Diaz, A.; Fimognari, C.; Turrini, E.; Catanzaro, E.; Sestili, P. Ellagitannins in cancer chemoprevention and therapy. Toxins 2016, 8, 151. [CrossRef] [PubMed]

82. Parveen, A.; Irfan, M.; Jilani, M.S.; Wasim, K.; Kiran, M.; Muhammad, F. Lack of brine shrimp lethality and hemagglutination activity in Grewia asiatica Linn. Pharm. Negat. Results 2013, 4, 1-4. [CrossRef]

83. Krebs, E.E.; Kroenke, K.; Wu, J.; Bair, M.J.; Kozak, M.A.; Yu, Z. Opioid use as a predictor of health care use and pain outcomes: Analysis of clinical trial data. Pain Med. 2016, 17, 1261-1268. [CrossRef] [PubMed]

84. Zarei, M.; Mohammadi, S.; Abolhassani, N.; Asgari, N.M. The antinociceptive effects of hydroalcoholic extract of Bryonia dioica in male rats. Avicenna J. Neuro Psycho Physiol. 2015, 2, e25761. [CrossRef] 
85. Rodriguez, V.L.; Davoudian, T. Clinical measurement of pain, opioid addiction, and functional status. In Treating Comorbid Opioid Use Disorder in Chronic Pain; Springer International Publishing: Cham, Switzerland, 2016; pp. 47-56.

86. Kazemi, S.; Shirzad, H.; Rafieian-Kopaei, M. Recent findings in molecular basis of inflammation and anti-inflammatory plants. Curr. Pharm. Des. 2018, 24, 1551-1562. [CrossRef]

87. Unnikrishnan, R.; Pradeepa, R.; Joshi, S.R.; Mohan, V. Type 2 diabetes: Demystifying the global epidemic. Diabetes 2017, 66, 1432-1442. [CrossRef]

88. Herman, W.H. The global burden of diabetes: An overview. In Diabetes Mellitus in Developing Countries and Underserved Communities; Springer International Publishing: Cham, Switzerland, 2017; pp. 1-5.

89. Khatune, N.A.; Rahman, B.M.; Barman, R.K.; Wahed, M.I.I. Antidiabetic, antihyperlipidemic and antioxidant properties of ethanol extract of Grewia asiatica Linn. bark in alloxan-induced diabetic rats. BMC Complement. Altern. Med. 2016, 16, 295. [CrossRef]

90. Latif, K.A.A.; Prasad, A.K.; Kumar, S.; Iyer, S.V.; Patel, H.A.; Patel, J.A. Comparative antidiabetic studies of leaves of Ipomoea carnea and Grewia asiatica on streptozotocin induced diabetic rats. Int. J. Pharm. Biol. Arch. 2012, 3, 853-857.

91. Ahaskar, M.; Sisodia, R. Modulation of radiation induced biochemical changes in brain of swiss albino mice by Grewia asiatica. Asian J. Exp. Biol. Sci. 2006, 20, 399-404.

92. Ahaskar, M.; Sharma, K.V.; Singh, S.; Sisodia, R. Radioprotective effect of fruit extract of Grewia asiatica in Swiss albino mice against lethal dose of $\gamma$-irradiation. Asian J. Exp. Sci. 2007, 21, 295-308.

93. Sisodia, R.; Singh, S. Biochemical, behavioural and quantitative alterations in cerebellum of Swiss albino mice following irradiation and its modulation by Grewia asiatica. Int. J. Radiat. Biol. 2009, 85, 787-795. [CrossRef] [PubMed]

94. Singh, S.; Sharma, K.V.; Sisodia, R. Radioprotective role of Grewia asiatica in mice blood. Pharmacol. Online 2007, 2, 32-43.

95. Sisodia, R.; Ahaskar, M.; Sharma, K.V.; Singh, S. Modulation of radiation-induced biochemical changes in cerebrum of Swiss albino mice by Grewia asiatica. Acta Neurobiol. Exp. 2008, 68, 32.

96. Sharma, K.V.; Sisodia, R. Evaluation of the free radical scavenging activity and radioprotective efficacy of Grewia asiatica fruit. J. Radiol. Prot. 2009, 29, 429. [CrossRef]

97. Arasu, M.V.; Arokiyaraj, S.; Viayaraghavan, P.; Kumar, T.S.J.; Duraipandiyan, V.; Al-Dhabi, N.A.; Kavaiyarasu, K. One step green synthesis of larvicidal, and azo dye degrading antibacterial nanoparticles by response surface methodology. J. Photochem. Photobiol. 2019, 190, 154-162. [CrossRef] [PubMed]

98. Valsalam, S.; Agastian, P.; Arasu, M.V.; Al-Dhabi, N.A.; Ghilan, A.K.M.; Kaviyarasu, K.; Arokiyaraj, S. Rapid biosynthesis and characterization of silver nanoparticles from the leaf extract of Tropaeolum majus L. and its enhanced in-vitro antibacterial, antifungal, antioxidant and anticancer properties. J. Photochem. Photobiol. B Biol. 2019, 191, 65-74. [CrossRef]

99. Mulaudzi, R.B.; Ndhlala, A.R.; Kulkarni, M.G.; Finnie, J.F.; Van Staden, J. Antimicrobial properties and phenolic contents of medicinal plants used by the Venda people for conditions related to venereal diseases. J. Ethnopharmacol. 2011, 135, 330-337. [CrossRef] [PubMed]

100. Sangita, K.; Avijit, M.; Shilpa, P.; Shivkanya, J. Studies of the antifungal and antiviral activity of methanolic extract of leaves of Grewia asiatica. Pharmacogn. J. 2009, 1, 221-223.

101. Yaqueen, Z.; Sohail, T.; Rahman, A.; Salim, M.; Rahman, Z. Evaluation of antiemetic activities of alcoholic extract of Grewia asiatica in experimental model dog. Pak. J. Sci. Ind. Res. 2008, 51, 212-215.

102. Zia-Ul-Haq, M.; Shahid, S.A.; Ahmed, S.; Ahmad, S.; Qayum, M.; Khan, I. Anti-platelet activity of methanolic extract of Grewia asiatica L. leaves and Terminalla chebula Retz. fruits. J. Med. Plant. Res. 2012, 6, 2029-2032.

103. Li, Y.; Yao, J.; Han, C.; Yang, J.; Chaudhry, M.T.; Wang, S.; Yin, Y. Quercetin, inflammation and immunity. Nutrients 2016, 8, 167. [CrossRef]

104. Sim, M.O.; Lee, H.I.; Ham, J.R.; Seo, K.I.; Kim, M.J.; Lee, M.K. Anti-inflammatory and antioxidant effects of umbelliferone in chronic alcohol-fed rats. Nutr. Res. Pract. 2015, 9, 364-369. [CrossRef]

105. Lv, H.; Yu, Z.; Zheng, Y.; Wang, L.; Qin, X.; Cheng, G.; Ci, X. Isovitexin exerts anti-inflammatory and anti-oxidant activities on lipopolysaccharide-induced acute lung injury by inhibiting MAPK and NF- $\mathrm{B}$ and activating HO-1/Nrf2 pathways. Int. J. Biol. Sci. 2016, 12, 72-86. [CrossRef]

106. Jia, Z.; Chen, A.; Wang, C.; He, M.; Xu, J.; Fu, H.; Zhang, X.; Lv, W.; Guo, Z. Amelioration effects of Kaempferol on immune response following chronic intermittent cold-stress. Res. Vet. Sci. 2019, 125, 390-396. [CrossRef]

107. Jebin, R.; Molla, M.I.; Chowdhury, S.M.; Rafe, M.R. Antidepressant and sedative-hypnotic activities of methanolic extract of Grewia asiatica Linn. leaves in mice. Bangladesh Pharm. J. 2019, 22, 185-191. [CrossRef]

108. Gupta, N.; Kulkarni, G.T.; Kumar, P.; Awasthi, R. Grewia asiatica Mucilage: A smart gelling polymeric material for pharmaceutical applications in vitro studies. Curr. Mater. Sci. Former. Recent Pat. Mater. Sci. 2019, 12, 117-126. [CrossRef]

109. Institute of Medicine. Dietary Reference Intakes for Calcium and Vitamin D; The National Academies Press: Washington, DC, USA, 2011.

110. Trumbo, P.; Yates, A.A.; Schlicker, S.; Poos, M. Dietary reference intakes: Vitamin A, vitamin K, arsenic, boron, chromium, copper, iodine, iron, manganese, molybdenum, nickel, silicon, vanadium, and zinc. J. Am. Diet. Assoc. 2001, 101, 294-301. [CrossRef]

111. The US Food and Nutrition Board. Dietary Reference Intakes for Vitamin C, Vitamin E, Selenium, and Carotenoids; Institute of Medicine Washington (DC); National Academy Press: Washington, DC, USA, 2000.

112. Deruelle, F.; Baron, B. Vitamin C: Is supplementation necessary for optimal health? J. Altern Complement. Med. 2008, 14, 1291-1298. [CrossRef] [PubMed] 
113. National Research Council. Potassium. In Mineral Tolerance of Animals, 2nd ed.; National Academies Press: Washington, DC, USA, 2005; pp. 306-320.

114. Preuss, H.G. Electrolytes: Sodium, chloride, and potassium. In Present Knowledge in Nutrition, 9th ed.; Bowman, B.A., Russell, R.M., Eds.; LSI Press: Washington, DC, USA, 2006; Volume I, pp. 409-421.ss.

115. Kang, M.J.; Shin, M.S.; Park, J.N.; Lee, S.S. The effects of polyunsaturated: Saturated fatty acids ratios and peroxidisability index values of dietary fats on serum lipid profiles and hepatic enzyme activities in rats. Br. J. Nutr. 2005, 94, 526-532. [CrossRef]

116. Salter, A.M. Dietary fatty acids and cardiovascular disease. Animal 2013, 7, 163-171. [CrossRef] [PubMed]

117. Connor, W.E. Harbingers of coronary heart disease: Dietary saturated fatty acids and cholesterol. Is chocolate benign because of its stearic acid content? Am. J. Clin. Nutr. 1999, 70, 951-952. [CrossRef]

118. Hu, F.B.; Manson, J.E.; Willett, W.C. Types of dietary fat and risk of coronary heart disease: A critical review. J. Am. Coll. Nutr. 2001, 20, 5-19. [CrossRef] [PubMed]

119. Beeharry, N.; Lowe, J.E.; Hernandez, A.R.; Chambers, J.A.; Fucassi, F.; Cragg, P.J. Linoleic acid and antioxidants protect against DNA damage and apoptosis induced by palmitic acid. Mutat. Res./Fundam. Mol. Mech. Mutagenesis 2003, 530, 27-33. [CrossRef]

120. Kris-Etherton, P.M. Monounsaturated fatty acids and risk of cardiovascular disease. Circulation 1999, 100, 1253-1258. [CrossRef]

121. Menendez, J.A.; Vellon, L.; Colomer, R.; Lupu, R. Oleic acid, the main monounsaturated fatty acid of olive oil, suppresses Her-2/neu (erbB-2) expression and synergistically enhances the growth inhibitory effects of trastuzumab (Herceptin ${ }^{\mathrm{TM}}$ ) in breast cancer cells with Her-2/neu oncogene amplification. Ann. Oncol. 2005, 16, 359-371. [CrossRef] [PubMed]

122. Zambon, A.; Sartore, G.; Passera, D.; Francini-Pesenti, F.; Bassi, A.; Basso, C.; Crepaldi, G. Effects of hypocaloric dietary treatment enriched in oleic acid on LDL and HDL subclass distribution in mildly obese women. J. Intern. Med. 1999, 246, 191-201. [CrossRef]

123. Le Son, H.; Anh, N.P. Phytochemical composition, in vitro antioxidant and anticancer activities of quercetin from methanol extract of Asparagus cochinchinensis (Lour.) Merr. tuber. J. Med. Plant. Res. 2013, 7, 3360-3366.

124. Jung, H.A.; Park, J.C.; Chung, H.Y.; Kim, J.; Choi, J.S. Antioxidant flavonoids and chlorogenic acid from the leaves of Eriobotrya japonica. Arch. Pharm. Res. 1999, 22, 213-218. [CrossRef] [PubMed]

125. Guleria, S.; Tiku, A.K.; Singh, G.; Koul, A.; Gupta, S.; Rana, S. In vitro antioxidant activity and phenolic contents in methanol extracts from medicinal plants. J. Plant Biochem. Biotechnol. 2013, 22, 9-15. [CrossRef]

126. Zhang, J.; Melton, L.D.; Adaim, A.; Skinner, M.A. Cytoprotective effects of polyphenolics on H 2 O 2 -induced cell death in SH-SY5Y cells in relation to their antioxidant activities. Eur. Food Res. Technol. 2008, 228, 123-131. [CrossRef]

127. Rotelli, A.E.; Guardia, T.; Juárez, A.O.; De la Rocha, N.E.; Pelzer, L.E. Comparative study of flavonoids in experimental models of inflammation. Pharmacol. Res. 2003, 48, 601-606. [CrossRef]

128. Yonathan, M.; Asres, K.; Assefa, A.; Bucar, F. In vivo anti-inflammatory and anti-nociceptive activities of Cheilanthes farinosa. J. Ethnopharmacol. 2006, 108, 462-470. [CrossRef]

129. Nardi, G.M.; Felippi, R.; DalBó, S.; Siqueira-Junior, J.M.; Arruda, D.C.; Delle Monache, F. Anti-inflammatory and antioxidant effects of Croton celtidifolius bark. Phytomedicine 2003, 10, 176-184. [CrossRef]

130. Zhong, Z.; Dong, Z.; Yang, L.; Chen, X.; Gong, Z. Inhibition of proliferation of human lung cancer cells by green tea catechins is mediated by upregulation of let-7. Exp. Ther. Med. 2012, 4, 267-272. [CrossRef] [PubMed]

131. Hussain, J.; Ali, L.; Khan, A.L.; Rehman, N.U.; Jabeen, F.; Kim, J.S.; Al-Harrasi, A. Isolation and bioactivities of the flavonoids morin and morin-3-O- $\beta$-D-glucopyranoside from Acridocarpus orientalis-A wild Arabian medicinal plant. Molecules 2014, 19, 17763-17772. [CrossRef]

132. Yao, D.; Cui, H.; Zhou, S.; Guo, L. Morin inhibited lung cancer cells viability, growth, and migration by suppressing miR-135b and inducing its target CCNG2. Tumor Biol. 2017, 39, 1010428317712443. [CrossRef]

133. Demir, S.; Turan, İ.; Demir, F.; Ayazoglu Demir, E.; Aliyazicioglu, Y. Cytotoxic effect of Laurocerasus officinalis extract on human cancer cell lines. Marmara Pharm. J. 2017, 21, 121-126. [CrossRef]

134. Wang, L.; Du, H.; Chen, P. Chlorogenic acid inhibits the proliferation of human lung cancer A549 cell lines by targeting annexin A2 in vitro and in vivo. Biomed. Pharmacother. 2020, 131, 110673. [CrossRef]

135. Bai, X.; Lai, T.; Zhou, T.; Li, Y.; Li, X.; Zhang, H. In vitro antioxidant activities of phenols and oleanolic acid from mango peel and their cytotoxic effect on A549 cell line. Molecules 2018, 23, 1395. [CrossRef] [PubMed]

136. Garcia, M.D.; Ahumada, M.C.; Saenz, M.T. Cytostatic activity of some phenolic acids of Scrophularia frutescens L. var. frutescens. Z. Nat. C 1998, 53, 1093-1095. [CrossRef]

137. Ci, Y.; Zhang, Y.; Liu, Y.; Lu, S.; Cao, J.; Li, H.; Zhang, J.; Huang, Z.; Zhu, X.; Gao, J.; et al. Myricetin suppresses breast cancer metastasis through down-regulating the activity of matrix metalloproteinase (MMP)-2/9. Phytother Res. 2018, 32, 1373-1381. [CrossRef]

138. Rajendran, P.; Maheshwari, U.; Muthukrishnan, A.; Muthuswamy, R.; Anand, K.; Ravindran, B.; Dhanaraj, P.; Balamuralikrishnan, B.; Chang, S.W.; Chung, W.J. Myricetin: Versatile plant based flavonoid for cancer treatment by inducing cell cycle arrest and ROS-reliant mitochondria-facilitated apoptosis in A549 lung cancer cells and in silico prediction. Mol. Cell. Biochem. 2020, 476, 57-68. [CrossRef] [PubMed]

139. Jaisinghani, R.N. Antibacterial properties of quercetin. Microbiol. Res. 2017, 8, 13-14. [CrossRef]

140. Park, M.Y.; Kang, D.H. Antibacterial activity of caffeic acid combined with UV-A light against Escherichia coli O157: H7, Salmonella typhimurium, and Listeria monocytogenes. Appl. Environ. Microbiol. 2021, 87, e0063121. [CrossRef]

141. Kopacz, M.; Woznicka, E.; Gruszecka, J. Antibacterial activity of morin and its complexes with La (III), Gd (III) and Lu (III) ions. Acta Pol. Pharm. Drug Res. 2005, 62, 65-67. 